
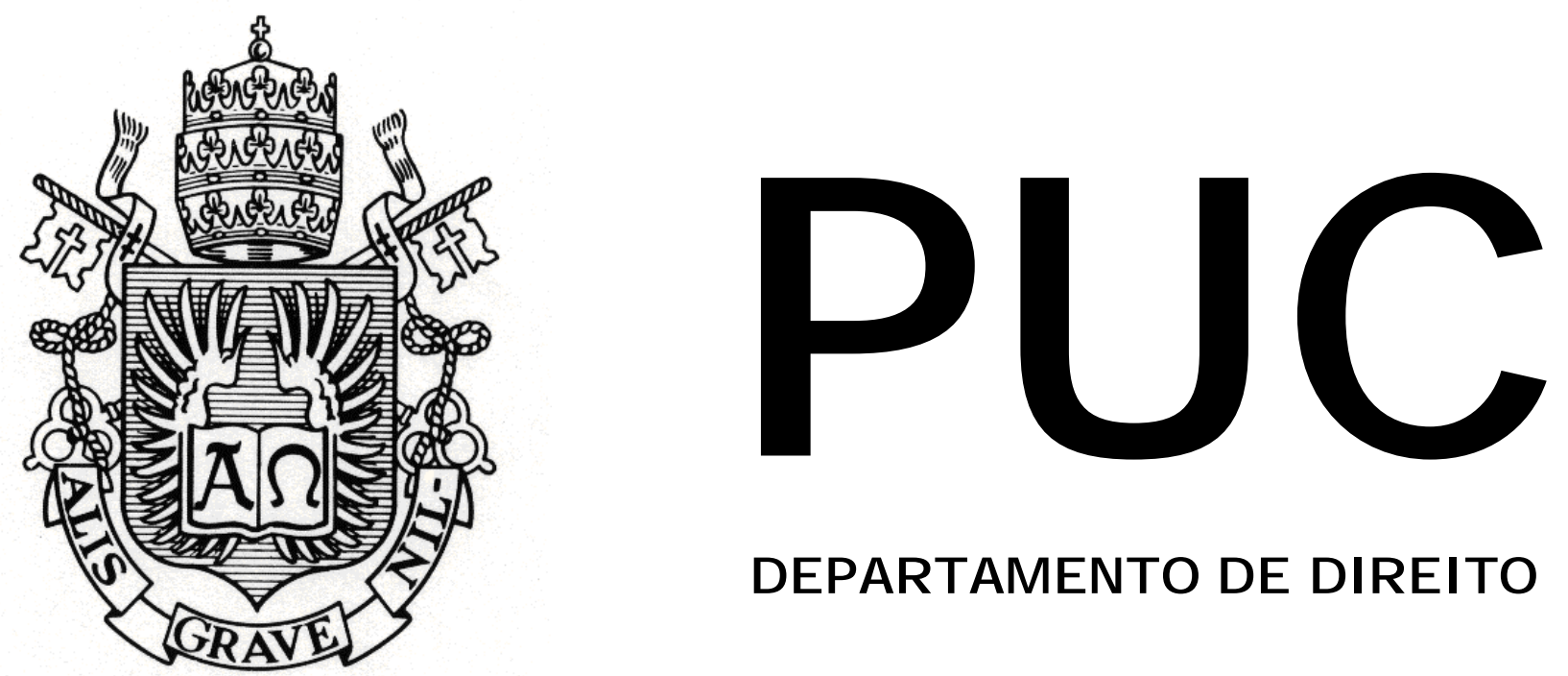

DEPARTAMENTO DE DIREITO

\title{
TIPICIDADE SOCIETÁRIA: O CONTRATO DE SOCIEDADE NO DIREITO BRASILEIRO
}

por

Fernanda Akiyo Mitsuya

ORIENTADOR: Julian Fonseca Peña Chediak

2012.2

PONTIFÍCIA UNIVERSIDADE CATÓLICA DO RIO DE JANEIRO

RUA MARQUÊS DE SÃO VICENTE, 225 - CEP 22453-900

RIO DE JANEIRO - BRASIL 


\title{
TIPICIDADE SOCIETÁRIA: \\ O CONTRATO DE SOCIEDADE NO \\ DIREITO BRASILEIRO
}

\author{
por
}

\section{Fernanda Akiyo Mitsuya}

Monografia apresentada ao Departamento de Direito da Pontifícia Universidade Católica do Rio de Janeiro (PUC-Rio) para a obtenção do Título de Bacharel em Direito.

Orientador: Julian Fonseca Peña Chediak

Coorientador: Pedro Paulo Cristofaro 


\section{Dedicatória}

Aos meus pais, por representarem o maior exemplo que eu poderia ter, por todo o carinho, por sempre exigirem o melhor de mim e pela importância que conferiram à minha formação acadêmica e profissional. Sem vocês eu não estaria aqui. 


\section{Agradecimentos}

Ao meu orientador, Julian Fonseca Peña Chediak, pelos contributivos ensinamentos na vida acadêmica e na vida profissional, pelas críticas e sugestões ao presente trabalho e pela oportunidade de ter iniciado minha carreira ao lado de profissionais extraordinários.

Ao professor Pedro Paulo Cristofaro, não só pelas contribuições a este trabalho, como também pelos ensinamentos únicos e pelo privilégio de trabalhar e aprender com uma pessoa tão experiente.

Aos demais membros do Chediak Advogados, pela compreensão, pelas oportunidades e pelo tanto que aprendi nos últimos três anos.

Aos meus familiares e amigos pelo constante incentivo, pelo carinho e pelas palavras de apoio.

A todos os professores que contribuíram para a minha formação, pela dedicação e pelo aprendizado que ficará para sempre.

Às queridas amigas da PUC, com quem tive a sorte de conviver nos últimos cinco anos e com quem pude compartilhar todas as dificuldades e alegrias ao longo da faculdade.

Por fim, um agradecimento especial ao Caio pelo apoio de sempre, por ser um grande exemplo e por toda a paciência e ajuda imensurável, sem as quais esse trabalho não teria sido o mesmo. 


\section{Resumo}

MITSUYA, FERNANDA AKIYO. Tipicidade Societária: O Contrato de Sociedade no Direito Brasileiro. Rio de Janeiro: 2012, 96 p. Monografia de final de curso. Departamento de Direito da Pontifícia Universidade Católica do Rio de Janeiro - PUC Rio.

O presente trabalho trata de um tema pouco abordado pela doutrina brasileira: a tipicidade societária. $\mathrm{O}$ fenômeno consiste na existência de um elenco taxativo de tipos societários definidos em lei, dos quais os indivíduos podem fazer uso no exercício da atividade econômica. No entanto, a questão traz diversos questionamentos, principalmente no que se refere à autonomia da vontade das partes e, em consequência, à possibilidade de se fazer uso de sociedades atípicas. Faz-se necessária, então, uma análise dos fundamentos, sobretudo jurídicos e econômicos, envolvidos na adoção de um sistema típico e em que medida são preservadas a autonomia da vontade e a liberdade de contratar. Analisandose aspectos do direito estrangeiro e a evolução do assunto no Brasil, o objetivo desta monografia é apontar as vantagens e desvantagens de um sistema típico, suas características e sua relevância para o direito societário.

\section{Palavras-chave}

Tipicidade - autonomia da vontade - tipos societários - organização sociedade - conjuntura socioeconômica - law and economics - direito estrangeiro - direito brasileiro - contrato de sociedade - taxatividade numerus clausus - atipicidade. 


\section{Índice}

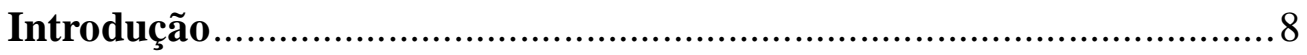

1. Principio da tipicidade ............................................................ 11

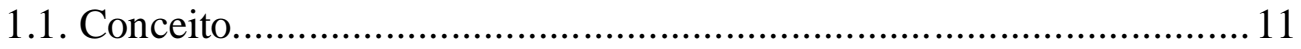

1.2. Evolução do conceito de tipo nas diversas áreas do direito ................ 14

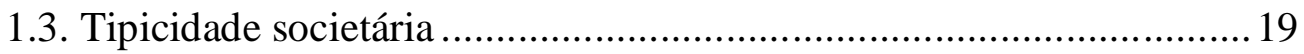

1.4. Fundamentos do princípio da tipicidade .......................................22

1.4.1. Enfoque econômico e organizacional ......................................23

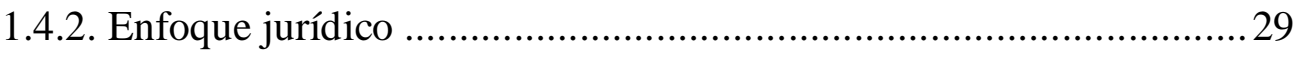

1.4.2.1. Tutela do interesse de terceiros............................................ 30

1.4.2.2. Estabilidade e equilíbrio das relações internas ........................... 33

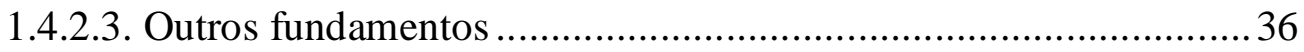

2. Principio da autonomia da vontade ........................................ 37

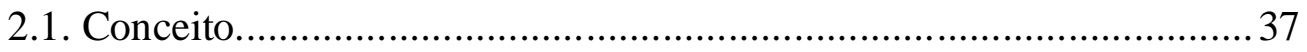

2.2. Autonomia da vontade no Código Civil de 2002 ............................... 39

2.2. Princípio da tipicidade $X$ princípio da autonomia da vontade ............ 40

3. $O$ contrato de sociedade ................................................... 45

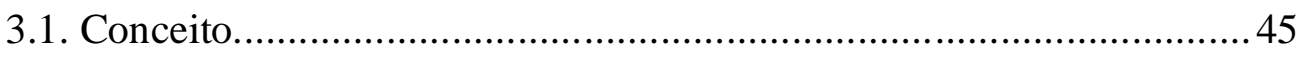

3.2. Contrato plurilateral ......................................................... 46

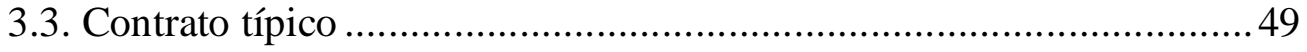

4. Características dos tipos societários...................................... 51

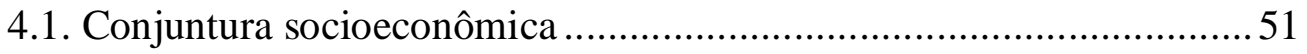

4.2. Elementos caracterizadores dos tipos .......................................5 53

5. Tipicidade societária no direito estrangeiro .............................58

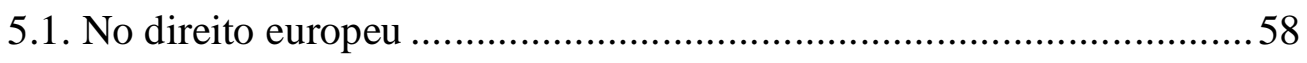




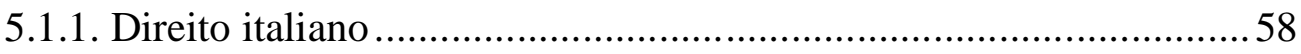

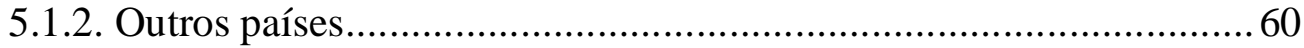

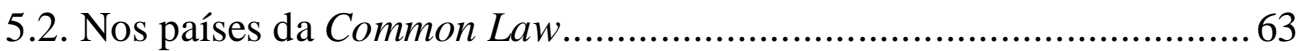

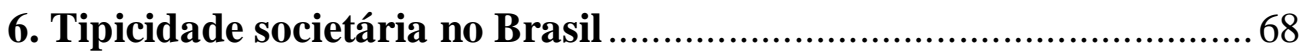

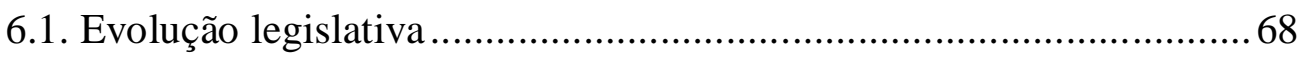

6.2. Adoção de cláusulas atípicas................................................................. 71

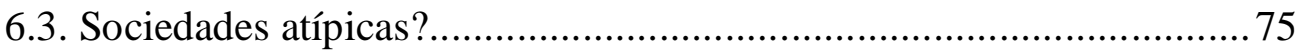

6.3.1. Um paralelo entre a sociedade atípica e a sociedade em comum.......81

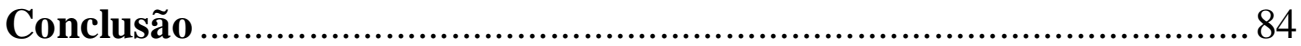

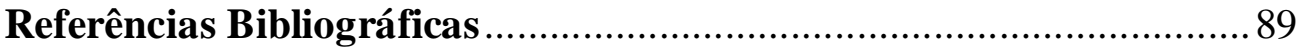




\section{Lista de abreviações}

“Codice Civile" - R.D. (Regio Decreto) n 262, de 16 março de 1942

"Código Comercial" - Lei nº 556, de 25 de junho de 1850

“Código Civil de 1916" - Lei n 3.071, de 1º de janeiro de 1916

“Código Civil de 2002" - Lei n 10.406, de 10 de janeiro de 2002

“Código de Processo Civil" - Lei nº 5.869, de 11 de janeiro de 1973.

"Lei das S.A." - Lei no 6.404, de 15 de dezembro de 1976

"Lei de Falência e Recuperação" - Lei no 11.101, de 9 de fevereiro de 2005

"STJ" - Superior Tribunal de Justiça 


\section{Introdução}

O objetivo do presente trabalho é discutir aspectos referentes ao fenômeno da tipicidade societária. Em razão da introdução de um sistema típico fechado ou numerus clausus no Código Civil de 2002, a matéria não suscita, no Brasil, grandes discussões.

Interessa, no entanto, o fato de o tema não ser tratado com tanta profundidade pelos autores brasileiros ${ }^{1}$.

Ademais, destaca-se a importância de o direito societário acompanhar o caráter dinâmico da vida em sociedade e de suas transformações políticas, econômicas e sociais. Daí a importância do estudo dos tipos societários, de suas origens e de suas contextualizações no tempo.

Nesse sentido, o presente trabalho visa explorar os aspectos por trás deste sistema aparentemente pacífico, justificando-se a adoção, no Brasil, de um sistema fechado e comparando-o com modelos de outros países, com o objetivo de se tentar concluir se o sistema brasileiro é ou não apropriado.

O trabalho é dividido em seis capítulos.

Na primeira parte, visa-se introduzir os conceitos fundamentais para o desenvolvimento da questão, abordando-se principalmente os princípios da tipicidade e da autonomia da vontade.

Quanto ao princípio da tipicidade, busca-se realizar abordagens de variadas naturezas no que se refere aos seus fundamentos, com o intuito de explorar questões que ultrapassam os aspectos jurídicos. O trabalho pretende, portanto, apresentar um lado econômico da organização em

\footnotetext{
${ }^{1}$ A despeito da referida afirmação, apesar de poucos, vale mencionar a existência de excelentes autores tratando da questão. Um ótimo exemplo é a obra da professora Rachel Sztajn, "Contrato de Sociedade e Formas Societárias", inteiramente dedicada ao tema (que, apesar de ter sido publicada anteriormente ao Código Civil de 2002, já fazia referência às disposições do projeto do novo código).
} 
sociedade, recorrendo-se, de forma breve, a autores da escola da análise econômica do direito (Law and Economics).

No que se refere ao princípio da autonomia, procura-se analisar a sua compatibilidade com o princípio da tipicidade ou se este último representa, de certa forma, uma atenuação da autonomia conferida aos particulares.

Como se verá, diversos autores entendem que o princípio da tipicidade configura, sim, certa atenuação do princípio da autonomia da vontade. No entanto, há quem entenda que a autonomia continua presente, pois os agentes possuem a opção de escolha de um dos tipos previstos em lei e, dada a existência de normas dispositivas, têm certa flexibilidade na configuração de um tipo.

No capítulo seguinte, passa-se a uma análise do contrato de sociedade, abordando-se seu conceito, sua origem e, sobretudo, suas características principais - contrato típico e plurilateral.

Em seguida, o trabalho versa sobre características específicas dos tipos societários, com a indicação de seus elementos caracterizadores e das discussões envolvidas.

Ainda nesse capítulo, trata-se da importância da conjuntura socioeconômica para a formação do tipo societário e da necessidade de sua adequação no tempo e no espaço.

Passada essa parte teórica, pretende-se demonstrar como é vista a questão da tipicidade em alguns países estrangeiros, fazendo-se breve comparação com o sistema brasileiro.

No mesmo capítulo, busca-se fazer uma interseção entre as discussões suscitadas por diversos autores de países da common law envolvendo a questão da liberdade de contratar, com a questão da tipicidade e sua eventual restrição à autonomia da vontade.

A parte final do trabalho versa sobre como se deu o desenvolvimento do fenômeno da tipicidade societária no Brasil, como funciona o sistema atual e sobre a possibilidade de se fazer uso de cláusulas atípicas e, indo ainda mais além, de sociedades atípicas. 
Aborda-se a extensão dos limites de adoção de cláusulas atípicas para a descaracterização de um tipo societário.

Por fim, também se faz um paralelo entre as sociedades atípicas e as sociedades em comum previstas no Código Civil de 2002.

São dois os principais aspectos envolvidos em toda essa discussão: de um lado, a autonomia da vontade dos agentes e a ideia da liberdade contratual como sendo essencial e, de outro, a vinculação legal a determinado tipo, sem que se possa fazer uso de um modelo não previsto.

Qual lado deve prevalecer?

A conclusão, portanto, da presente monografia, tentará responder aos seguintes questionamentos: a adoção do princípio da tipicidade societária é, de fato, a melhor opção? O uso de sociedades atípicas no Brasil é possível? Se sim, qual é o tratamento que elas devem receber? 


\section{Principio da tipicidade}

\subsection{Conceito}

Para entender o fenômeno da tipicidade societária é importante, antes de tudo, examinar o princípio da tipicidade, suas características, sua origem e a importância de sua aplicação nos diversos ramos do direito.

Como ensina JULIANA KRUEGER PELA, o pensamento tipológico é um método que consiste, basicamente, em isolar as características essenciais de determinado fenômeno complexo e multifacetado e reuni-las em esquema abstrato, considerado o tipo ${ }^{2}$.

LUIS FERNANDEZ DE LA GANDARA, autor espanhol conhecedor do assunto, ensina que o princípio da tipicidade consiste na ideia de que é reservada ao legislador, com caráter exclusivo, a faculdade de invenção de novas figuras. Segundo o autor, o catálogo legislativo de figuras societárias constitui um setor fechado, mas não imóvel ${ }^{3}$. Ele afirma que o princípio da tipicidade costuma ser examinado em relação ao problema dos limites na liberdade contratual. Essa discussão é, inclusive, objeto de enorme controvérsia, sobretudo nos países da common law, conforme se analisará adiante em capítulo referente ao direito estrangeiro.

RACHEL SZTAJN, outra referência clássica do assunto no Brasil, fazendo menção à acepção de KARL LARENZ, explica que "a noção de tipo é tomada no sentido de modelo ou estrutura, isto é, como um esquema, definido por um conjunto de regras (legais ou costumeiras) que descrevem ou definem uma estrutura negocial à qual se ligam determinados efeitos também previstos na lei ou pelo uso". ${ }^{4}$

\footnotetext{
${ }^{2}$ PELA, Juliana Krueger. As Golden Shares no Direito Brasileiro. São Paulo: Quartier Latin, 2012, p. 105.

${ }^{3}$ Veja-se a descrição de Gandara: "Este principio, cuya temática se examina tradicionalmente en relación con el problema de los limites a la libertad contractual, significa que queda reservada al legislador, con carácter exclusivo, la facultad de invención de nuevas figuras. El catálogo legislativo de figuras societarias constituye en este sentido un sector cerrado pero no inamovible". GANDARA, Luis Fernandez de la. La Atipicidad en Derecho de Sociedades. Zaragoza: Pórtico, [s.d.], p. 78.

${ }^{4}$ SZTAJN, Rachel. Contrato de Sociedade e Formas Societárias. São Paulo: Saraiva, 1989, p. 53.
} 
A autora ilustra também que:

Designa-se típico o fato de determinadas características se repetirem, de forma mais ou menos igual, sempre e quando se repetirem determinadas circunstâncias, de tal sorte que se diz ser típico aquilo que deve ser esperado segundo o curso norma (usual), aquilo que normalmente ocorre naquelas circunstâncias.

Típico significa, também, a existência, a verificação e determinação de certo número de elementos ou propriedades características que indicam ou identificam uma figura em sua totalidade e que, mesmo quando nem todos os elementos ou propriedades estejam presentes numa certa situação, permitem identificá-la com o modelo. $^{5}$

LARENZ, por sua vez, destaca que o homem precisa de modelos perfeitos para, em conformidade com eles, orientar sua ação. Ele também afirma, coerentemente, que os tipos adquirem caráter de utopias quando se afastam demasiado da realidade e não contam com o homem tal como ele tipicamente é. 6

O jurista alemão, fazendo referência a SONNENBERGER, acrescenta:

Os usos do tráfego são formas de comportamento social típico que são actuadas, em geral, pelos membros de um determinado grupo social e que se referem, imediata ou mediatamente, ao tráfego nacional. Convertem-se em normas porque a lei ou, num caso particular, um contrato para eles remetem. ${ }^{7}$

Nos dizeres de MARÍA CELIA MARSILI, “a função do tipo é a de proporcionar aos particulares uma plataforma normativa, no esquema de relações que formalizam o equilíbrio entre o poder político e o econômico, as técnicas de organicidade e imputação e os alcances que se outorga à imputação diferenciada". 8

Ao tratar da tipicidade em caráter "aberto" e "fechado", JULIANA KRUEGER PELA, fazendo referência a EMILIO BETTI, explica:

\footnotetext{
${ }^{5}$ SZTAJN, Rachel. Contrato de Sociedade e Formas Societárias. São Paulo: Saraiva, 1989, p. 10.

${ }^{6}$ LARENZ, Karl. Methodenlehre der Rechtswissenschaft (Metodologia da Ciência do Direito), $6^{\mathrm{a}}$ edição. Tradução de José Lamego, Lisboa: Fundação Calouste Gulbenkian, $3^{\text {a }}$ edição, 1997, p. 660.

${ }^{7}$ LARENZ, Karl. Methodenlehre der Rechtswissenschaft (Metodologia da Ciência do Direito), $6{ }^{\mathbf{a}}$ edição. Tradução de José Lamego, Lisboa: Fundação Calouste Gulbenkian, $3^{\text {a }}$ edição, 1997, p. 660.

8 MARSILI, María Celia. Sociedades Comerciais: el Problema de la Tipicidad. Santa Fé: Rubinzal-Culzoni, 2003, p. 67. Apud FÉRES, Marcelo Andrade. Sociedade em Comum Disciplina Jurídica e Institutos Afins. São Paulo: Editora Saraiva, 2011, p. 60.
} 
No direito privado, os tipos constroem-se, basicamente, sob duas formas.

De um lado, tem-se a tipicidade - identificada por Betti ao tratar dos negócios jurídicos - que decorre do reconhecimento, pela ordem jurídica, da relevância da função econômico-social do ato de autonomia privada. Trata-se do pensamento tipológico aplicado ao direito dos contratos, por exemplo. Para designar o resultado desse pensamento, emprega-se a expressão "tipicidade de origem social" ou "tipicidade aberta".

De outro lado, há a tipicidade imposta ab initio pela ordem jurídica, que se traduz na definição de um rol taxativo de atos considerados típicos, como ocorre nos direitos reais e no direito das sociedades. Nesse segundo caso, trata-se de fenômeno sob a rubrica de "tipicidade de origem legal" ou "tipicidade fechada".

A distinção entre tipicidade aberta e tipicidade fechada consiste, portanto, no fato de que na primeira os modelos legais servem como parâmetros, mas não constituem um rol taxativo, sendo facultada ao agente a opção de se ater ao tipo ou de livremente convencionar da forma que lhe for mais conveniente. No caso da tipicidade fechada, por outro lado, os tipos elencados pela lei são taxativos ou, em outras palavras, numerus clausus e, em consequência, as opções previstas são as únicas alternativas facultadas ao indivíduo.

Como exemplo de tipicidade aberta no direito brasileiro, conforme se verá adiante com mais detalhes, faz-se referência ao direito das obrigações e, mais especificadamente, ao dos contratos. O Código Civil de 2002 permite a celebração de contratos atípicos em seu artigo $425^{10}$ mas, ao mesmo tempo, proporciona a alternativa de se eleger um dos tipos sugeridos.

Por sua vez, a tipicidade fechada se faz presente no direito brasileiro das sociedades, a qual será o escopo do presente trabalho.

Nesse sentido, GANDARA assim explica o sistema numerus clausus:

La característica del sistema de numerus clausus no es, pues, el mantenimiento de un "arsenal" rígido de figuras, sino la imposibilidad de que los particulares

\footnotetext{
${ }^{9}$ PELA, Juliana Krueger. As Golden Shares no Direito Brasileiro. São Paulo: Quartier Latin, 2012, p. 106.

${ }^{10}$ Art. 425. É lícito às partes estipular contratos atípicos, observadas as normas gerais fixadas neste Código.
} 
puedan crear formas desconocidas al derecho positivo. A estos les está permitido únicamente elegir el modelo de operación que mejor convenga a sus necesidades pero no introducir esquemas de disciplina nuevos ${ }^{11}$.

Ainda no que se refere ao sistema da tipicidade, nota-se que cada um dos tipos é caracterizado por elementos mínimos e caracterizadores. Determinados elementos são utilizados para diferenciar e compor um determinado tipo, embora muitas vezes as definições dos tipos contenham elementos comuns.

PONTES DE MIRANDA, ao mencionar que por vezes se emprega o conteúdo de dois ou mais tipos, classifica os negócios jurídicos como sendo mistos ou típicos fracionados:

Em princípio, há auto-regramento de vontade, para se concluírem negócios jurídicos. E o número de regras jurídicas dispositivas (ius dispositivum) é considerável. Tal regulação atende à tipicidade, ou à necessidade de se não deixarem dúvidas quanto a algum ponto ou alguns pontos do conteúdo do negócio jurídico. De jeito que o próprio negócio jurídico típico dá largo ensejo para as variações de conteúdo.

Por vezes, os figurantes têm de empregar o conteúdo de dois ou mais tipos, com que alcancem o que querem, sem que tal diversidade ofenda a unidade negocial concreta. São os negócios jurídicos mistos ou negócios jurídicos típicos fracionados. A despeito da fusão, da mistura, ressalta a tipicidade. ${ }^{12}$

Assim, da diversidade de conceitos e tipos jurídicos, formam-se diversas proposições, as quais serão selecionadas pelas partes no momento de celebrarem um dado negócio concreto ${ }^{13}$.

\subsection{Evolução do conceito de tipo nas diversas áreas do direito}

Exposta a sua definição, passa-se a uma breve análise da evolução do conceito de tipo nas diversas áreas do direito.

\footnotetext{
${ }^{11}$ GANDARA, Luis Fernandez de la. La Atipicidad en Derecho de Sociedades. Zaragoza: Pórtico, [s.d.], pp. 78-79.

${ }^{12}$ MIRANDA, Pontes de. Tratado de Direito Privado. Parte Geral. São Paulo: Editora Revista dos Tribunais, $3^{a}$ edição, 1984, Tomo XXXVIII, p. 367.

${ }^{13}$ FÉRES, Marcelo Andrade. Sociedade em Comum - Disciplina Jurídica e Institutos Afins. São Paulo: Editora Saraiva, 2011, p. 55.
} 
Conforme explica MARCELO FÉRES, foi no direito penal que o tipo primeiramente se fez relevante para o direito, tendo, em um contexto garantista, se desenvolvido como forte vetor. ${ }^{14}$

No direito penal, os tipos são modelos fechados e o elenco típico é restritivo e assim deve ser mantido para preservar a sua função de garantia. $^{15}$

O mesmo ocorre no direito tributário, ramo do direito no qual, assim como no direito penal, os bens tutelados requerem rigidez para evitar arbitrariedades ou interpretações por parte da autoridade aplicadora. ${ }^{16}$

FÉRES afirma, ainda, que foi "no campo do direito público que antes se propagou a questão da tipicidade, especialmente atrelada ao princípio da legalidade". ${ }^{17}$

No direito privado, por sua vez, a tipicidade também se faz presente. É o que ocorre no caso dos direitos reais e do direito das obrigações, especialmente no que se refere à disciplina dos contratos.

No que diz respeito aos primeiros, alguns autores assemelham a tipicidade fechada das formas societárias ao elenco dos direitos reais típicos e taxativamente determinados ${ }^{18}$.

O art. 1.225 do Código Civil de $2002^{19}$ estabelece um rol taxativo de espécies de direitos reais, que devem estar sempre previstos em lei.

Isso porque, conforme explica RACHEL SZTAJN,

Caracterizam-se os direitos reais por sua oponibilidade contra todos os terceiros que se devem abster de violá-los. (...) Assim, a tipicidade dos direitos reais e dos títulos de crédito se relaciona ao princípio da oponibilidade, à obrigação de abstenção de terceiros, dentro dos limites estabelecidos em lei. Outra razão para a

\footnotetext{
${ }^{14}$ FÉRES, Marcelo Andrade. Sociedade em Comum - Disciplina Jurídica e Institutos Afins. São Paulo: Editora Saraiva, 2011, p. 53.

${ }^{15}$ SZTAJN, Rachel. Contrato de Sociedade e Formas Societárias. São Paulo: Saraiva, 1989, p. 9.

${ }^{16}$ SZTAJN, Rachel. Contrato de Sociedade e Formas Societárias. São Paulo: Saraiva, 1989, p. 13.

${ }^{17}$ FÉRES, Marcelo Andrade. Sociedade em Comum - Disciplina Jurídica e Institutos Afins. São Paulo: Editora Saraiva, 2011, p. 53.

${ }^{18}$ SZTAJN, Rachel. Contrato de Sociedade e Formas Societárias. São Paulo: Saraiva, 1989, p. 56.

19 Art. 1.225. São direitos reais: I - a propriedade; II - a superfície; III - as servidões; IV - o usufruto; V - o uso; VI - a habitação; VII - o direito do promitente comprador do imóvel; VIII - o penhor; IX - a hipoteca; X - a anticrese; XI - a concessão de uso especial para fins de moradia; XII - a concessão de direito real de uso.
} 
taxatividade do elenco é a eficácia ultra partes dos direitos reais e títulos de crédito atípicos, que deveria estar restrita apenas aos contratantes. ${ }^{20}$

Essa taxatividade dos direitos reais pode ser justificada diante da oponibilidade e da eficácia dos efeitos em relação a terceiros. Com o mesmo posicionamento, dispõe FÉRES:

A tipicidade, no caso, justifica-se pelas características dos direitos reais. A oponibilidade erga omnes e o direito de sequela, tão graves e fortes no convívio social, não poderiam ser conformados apenas pela vontade das partes. É imprescindível que a legislação atribua aos diversos tipos de direitos reais suas consequências jurídicas. ${ }^{21}$

RACHEL SZTAJN faz, inclusive, uma analogia entre os direitos reais e o contrato de sociedade:

Através de processo de analogia com os direitos reais, em razão do relevo real ou efeito real que o contrato de sociedade produz sobre os bens que são transferidos pelos sócios, além, é claro, daqueles havidos pela sociedade diretamente, pretende-se definir o elenco taxativo de tipos de formas de sociedades. ${ }^{22}$

Embora se possa afirmar que o rol dos direitos reais é taxativo e, portanto, há uma restrição de escolha pelos tipos legais, GUSTAVO TEPEDINO traz um ponto importante. O autor afirma que é preciso redimensionar a discussão já que, no âmbito do conteúdo de cada tipo, atua a autonomia privada:

Vale dizer, ao lado de regras imperativas, que definem o conteúdo de cada tipo real, convivem preceitos dispositivos, atribuídos à autonomia privada, de sorte a moldar o seu interesse à situação jurídica real pretendida. Assim, se é inegável que a constituição de um novo direito real sobre coisa alheia, ou de uma forma proprietária com características exóticas, depende do legislador, que, por sua vez, deve ater-se aos limites de utilidade social definidos pela Constituição, certo é que no âmbito do conteúdo de cada tipo real há um vasto território por onde atua a autonomia privada e que carece de controle quanto aos limites (de ordem pública) permitidos para esta atuação.

Se são verdadeiras, como parece, tais constatações, compreender-se-á que a discussão quanto ao 'numerus clausus' deve ser redimensionada, mesmo

\footnotetext{
${ }^{20}$ SZTAJN, Rachel. Contrato de Sociedade e Formas Societárias. São Paulo: Saraiva, 1989, Introdução, p. 146.

${ }^{21}$ FÉRES, Marcelo Andrade. Sociedade em Comum - Disciplina Jurídica e Institutos Afins. São Paulo: Editora Saraiva, 2011, p. 54.

${ }^{22}$ SZTAJN, Rachel. Contrato de Sociedade e Formas Societárias. São Paulo: Saraiva, 1989, Introdução, p. 57.
} 
admitindo-se, desde logo, que a reserva legal para a predisposição de uma nova figura real é inderrogável, por traduzir princípio de ordem pública.

Muito mais fértil, todavia, será perquirir, na dinâmica da atividade privada, os negócios jurídicos que, no âmbito dos tipos reais predispostos pelo Código Civil, possam ser estabelecidos sem a reprovação do sistema. Trata-se de uma série de negócios que programa, por exemplo, servidões, mútuos garantidos por cédulas rurais, locações com cláusula de vigência em caso de alienação, vendas condicionais, cujo conteúdo varia, com frequência impressionante, no curso do tempo e das relações que concretamente se estabelecem, alterando, significativamente, o conteúdo de situações reais ou de eficácia real. ${ }^{23}$

De outro lado, a ciência dos direitos obrigacionais é intrinsecamente acompanhada do princípio da autonomia da vontade e, portanto, os operadores econômicos possuem mais liberdade e poderes para regular os próprios interesses. $^{24}$

Sobre a questão da liberdade nos contratos privados, TAVARES GUERREIRO explica que "uma das mais notáveis conquistas do liberalismo econômico que imperou no século XIX e que serviu de base ao capitalismo moderno foi a afirmação do princípio da liberdade de contratar, entendido em ampla acepção". Segundo o autor:

A valorização da supremacia da vontade como fonte de direitos e obrigações representa, historicamente, a possibilidade reconhecida às partes de adotarem, em seus múltiplos relacionamentos na ordem privada, as estipulações que julgarem mais convenientes, superando os esquemas contratuais formalistas do direito anterior, derivados da tipicidade própria da tradição romana. ${ }^{25}$

No entanto, para TAVARES GUERREIRO, essa aparente liberdade sofreu uma reação de novas correntes de pensamento, tendo o direito privado acolhido restrições à autonomia da vontade, limitando a liberdade de contratar. Desta forma, foi concebida uma força normativa do Estado na economia dos contratos privados, com a edição de regras direcionadas a redimensionar a autonomia onipotente da vontade individual na criação de

\footnotetext{
${ }^{23}$ TEPEDINO, GUSTAVO. Multipropriedade Imobiliária. São Paulo: Saraiva, 1993, p. 83.

${ }^{24}$ SZTAJN, Rachel. Contrato de Sociedade e Formas Societárias. São Paulo: Saraiva, 1989, p. 14.

${ }^{25}$ GUERREIRO, José Alexandre Tavares. O Estado e a Economia dos Contratos Privados. In: Revista de Direito Mercantil Industrial, Econômico e Financeiro, vol. 31, Ano XVII, 1978, p. 77.
} 
relações jurídicas, tendo sido vedados os pactos contrários à lei e aos bons costumes e introduzidas normas específicas inderrogáveis. ${ }^{26}$

Conforme explica LARENZ, "os tipos de relações jurídicas, em especial os tipos contratuais, são tipos jurídico-estruturais surgidos na realidade jurídica, que se referem à estrutura particular de cada uma das criações jurídicas" ${ }^{27}$. Em seguida, o autor continua:

(...) a maior parte deles, tais como todos os tipos de contratos obrigacionais, devem o seu surgimento ao tráfego jurídico. O legislador regulamentou-os, porquanto os encontrou previamente na realidade da vida jurídica, apreendeu-os na sua tipicidade e adicionou-lhes a s regras que considerou adequadas para um tal tipo de contrato. Não os inventou, mas descobriu-os, porquanto não os tomou simplesmente na tradição jurídica. ${ }^{28}$

\section{CAIO MÁRIO DA SILVA PEREIRA assim explica a classificação}

dos contratos típicos e atípicos:

Diz-se que um contrato é típico (ou nominado) quando as suas regras disciplinares são deduzidas de maneira precisa nos Códigos ou nas leis. Mas a imaginação humana não estanca, pelo fato de o legislador haver deles cogitado em particular. Ao contrário, cria novos negócios, estabelece novas relações jurídicas, e então surgem outros contratos afora aqueles que recebem o batismo legislativo, ou que não foram tipificados, e por esta razão se consideram atípicos (ou inominados), (...). ${ }^{29}$

\section{Também vale recorrer à lição de ARNOLDO WALD:}

À medida que o liberalismo foi impondo suas ideias, as normas legais referentes aos contratos passaram a ter função geralmente supletiva, a não ser quando defendendo alguns princípios básicos de ordem pública, entendendo-se que, do mesmo modo que os contratantes podiam afastar a aplicação das normas dispositivas, nada impedia que criassem novas figuras contratuais, sem regulamentação legal prévia. Conhecemos, pois, hoje, no nosso direito, duas espécies de contratos: os contratos nominados ou típicos, que têm nomen iuris, ou seja, definição e estrutura provenientes da lei, e os contratos inominados ou atípicos, sem regulamentação legal apropriada.

\footnotetext{
${ }^{26}$ GUERREIRO, José Alexandre Tavares. O Estado e a Economia dos Contratos Privados. In: Revista de Direito Mercantil Industrial, Econômico e Financeiro, vol. 31, Ano XVII, 1978, pp. 77 e 78.

${ }^{27}$ LARENZ, Karl. Methodenlehre der Rechtswissenschaft (Metodologia da Ciência do Direito), $6^{\mathrm{a}}$ edição. Tradução de José Lamego, Lisboa: Fundação Calouste Gulbenkian, $3^{\text {a }}$ edição, 1997, p. 663.

${ }^{28}$ LARENZ, Karl. Methodenlehre der Rechtswissenschaft (Metodologia da Ciência do Direito), $6^{\mathrm{a}}$ edição. Tradução de José Lamego, Lisboa: Fundação Calouste Gulbenkian, $3^{\text {a }}$ edição, 1997, p. 663.

${ }^{29}$ PEREIRA, Caio Mário da Silva. Instituições de Direito Civil. Rio de Janeiro: editora Forense,

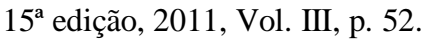


A tendência no direito se manifesta no sentido de permitir às partes a criação de número ilimitado de contratos atípicos ou inominados que somente se regulam pelos princípios gerais referentes aos contratos e, supletivamente, por normas jurídicas referentes a algum contrato típico análogo. ${ }^{30}$

Em complemento, ainda, SYLVIO RODRIGUES dispõe:

É evidente que o legislador não podia, nem pode, imaginar toda espécie de relação jurídica porventura ocorrente entre os homens, de modo a proporcionar um contrato típico para regular cada qual delas. Assim, permite que o engenho individual supra tais falhas, por meio de construções lícitas, pela elaboração de esquemas contratuais diversos das convenções nominadas. ${ }^{31}$

Como resultado, o artigo 425 do Código Civil de 2012, ao tratar da matéria, estabeleceu que é lícito às partes estipular contratos atípicos. Ou seja, é evidente que, em que pese a lei oferecer orientações tipológicas às partes, lhes é facultado contratar como melhor lhes convém, de acordo com as relações mantidas e suas particularidades, observada a prerrogativa da liberdade de contratar.

\subsection{Tipicidade societária}

Conforme visto, o fenômeno da tipicidade se faz presente em inúmeras áreas do direito. $\mathrm{O}$ foco deste trabalho, porém, será a sua presença no direito das sociedades.

No que tange sua origem, a tipicidade societária não é um fenômeno recente. Pode-se dizer que as formas organizativas tiveram sua origem na Roma antiga.

ALFREDO LAMY FILHO e JOSÉ LUIZ BULHÕES PEDREIRA, ensinam que o "fenômeno associativo, em várias de suas manifestações, sempre existiu, mas o tipo de grupo social de produção predominante na Antiguidade não requeria sistemas jurídicos próprios para a sua

\footnotetext{
${ }^{30}$ WALD, Arnoldo. Direito Civil: direito das obrigações e teoria geral dos contratos. São Paulo: Saraiva, $20^{\mathrm{a}}$ edição, 2011, vol. 2, pp. 278 e 279.

${ }^{31}$ RODRIGUES, Sylvio. Direito Civil: dos Contratos e das Declarações Unilaterais de Vontade. $28^{\text {a }}$. Edição. São Paulo: Saraiva, 2002, v. 3, p. 37. Apud FÉRES, Marcelo Andrade. Sociedade em Comum - Disciplina Jurídica e Institutos Afins. São Paulo: Editora Saraiva, 2011, p. 54.
} 
organização". Os autores acreditam que, apesar da importância desse estudo para a história do direito, no estudo do direito comercial não são de maior importância, visto que as condições sociais e econômicas da Antiguidade, e especialmente as romanas, não eram propícias à estruturação jurídica do comércio. $^{32}$

WALDEMAR FERREIRA, por sua vez, ilustra que "formou-se, certamente, em Roma, como em toda a parte, a figura que hoje se reputa da pessoa jurídica. Nada se depara de novo, quanto a isso, senão o seu reconhecimento e sua feitura doutrinária. Nisso reside, certamente, a novidade". 33

JOSÉ LAMARTINE CORRÊA DE OLIVEIRA, ao se referir ao surgimento das pessoas jurídicas, explica que é no direito privado que "surgem e se desenvolvem as grandes categorias típicas de instituições humanas sobre as quais se debruça o legislador para reconhecer-lhes ou não as características da pessoa jurídica - as associações, as fundações, as sociedades, de pessoas ou de capitais, civis ou mercantis." ${ }^{34}$

LAMY FILHO e BULHÕES DE PEDREIRA ensinam, ainda, que "os tipos mais antigos de sociedades mercantis formaram-se na Idade Média. Para tanto contribuíram as condições sociais e políticas da época especialmente a partir do século XI - que estimulavam as associações e o desenvolvimento do comércio e levaram à formação do direito comercial". ${ }^{35}$

Conforme explica FÉRES, na Idade Média os negócios societários se difundiam com liberdade e, apenas com o surgimento das codificações modernas, passou-se a elencar os tipos de sociedade:

\footnotetext{
${ }^{32}$ LAMY FILHO, Alfredo; PEDREIRA, José Luiz Bulhões. A Lei das S.A. Rio de Janeiro: Renovar, $3^{a}$ edição 1997, vol. I, p. 24.

${ }_{33}$ Waldemar Ferreira, Tratado de Sociedades Mercantis. Rio de Janeiro: Editora Nacional de Direito Ltda., 5aedição, vol. I, 1958, p.123.

${ }^{34}$ OLIVEIRA, José Lamartine Corrêa. A Dupla crise da Pessoa Jurídica. São Paulo: Saraiva, 1979, p. 29.

${ }^{35}$ LAMY FILHO, Alfredo; PEDREIRA, José Luiz Bulhões. A Lei das S.A. Rio de Janeiro:

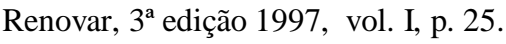


$\mathrm{Na}$ Idade Média, tempos áureos do desenvolvimento do comércio e do direito comercial, os negócios societários também se difundiam com ampla liberdade. A autonomia da vontade delineava amplamente os arranjos entre os comerciantes, sendo que o reiterado uso de certas formas acabou criando um rol de tipos de sociedades, então em caráter aberto.

A partir das Codificações modernas, em que se elencavam os tipos de sociedade relembre-se, verbi gratia, do Code de Commerce com seus três tipos societários , surge a questão da (a)tipicidade societária. ${ }^{36}$

Mais tarde, surgiriam as companhias colonizadoras que, nas palavras de LAMY FILHO E BULHÕES PEDREIRA "nasceram da associação dos Estados europeus com comerciantes e investidores em resposta a desafios econômicos e políticos criados pelos grandes descobrimentos". Os ilustres autores dispõem, ainda, que "os descobrimentos criaram a necessidade de organizações com escala muito superior à das unidades produtivas então conhecidas: as possibilidades de lucro que a exploração do Novo Mundo, e do caminho das Índias, oferecia à iniciativa dos governos e dos particulares, somente podiam ser aproveitadas com grande volume de capital, mobilizados onde quer que pudessem ser encontrados." ${ }^{37}$

Com novas necessidades surgindo, novas modalidades de tipos, em consequência, apareciam. Nesse sentido, ROBERT VON MAYR dispõe:

Posto que, provavelmente, todas as modalidades societárias tivessem origem comum, não tardaram em desenvolver-se, cada qual em seus próprios leitos, formas especiais de sociedades, provocadas pelas diferentes necessidades econômicas. ${ }^{38}$

Feita uma breve análise histórica, entende-se que a tipicidade em matéria societária pode ser definida como a vinculação dos agentes à escolha de um dos tipos de estrutura organizacional propostos, contendo cada tipo uma determinada função.

\footnotetext{
${ }^{36}$ FÉRES, Marcelo Andrade. Sociedade em Comum - Disciplina Jurídica e Institutos Afins. São Paulo: Editora Saraiva, 2011, pp. 56 e 57.

${ }^{37}$ LAMY FILHO, Alfredo; PEDREIRA, José Luiz Bulhões. A Lei das S.A. Rio de Janeiro: Renovar, $3^{\text {a }}$ edição 1997, vol. I, p. 32.

${ }^{38}$ Robert Von Mayr. Historia del Derecho Romano. Trad. Espanhola de Wesceslao Roces. Barcelona: Editorial Labor, S.A, 1926, vol. II, pág. 179. Apud Waldemar Ferreira. Tratado de Sociedades Mercantis. Rio de Janeiro: Editora Nacional de Direito Ltda., $5^{\text {a }}$ edição, vol. I, 1958, p. 199.
} 
FÉRES ensina que "uma sociedade típica em concreto revela-se pela confluência de suas característica legais e daquelas que as partes voluntariamente lhe dedicam. Os tipos societários servem como modelo em que há um equacionamento político e econômico". 39

Isso se dá porque, apesar de os tipos societários serem descritos em normas, há alguma (apenas no âmbito das normas dispositivas) flexibilidade às partes, dentro daquele modelo típico, de adequá-lo aos seus interesses.

Uma ressalva deve ser feita: não se tratará aqui de cada um dos tipos societários existentes e de suas funções, restringindo-se à análise dos aspectos concernentes aos tipos societários de forma generalizada. Desta forma, passemos ao estudo dos fundamentos da tipicidade.

\subsection{Fundamentos do princípio da tipicidade}

\section{Segundo explica PONTES DE MIRANDA:}

A tipicidade tem causas históricas, por muito fundada no direito romano, porém não só a vida jurídica, nos tempos posteriores e nos dias de hoje, atuou e atua, como também o trato dos negócios, em caracterizações inevitáveis.

O tráfico jurídico não só tipiciza ou corrige o tipo. Por vezes, suscita tipos novos (e.g., no direito brasileiro, a duplicata mercantil), ou negócios jurídicos atípicos. A vida muda. Embora os princípios permaneçam, mudam-se estruturas e conteúdos de negócios jurídicos. De ordinário, as regras jurídicas só são invocáveis quando faltam elementos explícitos de vontade ${ }^{40}$.

Além de uma razão histórica, a tipicidade é fundada em razões de outras naturezas, sobretudo do ponto de vista econômico e jurídico.

\footnotetext{
${ }^{39}$ FÉRES, Marcelo Andrade. Sociedade em Comum - Disciplina Jurídica e Institutos Afins. São Paulo: Editora Saraiva, 2011, pp. 59 e 60.

${ }^{40}$ MIRANDA, Pontes de. Tratado de Direito Privado. Parte Geral. São Paulo: Editora Revista dos Tribunais, $3^{\text {a }}$ edição, 1984, Tomo XXXVIII, p. 366.
} 


\subsubsection{Enfoque econômico e organizacional}

Inicialmente, é importante mencionar que, para se justificar que a adoção de um sistema da tipicidade é a melhor opção, antes é necessário entender qual é a vantagem de se organizar em sociedade.

SYLVIO MARCONDES trata da importância de uma concepção econômica da empresa:

Há, indubitavelmente, na concepção de empresa comercial, um substrato econômico, consistente na organização dos fatores de produção, realizada pelo empresário, no sentido da atividade empreendedora, visando à obtenção de lucro e correndo o risco correspondente. Esse substrato, por estar implícito em todos os enunciados propostos para a definição de empresa, pode ser havido como ponto pacífico na controvérsia, a qual somente surge, quando se trata de complementar o conceito econômico, mediante elementos de ordem jurídica. ${ }^{41}$

BRUNO ROBERT, ao tratar da formação do contrato de sociedade e sua função instrumental, ensina que:

A própria escolha da estrutura da sociedade também é determinada por razões econômicas. Os indivíduos que escolhem se organizar em sociedade o fazem porque acreditam que atingirão seus objetivos mais facilmente se trabalharem em conjunto e que seus esforços serão mais eficientemente aproveitados se adotarem uma forma preestabelecida e coletivamente respeitada de relacionamento entre si e com terceiros. ${ }^{42}$

Dentro desse raciocínio, em uma abordagem mais econômica, em sua obra "The Nature of the Firm" ", RONALD COASE explica que a concepção clássica da economia entende que o mercado funciona de forma independente, coordenado pelo que ele denomina price mechanism ou, em tradução livre, mecanismo de formação de preços, responsável por coordenar a alocação de fatores de produção. No entanto, o economista questiona que, se o mercado fosse guiado por esse mecanismo, qual seria a importância das empresas (firms) no mercado?

\footnotetext{
${ }^{41}$ MARCONDES, Sylvio. Problemas de Direito Mercantil. São Paulo: Max Limonad, 1970, p. 39.

42 ROBERT, Bruno. Dividendo Mínimo Obrigatório nas Sociedades por Ações Brasileiras. Apuração, Declaração e Pagamento. São Paulo: Quartier Latin, 2011, p. 21.

${ }^{43}$ COASE, Ronald Harry. The Nature of the Firm. Economica, vol. 4, n ${ }^{\circ} 16,1937$, publicação de Blackwell Publishing (The London School of Economics and Political Science).
} 
Assim, ele destaca que, com a organização em uma empresa (firm), as transações de mercado são eliminadas e, no lugar de uma estrutura complicada surge a figura do empreendedor-coordenador (entrepreneurcoordinator), que assumirá a direção da produção, suprimindo-se, assim, o mecanismo de formação de preços:

\begin{abstract}
"Why is such organization necessary? Why are there these "islands of conscious power"? Outside the firm, price movements direct production, which is coordinated through a series of exchange transactions on the market. Within a firm these market transactions are eliminated, and in place of the complicated market structure with exchange transactions is substituted the entrepreneur-coordinator, who directs production. (...) It can, I think, be assumed that the distinguishing mark of the firm is the supersession of the price mechanism". ${ }^{44}$
\end{abstract}

Em consequência, os custos provenientes do mecanismo de formação de preços são suprimidos. Nessa acepção, COASE afirma: "the main reason why it is profitable to establish a firm would seem to be that there is a cost of using the price mechanism." 45

Seguindo a mesma ideia, o economista argumenta que a organização em empresa (firm) faz com que os custos de transação sejam menores do que nas transações realizadas de forma descentralizada por meio da celebração de contratos no mercado:

(...) although production could be carried out in a completely decentralized way by means of contracts between individuals, the fact that it costs something to enter into these transactions means that firms will emerge to organize what would otherwise be market transactions whenever their costs were less than the costs of carrying out the transactions through the market ${ }^{46}$.

Referindo-se a COASE, OLIVER HART explica que, com a existência de uma empresa, as transações ocorrem como resultado de instruções ou ordens emitidas por um superior, e o mecanismo de formação de preços é suprimido. Segundo o autor, a teoria de COASE de que as

\footnotetext{
${ }^{44}$ COASE, Ronald Harry. The Nature of the Firm. Economica, vol. 4, no 16, 1937, publicação de Blackwell Publishing (The London School of Economics and Political Science) pp. 388 e 389.

${ }^{45}$ COASE, Ronald Harry. The Nature of the Firm. Economica, vol. 4, nº 16, 1937, publicação de Blackwell Publishing (The London School of Economics and Political Science) p. 390.

${ }^{46}$ The firm, the Market, and the Law. Chicago: The University of Chicago Press, 1988, p. 7.
} 
empresas ajudam na economia de custos de transação foi amplamente aceita. $^{47}$

EASTERBROOK e FISCHEL também tratam da questão dos custos de transação, em sua obra "The Economic Structure of Corporate Law":

It is important to distinguish between isolated transactions and governance structures. There are high costs of operating capital and managerial markets, just as there are high costs of other methods of dealing with the divergence of interests. It is inevitable that a substantial amount of undesirable slack of selfdealing will occur. The question is whether these costs can be cut by mechanisms that are not themselves more costly. ${ }^{48}$

Não só autores estrangeiros abordam essa questão. RACHEL SZTAJN traz uma excelente explicação sobre a questão dos riscos inerentes às operações no mercado, dos custos de transação envolvidos e da consequente opção pela empresa e pela organização:

Diferentes técnicas são empregadas pelos agentes econômicos para exercer domínio sobre a informação e o conhecimento disseminados em ambiente social que muda rapidamente. Por isso, para superar essas dificuldades, reduzir riscos e custos inerentes à produção de bens e serviços destinados a mercados, os agentes optam por criar uma outra estrutura, destinada a facilitar o tráfico negocial, organização essa que é a empresa, estrutura hierárquica em que se procura harmonizar esses diversos interesses, ao mesmo tempo em que se diminuem custos de transação.

Costuma-se dizer que a decisão de produzir para mercados depende da opção do empreendedor em correr o risco dos mercados ou, de forma elíptica, fazer a escolha entre empresa e mercado. Assim, operações que ocorreriam em mercados são realizadas dentro das organizações, o que aumenta a importância dos mecanismos de coordenação. ${ }^{49}$

Outro ponto que também é destacado por COASE se refere ao fato de que transações no mercado e transações organizadas por meio de uma empresa (firm) são normalmente tratadas de forma diversa pelo Estado e

\footnotetext{
${ }^{47}$ HART, Oliver. An Economist Perspective on the Theory of the Firm. Columbia Law Review, vol. 89, 1989, pp. 1760-1762.

${ }^{48}$ EASTERBROOK, Frank; e FISCHEL, Daniel. The Economic Structure of Corporate Law. London: Harvard University Press, 1948, p.7.

${ }^{49}$ SZTAJN, Rachel. Teoria Jurídica da Empresa: Atividade Empresária e Mercados. São Paulo: Atlas, 2004, pp. 72 e 73.
} 
outros agentes reguladores. É o que acontece, por exemplo, com o tratamento tributário. ${ }^{50}$

Além desses fatores, com a organização em sociedade, os agentes também passam a dispor de diversos mecanismos que auxiliam na proteção do patrimônio pessoal e na limitação da responsabilidade, o que permite que maiores riscos sejam assumidos e, consequentemente, maiores podem vir a ser os ganhos provenientes da atividade.

Como vantagens e benefícios de se conduzir um negócio em forma de sociedade (mais especificamente em uma companhia), HENRY BALLANTINE sugere:

Corporate advantages or benefits. - There are certain advantages obtainable by doing business or investing capital in a business unit conducted in corporate form. The principal ones are: (1) the capacity to act as a legal unit, to hold property, to contract, to sue and be sued as a distinct entity; (2) limitation of or exemption from individual liability of shareholders; (3) continuity of existence; (4) transferability of shares; (5) centralized management by board of directors; (6) standardized methods of organization, management and finance prescribed by corporation acts for the protection of shareholders and creditors, including a more or less standardized system of shareholders' relations, rights, and remedies. ${ }^{51}$

Diversos são os elementos trazidos por BALLANTINE, mas talvez os mais importantes estejam consubstanciados nos conceitos de separação patrimonial e de limitação de responsabilidade.

Sobre a questão da separação patrimonial, destaca-se o caso inglês Salomon v. Salomon \& Co. ${ }^{52}$, que se tornou um precedente e paradigma no tema e que deu origem à teoria da disregard doctrine. De forma resumida, o caso envolvia um comerciante de sapatos (Salomon), que possuía uma fábrica com seu nome. O fabricante decidiu, então, constituir junto com seus seis filhos e sua esposa, uma sociedade, a Aaron Salomon \& Co. Ltd. ${ }^{53}$

\footnotetext{
${ }^{50}$ COASE, Ronald Harry. The Nature of the Firm. Economica, vol. 4, no 16, 1937, publicação de Blackwell Publishing (The London School of Economics and Political Science) p. 393.

51 BALLANTINE, Henry Winthrop. Ballantine on Corporations. Chicago: Callaghan and Company, 1946, p.3.

${ }^{52}$ Salomon v. A. Salomon \& Co. Ltd. (1897), AC 22.

${ }^{53} \mathrm{Na}$ época, havia uma determinação na lei inglesa de que para a constituição de uma sociedade, eram necessários, no mínimo, 7 membros.
} 
Salomon tinha em seu nome a maioria das ações da companhia, tendo o resto dos familiares uma ação cada um.

Em pouco tempo, a companhia entrou em liquidação e diversos credores insatisfeitos tentaram obter o pagamento de seus créditos alegando que o patrimônio pessoal de Salomon deveria ser atingindo, uma vez que a companhia era apenas um instrumento utilizado por ele para criar uma barreira em relação a seu patrimônio pessoal. Os credores afirmavam que os familiares de Salomon eram apenas sócios fictícios.

Em que pese o juízo de primeiro grau ter responsabilizado pessoalmente o comerciante pelos débitos da companhia, a decisão foi reformada pela Câmara dos Lordes, que prestigiou a separação patrimonial entre a sociedade e a figura do sócio.

Veja-se o que fala PAUL DAVIES sobre o caso:

The Salomon case established that (a) provided the formalities of the Act are complied with, a company will be validly incorporated, even if it is only a "one person" company and (b) the courts will be reluctant to treat a shareholder as personally liable for the debts of the company by "piercing the corporate veil". ${ }^{54}$

Da mesma forma, ARMOUR, HANSMANN e KRAAKMAN:

The first and most important contribution of corporate law, as of other forms of organizational law, is to permit a firm to serve this role by permitting the firm to serve as single contracting party that is distinct from the various individuals who own or manage the firm. In so doing, it enhances the ability of these individuals to engage together in joint projects.

The core element of the firm as a nexus for contracts is what the civil law refers to as 'separate patrimony'.

(...) The core function of this separate patrimony has been termed 'entity shielding', to emphasize that it involves shielding the assets of the entity - the corporation - from the creditors of the entity's owner. ${ }^{55}$

Visto isso, faz-se alusão à outra vantagem que a organização em empresa pode trazer: a especialização do trabalho que, na maioria das

\footnotetext{
${ }^{54}$ DAVIES, Paul L. Gower and Davies' Principles of Modern Company law. England: Thomson Reuters Limited, 2008, p. 35 e 36.

${ }^{55}$ ARMOUR, John; HANSMANN, Henry; e KRAAKMAN, Reinier. What is Corporate Law? In: The Anatomy of Corporate Law - A Comparative and Functional Approach. New York: Oxford University Press Inc., 2009, p. 6.
} 
vezes, tende a fazer com que a produtividade aumente. É o que explicam

\section{EASTERBROOK e FISCHEL:}

The firm - an aggregation of people banded together for a longer period - permits greater use of specialization. People can organize as teams with the functions of each member identified, so that each member's specialization makes the team as a whole more productive that it would otherwise be. ${ }^{56}$

Ainda, outro aspecto importante está consubstanciado no fato de que as sociedades sobrevivem à pessoa do sócio e, portanto, sobrevivem no tempo, ao contrário do que ocorre nas relações assumidas individualmente.

Todos esses fatores, em conjunto, acabam permitindo que os agentes assumam maiores riscos, que não seriam tomados fora do âmbito de uma estrutura organizacional capaz de promover essa proteção. As transações no mercado são mais arriscadas e propensas a atingir diretamente o patrimônio do indivíduo, o que desestimula maiores investimentos e, consequentemente, diminui a possibilidade de se obter maiores resultados.

Finalmente, vale trazer a opinião de HANSMANN e KRAAKMAN sobre o objetivo do direito de empresa. Os autores alegam que sua função é atender aos interesses da sociedade como um todo e, mais adiante, explicam porque a empresa tem interesse em fazer com que as transações comerciais sejam benéficas não só para os acionistas, como também para todas as partes envolvidas:

What is the goal of corporate law, as distinct from its immediate functions of defining a form of enterprise and containing the conflicts among the participants in this enterprise? As a normative matter, the overall objective of corporate law as of any branch of law - is presumably to serve the interests of society as a whole. More particularly, the appropriate goal of corporate law is to advance the aggregate welfare of all who are affected by a firm's activities, including the firm's shareholders, employees, suppliers, and customers, as well as third parties such as local communities and beneficiaries of the natural environment. This is what economists would characterize as the pursuit of overall social efficiency.

\section{$(\ldots)$}

Second, such claims can be understood as saying, more modestly, that focusing principally on the maximization of shareholder returns is, in general, the best means by which corporate law can serve the broader goal of advancing overall

\footnotetext{
56 EASTERBROOK, Frank; e FISCHEL, Daniel. The Economic Structure of Corporate Law. London: Harvard University Press, 1948, p.7.
} 
social welfare. In general, creditors, workers, and customers will consent to deal with a corporation only if they expect themselves to be better off as a result. Consequently, the corporation - and, in particular, its shareholders, as the firm's residual claimants and risk bearers - have a direct pecuniary interest in making sure that corporate transactions are beneficial, not just to the shareholders, but to all parties who deal with the firm. We believe that this second view is - and surely ought to be - the appropriate interpretation of statements by legal scholars and economists asserting the shareholder value is the proper object of corporate law. ${ }^{57}$

Feitas essas observações sobre a importância da organização em sociedade, sobretudo sob o ponto de vista econômico, passa-se à análise dos argumentos jurídicos que embasam a adoção de um sistema fechado e previsível.

\subsubsection{Enfoque jurídico}

Sob o ponto de vista jurídico, diversos são os argumentos utilizados por aqueles que sustentam a aplicação do princípio da tipicidade nas relações societárias, mas os principais se referem à tutela do interesse de terceiros que se relacionam com as sociedades e ao equilíbrio e à estabilidade das relações no âmbito interno das sociedades.

A definição de tipos em matéria societária busca assegurar a organização e o controle sobre a alocação de recursos no mercado e proteger os terceiros que contratam com a sociedade, pois lhes é dada a oportunidade de conhecer, desde logo, o regime de responsabilidade dos sócios $^{58}$.

\section{Como explica FÉRES:}

Os tipos societários servem como modelo em que há um equacionamento político e econômico. As disposições legais de um tipo conformam-se em equilíbrio, sopesando interesses internos e externos da sociedade. Servem como modelo estrutural da sociedade, corporificando-a com órgãos, dizendo de sua representação e da formação da vontade do seio social.

\footnotetext{
${ }^{57}$ ARMOUR, John; HANSMANN, Henry; e KRAAKMAN, Reinier. What is Corporate Law? In: The Anatomy of Corporate Law - A Comparative and Functional Approach. New York: Oxford University Press Inc., 2009, pp. 28 e 29.

58 PELA, Juliana Krueger. As Golden Shares no Direito Brasileiro. São Paulo: Quartier Latin, 2012, p. 109.
} 
Da mesma forma, RACHEL SZTAJN comenta que "para a descrição dos tipos de sociedades recorre-se à análise das relações internas e externas. Com base nessa dupla caracterização é que é possível deduzir as cláusulas atípicas e distinguir as sociedades atípicas das formas típicas."

Como expõe o clássico autor CARVALHO DE MENDONÇA "qualquer que seja a forma legal da sociedade comercial, a sua existência pressupõe um contrato, que se não limita a criar obrigações entre os que nele intervêm”. O autor explica, ainda, que do contrato nasce a sociedade, que agirá em nome próprio e que se torna sujeito ativo e passivo de obrigações próprias, sendo a verdadeira titular dos direitos e obrigações provenientes do exercício da sua atividade. ${ }^{60}$

Mais adiante, CARVALHO DE MENDONÇA explica que não só a personalidade jurídica das sociedades comerciais manifesta-se nas suas relações com terceiros, mas também em relações com os próprios sócios. ${ }^{61}$

Mencionados os dois principais fundamentos jurídicos da adoção da tipicidade taxativa no que se refere ao direito societário, mostra-se interessante analisá-los de forma mais minuciosa.

\subsubsection{Tutela do interesse de terceiros}

GANDARA explica ${ }^{62}$ que é generalizado o princípio de que particulares não podem inventar novas formas de sociedade, podendo apenas eleger um dos tipos previstos em lei por razões de caráter políticojurídico, ou seja, que no direito das sociedades, entram em jogo interesses

\footnotetext{
${ }^{59}$ SZTAJN, Rachel. Contrato de Sociedade e Formas Societárias. São Paulo: Saraiva, 1989, pp. 161 e 162.

${ }^{60}$ MENDONÇA, José Xavier Carvalho de. Tratado de Direito Comercial Brasileiro. Rio de Janeiro: Livraria Freitas Bastos, $6^{\text {a }}$ edição (revista por Roberto Carvalho de Mendonça), 1963, vol. III, pp. 84 e 85.

${ }^{61}$ MENDONÇA, José Xavier Carvalho de. Tratado de Direito Comercial Brasileiro. Rio de Janeiro: Livraria Freitas Bastos, $6^{\text {a }}$ edição (revista por Roberto Carvalho de Mendonça), 1963, vol. III, p. 85.

${ }^{62}$ Sobre esse aspecto, deve-se levar em consideração que o autor, ao tratar da questão, tem como plano de fundo o cenário espanhol da década de 70 .
} 
de terceiros e, ao adotar-se um dos esquemas previstos em lei, proporcionase segurança e transparência:

Esta toma de posición ante el problema obedece sobre todo a consideraciones de carácter político-jurídico: la idea central es que en Derecho de sociedades, lo mismo que en Derecho de cosas, entran en juego intereses que exceden de la esfera jurídico-personal de los propios intervinientes. Cuando un negocio jurídico despliega su eficacia frente a terceros, sólo pueden adoptarse los esquemas expresamente previstos por la ley, ya que en ello radica justamente la técnica legal de protección de los intereses de aquéllos y, al mismo tempo, la garantía de seguridad y transparencia del tráfico. ${ }^{63}$

Em complemento, o autor espanhol afirma que "en la doctrina es pacífica la opinión de que la existencia de este sistema obedece básicamente a la necesidad de proteger los intereses de los terceros”. Segundo ele, se trataria da aplicação da regra genérica de proteção da confiança e, deste modo, um instrumento destinado a garantir a segurança das relações jurídicas. $^{64}$

Para JULIANA KRUEGER PELA, a vedação da criação de estruturas societárias atípicas embora sofra críticas, não é desprovida de fundamento:

Com efeito, as sociedades constituem, sob o ponto de vista econômico, verdadeiros veículos para a mais eficiente alocação de bens no mercado e, como tais, postam-se como vértice de reiteradas e diversas relações jurídicas com outros agentes de mercado que não conhecem e não têm o ônus de conhecer eventuais arranjos atípicos que os sócios tenham decidido inserir no contrato ou estatuto social." ${ }^{.65}$

Apesar de sua importância, na opinião de GANDARA, o argumento de proteção do interesse de terceiros não é suficiente para justificar a adoção do sistema da tipicidade:

(...) no es seguro que la genérica remisión al interés de los terceros en la forma aquí descrita baste por sí sola para implantar un sistema que en algunos ordenamientos como el nuestro implica la derogación sig et simpliciter de una expresa declaración legal de libertad de invención y en otros - como el suizo o el

\footnotetext{
${ }^{63}$ GANDARA, Luis Fernandez de la. La Atipicidad en Derecho de Sociedades. Zaragoza: Pórtico, [s.d.], pp. 84 e 85.

${ }^{64}$ GANDARA, Luis Fernandez de la. La Atipicidad en Derecho de Sociedades. Zaragoza: Pórtico, [s.d.], p. 86.

${ }^{65}$ PELA, Juliana Krueger. As Golden Shares no Direito Brasileiro. São Paulo: Quartier Latin, 2012, p. 109.
} 
alemán - no tendrá más fundamento que el derivado de una interpretación modificativa de los textos legales. ${ }^{66}$

Para o autor, a proteção de terceiros não justifica por si só a existência da tipicidade. Primeiro porque não faz parte dos princípios que regem em caráter geral a conformação estrutural dos contratos. O interesse dos terceiros na tipicidade das relações jurídicas tem um fundamento basicamente econômico $^{67}$. Em segundo lugar e, sobretudo, porque o exame superficial da disciplina legal é suficiente para se notar a presença de outros elementos - como a vinculação das estruturas associativas a fins e funções específicos, ou as especialidades ligadas ao reconhecimento de personalidade jurídica e a organização das sociedades sob um sistema de mão comum - que estão orientados para um sistema de numerus clausus $^{68}$.

Ademais, lhe parece que a implantação do numerus clausus não resolve satisfatoriamente em um plano de lege lata o problema da proteção dos terceiros, por não se encontrar suficientemente fechado para cobrir as existências de tutela que a posição jurídica do terceiro reclama.

Conforme explica RACHEL SZTAJN, "se é possível existir sociedades que apresentem apenas relações internas, o mesmo não se dá com as relações externas que inexistem isoladas daquelas". Daí a importância de se considerar os dois polos do tema.

Apesar do senso comum de que a proteção dos interesses de terceiros consiste em um aspecto fundamental para a explicação do sistema da tipicidade, a boa doutrina destaca que essa não é sua única função. Como se viu, essa proteção não é absoluta e restam claras outras funções decorrentes da adoção do sistema taxativo de tipos.

\footnotetext{
${ }^{66}$ GANDARA, Luis Fernandez de la. La Atipicidad en Derecho de Sociedades. Zaragoza: Pórtico, [s.d.], p. 87.

${ }^{67}$ Neste ponto, faz-se referência ao item que trata do enfoque econômico da organização.

${ }^{68}$ GANDARA, Luis Fernandez de la. La Atipicidad en Derecho de Sociedades. Zaragoza: Pórtico, [s.d.], pp. 87 e 88.
} 


\subsubsection{Estabilidade e equilíbrio das relações internas}

Tendo sido abordada a razão externa daqueles que sustentam a aplicação do princípio da tipicidade - a proteção dos interesses de terceiros -, necessário se faz abordar a sua razão no âmbito interno da sociedade, ou seja, a estabilidade das relações internas entre os sócios.

Tamanha a importância deste aspecto, WIEDEMANN o classifica como sendo um dos três elementos presentes em qualquer norma societária. Em outras palavras, o jurista alemão, acerca do conteúdo das necessárias normas societárias ${ }^{69}$ destaca três áreas para as quais o legislador e os próprios membros devem atentar ${ }^{70}$. Uma delas é justamente o status socii (Mitgliederstatus), que diz respeito à disciplina dos direitos e deveres dos sócios perante a organização societária e perante os outros sócios. ${ }^{71}$

Da mesma forma, ao tratar da tutela do equilíbrio das relações internas entre sócios como uma justificativa para a adoção do numerus clausus, RACHEL SZTAJN entende que esta se prende à posição do indivíduo em relação aos demais membros do grupo, mas não basta para que se chegue à tipicidade fechada das estruturas societárias ${ }^{72}$.

Ao versar sobre o status socii, DANIELA RAMOS MARQUES MARINO destaca que "a aplicação do conceito é de grande relevância, especialmente nas hipóteses em que ocorrem modificações do status socii, as quais acabam por repercutir ainda que potencialmente na esfera de direitos e obrigações do sócio e na sua relação com a sociedade (...)."73

\footnotetext{
69 Para o exame, o jurista abstrai as normas relacionadas à constituição e à dissolução das sociedades.

${ }^{70}$ Além do status socii, objeto de análise neste trabalho, o jurista faz referência à determinação da finalidade e à organização.

${ }^{71}$ WIEDEMANN, Herbert. Gesellschaftsrecht I - Grundlagen (Exceto do Direito Societário I Fundamentos). Munique: Editora Beck, 1980. Tradução de Erasmo Valladão A. e N. França. In: FRANÇA, Erasmo Valladão Azevedo e Novaes, Direito Societário Contemporâneo I. São Paulo: Quartier Latin do Brasil, 2009, pp. 13 e 14.

${ }^{72}$ SZTAJN, Rachel. Contrato de Sociedade e Formas Societárias. São Paulo: Saraiva, 1989, p. 55.

${ }^{73}$ MARINO, Daniela Ramos Marques. O Status Socii. In: FRANÇA, Erasmo Valladão Azevedo e Novaes, Direito Societário Contemporâneo I. São Paulo: Quartier Latin do Brasil, 2009, p. 182.
} 
Segundo versa RACHEL SZTAJN, "nas relações internas estão calcados os interesses individuais dos sócios, sua participação nos lucros e na administração."74

Uma abordagem interessante na obra de RACHEL SZTAJN se refere à possibilidade de existirem sociedades que apresentam apenas relações internas, não se manifestando externamente ${ }^{75}$. A professora utiliza como exemplos (i) as sociedades em conta de participação, nas quais apenas o sócio ostensivo obriga-se perante terceiro, enquanto o sócio oculto (ou participante) obriga-se tão somente em relação ao sócio ostensivo, nos termos do contrato social; (ii) os casos em que um sócio de um tipo qualquer de sociedade associa outra pessoa à sua parte, sem que esse terceiro se torne sócio da sociedade; (iii) os consórcios sem atividade externa; e (iv) os grupos de fato. ${ }^{76}$

WIEDEMANN classifica os direitos e deveres dos sócios em direitos de participação (voto, poderes de gestão social), direitos patrimoniais (participação nos lucros, direitos de fruição), direitos de informação e fiscalização e direito de se retirar da organização societária ${ }^{77}$. Entre os deveres, enumera o dever de contribuir, o dever de colaborar para a gestão social e o dever de lealdade ${ }^{78}$.

Na legislação societária brasileira atual, um ótimo exemplo de norma que trata da relevância das relações internas da sociedade é constatado no artigo 109 da Lei das S.A., que dispõe:

\footnotetext{
${ }^{74}$ SZTAJN, Rachel. Contrato de Sociedade e Formas Societárias. São Paulo: Saraiva, 1989, p. 162.

${ }^{75}$ No entanto, o mesmo não se dá, conforme já falado, com as relações externas, que inexistem isoladas das externas.

${ }^{76}$ SZTAJN, Rachel. Contrato de Sociedade e Formas Societárias. São Paulo: Saraiva, 1989, p. 162.

77 Carvalho de Mendonça, por exemplo, divide os direitos em patrimoniais e pessoais. MENDONÇA, José Xavier Carvalho de. Tratado de Direito Comercial Brasileiro. Rio de Janeiro: Livraria Freitas Bastos, $6^{\text {a }}$ edição (revista por Roberto Carvalho de Mendonça), 1963, vol. III, pp. 71 e 72.

${ }^{78}$ WIEDEMANN, Herbert, Gesellschaftsrecht I - Grundlagen (Exceto do Direito Societário I Fundamentos). Munique: Editora Beck, 1980. Tradução de Erasmo Valladão A. e N. França. In: FRANÇA, Erasmo Valladão Azevedo e Novaes, Direito Societário Contemporâneo I. São Paulo: Quartier Latin do Brasil, 2009, p. 14.
} 
Art. 109. Nem o estatuto social nem a assembleia-geral poderão privar o acionista dos direitos de:

I - participar dos lucros sociais;

II - participar do acervo da companhia, em caso de liquidação;

III - fiscalizar, na forma prevista nesta Lei, a gestão dos negócios sociais;

IV - preferência para a subscrição de ações, partes beneficiárias conversíveis em ações, debêntures conversíveis em ações e bônus de subscrição, observado o disposto nos artigos 171 e 172;

V - retirar-se da sociedade nos casos previstos nesta Lei.

$\S 1^{\circ}$ As ações de cada classe conferirão iguais direitos aos seus titulares.

$\S 2^{\circ}$ Os meios, processos ou ações que a lei confere ao acionista para assegurar os seus direitos não podem ser elididos pelo estatuto ou pela assembléia-geral.

$\S 3^{\circ} \mathrm{O}$ estatuto da sociedade pode estabelecer que as divergências entre os acionistas e a companhia, ou entre os acionistas controladores e os acionistas minoritários, poderão ser solucionadas mediante arbitragem, nos termos em que especificar.

Tal dispositivo enumera os direitos essenciais do acionista, direitos esses que não podem ser elididos pelo estatuto social, tampouco pela assembleia geral.

Nesse contexto, se alguém celebra um contrato de sociedade anônima já sabe, de antemão, que o exercício dos direitos previstos no artigo 109 será a ele garantido e que, em sua atuação no âmbito societário, deverá sempre observar os referidos direitos na relação com os outros acionistas e com a sociedade.

Assim, esses direitos são vinculados ao tipo societário eleito, que nesse caso é a sociedade anônima, tendo a função de estabelecer um mínimo de organização interna societária sobre a qual não se pode dispor de forma diversa.

Diversos são os exemplos de disposições que tratam do âmbito interno e da estabilidade das relações internas das sociedades. No entanto, apesar da importância desse elemento na análise dos tipos societários, necessário se faz conjugá-lo com as relações externas, estabelecidas com terceiros.

Apesar de esses dois argumentos serem considerados os mais importantes para a justificação de um sistema taxativo de tipos e serem os mais mencionados entre os autores que tratam do tema, não se pode descartar outros fatores que contribuem para fundamentar a sua adoção. 


\subsubsection{Outros fundamentos}

RACHEL SZTAJN faz referência, ainda, ao caráter de instituição que algumas sociedades assumem e ao fato de que as sociedades são sujeitos de direito.

Quanto ao segundo ponto, a autora menciona que há quem entenda que, como só a lei pode criar ou reconhecer as pessoas como sujeitos de direito, não seria factível admitir que os particulares pudessem criar esses sujeitos.

Quanto a esse último argumento, a autora entende que pode ser afastado, visto que a personificação acresce à sociedade já constituída por força do registro. ${ }^{79}$

\footnotetext{
${ }^{79}$ SZTAJN, Rachel. Contrato de Sociedade e Formas Societárias. São Paulo: Saraiva, 1989, p. 55.
} 


\section{Principio da autonomia da vontade}

O presente capítulo tem como objetivo analisar as características do princípio da autonomia da vontade e a sua importância, relacionando-o com o princípio destacado no capítulo anterior. Para tanto, é preciso recorrer ao seu conceito, sua disciplina no direito brasileiro e à discussão da compatibilização deste princípio com o princípio da tipicidade.

\subsection{Conceito}

Autonomia significa poder se autogovernar e ter a faculdade de traçar suas próprias normas de conduta, sem imposições de ordem estranha, é o direito de tomar decisões livremente, com liberdade, independência moral ou intelectual. Possui significado contrário ao de heteronomia, que significa a sujeição a uma lei exterior ou à vontade de outrem ${ }^{80}$.

O princípio da autonomia da vontade, também denominado por alguns autores de princípio da autonomia privada ${ }^{81}$, do autorregramento da vontade ou da liberdade de contratar, é o poder negocial conferido pelo ordenamento jurídico aos particulares para autorregulamentação de seus interesses, nos limites estabelecidos ${ }^{82}$.

\footnotetext{
${ }^{80}$ CABRAL, Érico de Pina. A “Autonomia” no Direito Privado. Revista de Direito Privado, vol. 19, jul/2004, p. 83 e ss. Acesso pela Revista dos Tribunais Online em 19.09.2012.

${ }^{81}$ Francisco dos Santos Amaral Neto entende que apesar de ser considerado como sinônimo do princípio da autonomia da vontade por grande parte da doutrina contemporânea, o princípio da autonomia privada com ele não se confunde, "existindo entre ambos sensível diferença que se realça com o enfoque do fenômeno em apreço na perspectiva da nomogênese jurídica”. Segundo o autor, pode-se dizer que a expressão autonomia da vontade tem conotação mais subjetiva, psicológica, enquanto a autonomia privada marca o poder da vontade de um modo objetivo, concreto e real. AMARAL NETO, Francisco dos Santos. A Autonomia Privada como Princípio Fundamental da Ordem Jurídica - Perspectivas Estrutural e Funcional. In: Doutrinas Essenciais de Direito Civil, vol. 2, out/2010, p. 579 e ss. Acesso pela Revista dos Tribunais Online em 19.09.2012.

82 LÔBO, Paulo Luiz Netto. Autonomia da Vontade (no Direito Contratual). In: TORRES, Ricardo Lobo; KATAOKA, Eduardo Takemi; GALDINO, Flavio, organizadores; TORRES, Silvia Faber Torres, supervisora. Dicionário de Princípios Jurídicos. Rio de Janeiro: Elsevier, 2011, p. 127.
} 
Segundo EMILIO BETTI, “a autonomia privada consiste, em linhas gerais, no poder assegurado aos particulares de autorregulamentação de seus interesses e relações" ${ }^{\prime 3}$.

Nas palavras de PONTES DE MIRANDA:

Já aqui se pode caracterizar o que se passa, em verdade, com os atos humanos interiores ao campo de atividade, a que se chama auto-regramento da vontade, "autonomia privada", ou "autonomia da vontade": é o espaço deixado às vontades, sem se repelirem do jurídico tais vontades. Enquanto, a respeito de outras matérias, o espaço deixado à vontade fica por fora do direito, sem relevância para o direito; aqui, o espaço que se deixa à vontade é relevante para o direito $^{84}$.

Para o autor, o autorregramento da vontade é que permite que a pessoa, conhecendo o que se produzirá com seu ato, negocie ou não, tenha ou não o gestum que a vincule ${ }^{85}$.

JULIANA KRUEGER PELA propõe uma abordagem do valor e da extensão da autonomia privada em um contexto de utilização da técnica jurídica para o atendimento de funções econômicas e sociais. Segundo a autora, as teorias sobre autonomia no direito privado estão profundamente vinculadas ao debate acerca do negócio jurídico, tratando-se de teorias que atribuem aos indivíduos vontade jurídica eficaz, que caberá ao ordenamento estatal reconhecer. A seu ver, há uma perspectiva mais recente de necessária desvinculação da autonomia privada do negócio jurídico individual, e maior atenção à realidade e disciplina das relações de $\operatorname{mercado}^{86}$.

\footnotetext{
${ }^{83}$ BETTI, Emilio. Teoria Geral do Negócio Jurídico. Tradução de Fernando de Miranda. Coimbra: Coimbra Editora, 1969. Tradução de: Teoria General del Negozio Giuridico. $2^{\mathrm{a}}$ ed, 1950, v.1, p. 101. Apud PELA, Juliana Krueger. As Golden Shares no Direito Brasileiro. São Paulo: Quartier Latin, 2012, p. 97.

${ }^{84}$ MIRANDA, Pontes de. Tratado de Direito Privado. Parte Geral. Rio de Janeiro: Editor Borsoi, $3^{\text {a }}$ edição, 1970, Tomo III, pp. 54 e 55.

${ }^{85}$ MIRANDA, Pontes de. Tratado de Direito Privado. Parte Geral. São Paulo: Editora Revista dos

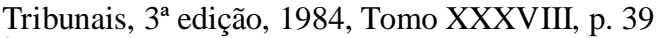

${ }^{86}$ PELA, Juliana Krueger. As Golden Shares no Direito Brasileiro. São Paulo: Quartier Latin, 2012, p. 102-105.
} 


\subsection{Autonomia da vontade no Código Civil de 2002}

O Código Civil de 2002 não faz referência explícita ao princípio da autonomia privada. Por sua vez, estabelece, no artigo 421, que "a liberdade de contratar será exercida em razão e nos limites da função social do contrato".

É importante mencionar que a aplicação da "função social do

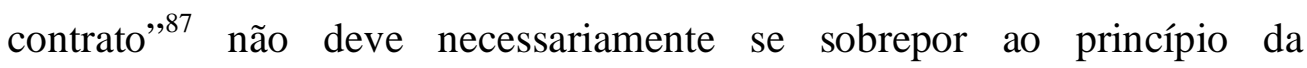
autonomia da vontade. Nesse sentido, o voto da ministra relatora NANCY ANDRIGHI, proferido no âmbito do Recurso Especial nº 972.436:

Embora o princípio da função social exerça uma tensão dialética sobre o princípio da autonomia da vontade, daí não se podem extrair regras universalmente aplicáveis a todos os litígios similares que se apresentam ao Poder Judiciário. Ao contrário, o exame da função social do contrato é um convite ao Poder Judiciário, para que ele construa soluções justas, rente à realidade da vida, prestigiando prestações jurisdicionais intermediárias, razoáveis, harmonizadoras e que, sendo encontradas caso a caso, não cheguem a aniquilar nenhum dos outros valores que orientam o ordenamento jurídico, como a autonomia da vontade (grifos meus) ${ }^{88}$.

Vale mencionar também que no plano constitucional, ${ }^{89}$ nossa ordem econômica e social baseia-se no princípio da livre iniciativa, prestigiando-se a autonomia da vontade ${ }^{90}$. No entanto, tem-se por fim "assegurar a todos existência digna, conforme os ditames da justiça social”, o que leva a

\footnotetext{
${ }^{87}$ Para Gustavo Tepedino, Heloisa Barboza e Maria Celina Bodin (citando Antônio Junqueira de Azevedo), até pouco tempo prevalecia a ideia de que eventuais restrições à liberdade de contratar não eram mais do que exceções ao princípio geral da autonomia privada e que tais restrições constituíam uma compressão exógena à econômica contratual, ditadas por circunstâncias excepcionais. Não comprometiam a autonomia privada em sua essência, mas apenas a limitavam em sua extensão. Com o advento do Código de Defesa do Consumidor, abriu-se caminho para uma cultura contratual antagônica: a autonomia privada e a intangibilidade do conteúdo do contrato e a relatividade de seus efeitos conformam-se atualmente a um conjunto de novos princípios como o da boa fé objetiva, do equilíbrio econômico e da função social do contrato. TEPEDINO, Gustavo; BARBOZA, Heloisa Helena; DE MORAES, Maria Celina Bodin. Código Civil interpretado conforme a Constituição da República. Rio de Janeiro: Renovar, 2006, vol. II, p. 7.

${ }^{88}$ STJ, REsp 972.436 - BA (2007/0179867-7), Rel. Ministra Nancy Andrighi, Brasília, julgado em 17 de março de 2009.

89 Art. 170 da Constituição Federal de 1988: A ordem econômica, fundada na valorização do trabalho humano e na livre iniciativa, tem por fim assegurar a todos existência digna, conforme os ditames da justiça social, observados os seguintes princípios: (...).

${ }^{90}$ GUERREIRO, José Alexandre Tavares. O Estado e a Economia dos Contratos Privados. In: Revista de Direito Mercantil Industrial, Econômico e Financeiro, vol. 31, Ano XVII, 1978, pp. 79 e 80 .
} 
afirmação, conforme demonstra TAVARES GUERREIRO, de que a livre iniciativa não constitui uma liberdade jurídica absoluta, mas sim relativa, condicionada ao princípio maior da promoção do desenvolvimento nacional e da justiça social.

Conforme se vê, a autonomia da vontade, em que pese não estar prevista expressamente no Código Civil de 2002, é considerada por todos como um valor fundamental, que tem destaque principalmente na vida privada. Além disso, possui respaldo também na ordem constitucional, observados certos limites e direcionada a um fim específico.

É sabido que essa autonomia nem sempre está presente nas relações, mas via de regra, ela não só deve como precisa estar presente. O indivíduo, sendo capaz de guiar suas próprias vontades, deve ter a oportunidade de dela fazer uso.

\subsection{Princípio da tipicidade $X$ princípio da autonomia da vontade}

Muito se questiona se a adoção do princípio da tipicidade societária limita a aplicação do princípio da autonomia da vontade, por vincular os agentes à escolha de um dos tipos definidos em lei.

Conforme explica PONTES DE MIRANDA:

Em verdade, ainda que amplamente, o direito limita a classe dos atos humanos que podem ser juridicizados. Mundo fático e mundo jurídico não são coextensivos. Noutros termos: somente dentro de limites prefixados, podem as pessoas tornar jurídicos atos humanos e, pois, configurar relações jurídicas e obter eficácia jurídica. A chamada "autonomia de vontade", o auto-regramento, não é mais do que "o que ficou às pessoas." Há situações que predeterminam relações jurídicas, sem que as pessoas possam evitá-las ou modificá-las.

(...) O que caracteriza o auto-regramento da vontade é poder-se, com ele, compor o suporte fático dos atos jurídicos com o elemento nuclear da vontade. Não importa em que ramo do direito ${ }^{91}$.

\footnotetext{
${ }^{91}$ MIRANDA, Pontes de. Tratado de Direito Privado. Parte Geral. Rio de Janeiro: Editor Borsoi, $3^{\mathrm{a}}$ edição, 1970, Tomo III, pp. 55 e 56.
} 
Ao mencionar os princípios da liberdade de contratar e da autonomia da vontade, PONTES DE MIRANDA os classifica como não sendo (nem de longe) absolutos, o que significa que esses princípios sofrem limitações. Segundo o autor, "a própria existência de tipos de negócios jurídicos limitaos. Limita-os, também, a natureza cogente (ius cogens) de certas regras",92.

A questão da cogência das normas está intrinsecamente relacionada ao princípio da autonomia da vontade e de sua aplicação às relações jurídicas. Fazendo-se uma diferenciação das normas cogentes e das normas dispositivas, PONTES DE MIRANDA explica:

O direito cogente, que é o que limita o auto-regramento da vontade, opera impositiva ou proibitivamente; de maneira que as pessoas têm de fazer ou de não fazer (no sentido mais largo); o que elide qualquer escolha, ainda quando a regra jurídica cogente contenha a alternativa de fazer isso ou aquilo; ou de não fazer isso, ou de não fazer aquilo; ou de fazer isso (ou aquilo), ou de não fazer aquilo (ou isso); ou vice versa.

Quando a regra jurídica é supletiva, isto é, estabelece que se entenda disposto a (ius dispositivum) se não foi disposto não-a, não se limita o auto-regramento da vontade: tais regras jurídicas, ditas regras dispositivas, deixam incólume o autoregramento da vontade ${ }^{93}$.

Desta forma, pode-se dizer que as normas cogentes, ou seja, de observância obrigatória, podem significar uma limitação ao princípio da autonomia da vontade. Mais adiante, no item referente à adoção de cláusulas atípicas no contrato de sociedade e de seus limites, também se abordará a questão da cogência das normas.

No que se refere especificamente à relação entre a definição de tipos e a autonomia da vontade, ao tratar das formas sob as quais os tipos se constroem (tipicidade aberta e tipicidade fechada), JULIANA KRUEGER PELA entende que em ambos os casos a tipicidade revela-se como uma limitação à autonomia privada. Entretanto, observa uma diferença de grau e função entre a limitação operada em cada caso. Segundo a autora, a diferença quanto ao grau parece intuitiva e bastante nítida, na medida em

\footnotetext{
${ }^{92}$ MIRANDA, Pontes de. Tratado de Direito Privado. Parte Geral. Rio de Janeiro: Editor Borsoi, $3^{\mathrm{a}}$ edição, 1970, Tomo III, pp. 63 e 64.

${ }^{93}$ MIRANDA, Pontes de. Tratado de Direito Privado. Parte Geral. Rio de Janeiro: Editor Borsoi, $3^{\mathrm{a}}$ edição, 1970, Tomo III, pp.60 e 61.
} 
que a tipicidade de origem legal restringe de forma mais incisiva a autonomia privada se comparada à tipicidade de origem social. Essa diferença de grau decorre da própria função desempenhada pela tipicidade em cada caso. ${ }^{94}$

Na mesma linha de entendimento, fazendo referência ao código civil italiano, PAOLO SPADA revela:

Solitamente abbinata alla enunciazione del principio della tipicità, si riscontra l'affermazione che tale principio derogherebbe o limiterebbe l'operatività del postulado fondamentale del diritto privato, cioè dell'autonomia privata $\mathrm{e}$, in particolare, di quella sua specificazione strutturale che l'art. 1322 c.c. chiama autonomia contractuale. ${ }^{95}$

Segundo PONTES DE MIRANDA, "a lei não deixa, inteiramente, à vontade dos interessados configurar as relações jurídicas”. Em diversas situações, a lei preestabelece as relações de modo claro e irremovível, havendo uma cogência absoluta e, em outras, cria tipos de relações jurídicas dentre as quais se pode escolher o que melhor convém, permitindo a escolha entre tipos de relações jurídicas, respeitados os limites, isto é, o número clauso de tipos (cogência relativa) ${ }^{96}$.

No entendimento de RACHEL SZTAJN, "afirmar que o sistema é fechado e que as sociedades constituem, em suas diferentes estruturas, um elenco taxativo - numerus clausus - significa dizer que a autonomia privada sofre limitações num dos campos em que, sempre, sua força criadora se fez sentir de maneira intensa"97.

A maioria dos autores, no entanto, alega que os dois princípios podem conviver em harmonia, já que o princípio da autonomia da vontade se aplica no âmbito interno do tipo societário escolhido.

Como bem explica JOSÉ LAMARTINE CORRÊA DE OLIVEIRA,

\footnotetext{
94 PELA, Juliana Krueger. As Golden Shares no Direito Brasileiro. São Paulo: Quartier Latin, 2012 , p. 107.

${ }^{95}$ SPADA, Paolo. La TIpicità delle Società. Padova: CEDAM, 1974, p. 6.

${ }^{96}$ MIRANDA, Pontes de. Tratado de Direito Privado. Parte Geral. Rio de Janeiro: Editor Borsoi, $3^{\text {a }}$ edição, 1970, Tomo III, p.56.

97 SZTAJN, Rachel. Contrato de Sociedade e Formas Societárias. São Paulo: Saraiva, 1989, Introdução, p. VI.
} 
Esse princípio do numerus clausus não destrói, porém, os princípios básicos da liberdade de autodeterminação e da autonomia da vontade. Poderíamos, antes, dizer que se trata de uma concretização de tais princípios básicos, embora contenha simultaneamente e sem paradoxo uma limitação. A lei limita ao enumerar uma série de tipos fora dos quais não pode haver pessoa jurídica. Como regra geral, porém, há, dentro do quadro da lei, liberdade de escolha do tipo. Essa liberdade de escolha sofre duas exceções, como explica Fabricius: os casos de determinação legal do tipo e os de limitação legal do tipo. Nos casos de determinação legal do tipo, a lei, para efetivação de uma finalidade específica, prescreve de modo cogente determinada forma jurídica, excluindo a liberdade de escolha de modo total, ou pelo menos limitando-a consideravelmente ${ }^{98}$.

Nesse sentido, MARCELO VON ADAMEK, após citar JOSÉ LAMARTINE CORREAA DE OLIVEIRA, complementa:

Isto porque, segundo explica Berardino Libonati, "o princípio da tipicidade não é rígido a ponto de impedir os sócios de aportarem modificações ao modelo legal eleito. Se, pois, a autonomia dos sócios resulta comprimida, no que diz respeito à escolha do tipo, a um daqueles predispostos pela lei, essa pode, porém, desenvolver-se no âmbito interno do tipo eleito, através da adoção de cláusula atípica até mesmo em derrogação à disciplina legal. ${ }^{99}$

Para EMILIO BETTI, para que surjam consequências jurídicas do exercício da autonomia da vontade, cabe à ordem jurídica reconhecê-lo e tal reconhecimento ou recepção não se confunde com uma atribuição aos particulares de criar normas jurídicas. Segundo o autor, consiste, ao contrário, no poder de identificar e escolher dentre as estruturas previstas nas normas jurídicas aquela que mais ou melhor atende aos interesses dos particulares. ${ }^{100}$

Há ainda quem entenda que a autonomia da vontade não é afastada, na medida em que o agente possui a opção de escolha do tipo societário que mais se adequa às suas necessidades. Nesse sentido, JULIANA KRUEGER PELA expõe que, na tipicidade de origem legal ou tipicidade fechada, “o

\footnotetext{
${ }^{98}$ OLIVEIRA, José Lamartine Corrêa. A Dupla crise da Pessoa Jurídica. São Paulo: Saraiva, 1979 , p. 57.

${ }^{99}$ VON ADAMEK, Marcelo Vieira. Abuso de Minoria em Direito Societário (Abuso das Posições Subjetivas Minoritárias). Tese apresentada para a obtenção do grau de Doutor em Direito Comercial pela Faculdade de Direito da USP, sob a orientação do Prof. Dr. Erasmo Valladão Azevedo e Novaes França. 2010, p. 319.

${ }^{100}$ BETTI, Emilio. Teoria Geral do Negócio Jurídico. Tradução de Fernando de Miranda. Coimbra: Coimbra Editora, 1969. Tradução de: Teoria General del Negozio Giuridico. $2^{\mathrm{a}}$ ed, 1950, v.1, p. 101. Apud PELA, Juliana Krueger. As Golden Shares no Direito Brasileiro. São Paulo: Quartier Latin, 2012, p. 103.
} 
exercício da autonomia privada restringe-se, nessa hipótese, à escolha do modelo mais adequado aos interesses das partes e às circunstâncias do caso". Desta forma, há liberdade para eleição do tipo, mas inexiste liberdade para a fixação ou alteração de seu conteúdo ${ }^{101}$.

PONTES DE MIRANDA também trata do exercício da autonomia dentro de limites ao expor que "não há autonomia absoluta ou ilimitada da vontade; a vontade tem sempre limites, e a alusão à autonomia é alusão ao que se pode querer dentro desses limites". ${ }^{102}$

Em síntese, apesar de alguns autores alegarem que o princípio da autonomia da vontade está presente no âmbito da escolha do tipo societário, é certo que para a escolha de um tipo não previsto no sistema da tipicidade fechada, a autonomia é atenuada, de forma que esta está longe de ser absoluta.

${ }^{101}$ PELA, Juliana Krueger. As Golden Shares no Direito Brasileiro. São Paulo: Quartier Latin, 2012, p. 107.

${ }^{102}$ MIRANDA, Pontes de. Tratado de Direito Privado. Parte Geral. São Paulo: Editora Revista dos Tribunais, $3^{\text {a }}$ edição, 1984, Tomo XXXVIII, p. 39. 


\section{O contrato de sociedade}

\subsection{Conceito}

É mediante a manifestação de vontade de duas ou mais pessoas que se configura um contrato de sociedade ${ }^{103}$. Essa manifestação, no entanto, não é o único elemento que deve ser considerado. É essencial que haja uma congregação de interesses, conforme explica PONTES DE MIRANDA:

O contrato de sociedade conclui-se para que duas ou mais pessoas se vinculem a prestações, versadas no interesse comum. Qualquer das prestações não pode ser só em proveito de quem a faz, ou de outra pessoa. A comunidade do interesse é elemento essencial ao conceito. ${ }^{104}$

O resultado da celebração de um contrato de sociedade é justamente a criação de uma sociedade por meio da qual as partes envolvidas se sujeitam a determinadas regras e a contribuir para a consecução do objeto pactuado, tendo como objetivo auferir resultados.

CARVALHO DE MENDONÇA dispõe que:

A sociedade comercial surge do contrato mediante o qual duas ou mais pessoas se obrigam a prestar certa contribuição para um fundo, o capital social, destinado ao exercício do comércio, com a intenção de partilhar os lucros entre si.

\section{(...)}

Da noção que aí fica, apura-se desde logo, esta singularidade: os sócios cooperam para o escopo comum, e, em lugar dos interesses antagônicos ou opostos, que se observam nos outros contratos, na de sociedade, todos os sócios se esforçam para o mesmo resultado, no qual estão empenhados. ${ }^{105}$

Qual é, no entanto, a relação do contrato de sociedade com a questão da tipicidade? É o que explica RACHEL SZTAJN:

\footnotetext{
${ }^{103}$ MIRANDA, Pontes de. Tratado de Direito Privado. Parte Geral. São Paulo: Editora Revista dos Tribunais, $3^{\mathrm{a}}$ edição, 1984, Tomo XLIX, p. 11.

${ }^{104}$ MIRANDA, Pontes de. Tratado de Direito Privado. Parte Geral. São Paulo: Editora Revista dos Tribunais, $3^{\text {a }}$ edição, 1984, Tomo XLIX, p. 12.

105 MENDONÇA, José Xavier Carvalho de. Tratado de Direito Comercial Brasileiro. Rio de Janeiro: Livraria Freitas Bastos, $6^{\text {a }}$ edição (revista por Roberto Carvalho de Mendonça), 1963, vol. III, p. 14.
} 
Em face do contrato de sociedade a questão da tipicidade se põe no plano da eleição entre tomar a descrição dos elementos definidores do contrato como conceitual ou tipológica. A opção pela definição implica aceitar que o modelo se identifica por elementos mínimos que, não presentes, impedem que o contrato seja considerado sociedade. De outro lado, se a escolha é a definição tipológica, há que se aumentar o número de elementos caracterizadores do contrato indefinidamente. $^{106}$

\subsection{Contrato plurilateral}

O estudo do contrato de sociedade pressupõe o exame da natureza do ato constitutivo de uma relação societária. A natureza dessa relação é fundamental para o tema da tipicidade societária, já que a ideia de sociedade como contrato envolve, de forma inseparável, o aspecto da voluntariedade e da liberdade dos indivíduos na estipulação das disposições sociais.

As teorias que embasam essa discussão se dividem em dois grupos: as teorias institucionalistas e as contratualistas.

De um modo geral, a teoria institucionalista ${ }^{107}$ teve origem após o processo de concentração industrial, iniciado no fim do século XIX/começo do século XX, o que levou à afirmação, por muitos, de que as macroempresas da época envolviam o interesse público, ultrapassando a esfera contratual privada, tendo surgido, portanto, a teoria da natureza institucional da sociedade ${ }^{108}$. Um dos pioneiros desta teoria foi WALTHER RATHENAU, que dizia que a empresa não era mais uma organização de direito privado, mas um fator da economia nacional a serviço de interesses públicos $^{109}$.

106 SZTAJN, Rachel. Contrato de Sociedade e Formas Societárias. São Paulo: Saraiva, 1989, Introdução, p. 56.

${ }^{107}$ Conforme explica Erasmo Valladão, dentre as categorias das teorias institucionalistas, a mais conhecida é a "teoria da empresa em si", abordada inicialmente por autores alemães. O autor aponta como outras teorias: a "teoria da pessoa em si", a "teoria do direito da empresa acionária" e a "teoria da instituição".

108 LAMY FILHO, Alfredo e PEDREIRA, José Luiz Bulhões (coordenadores). Direito das Companhias. Rio de Janeiro: Editora Forense, 2009, vol. I, p. 83.

${ }^{109}$ FRANÇA, Erasmo Valladão Azevedo e Novaes. Conflito de Interesses nas Assembleias de S.A. São Paulo: Malheiros, 1993, p. 22. 
Até hoje, a classificação da companhia como instituição é utilizada para fundamentar diversos aspectos ${ }^{110}$.

Contudo, conforme explicam LAMY FILHO E BULHÕES PEDREIRA "a teoria institucional da companhia não fornece, todavia, conceitos e princípios para a interpretação e aplicação da lei de sociedade por ações.",111

TAVARES GUERREIRO ensina que tradicionalmente o nosso direito sempre considerou a sociedade como contrato e menciona que ASCARELLI formulou a genial teoria de que o ato constitutivo da sociedade anônima se reveste de natureza de contrato plurilateral ${ }^{112}$.

No mesmo sentido que LAMY FILHO e BULHÕES DE PEDREIRA, para o autor "a teoria institucionalista é ainda insuficiente para explicar a natureza jurídica das relações que se passam entre a sociedade e cada um de seus acionistas". Além disso, como a adesão às regras da sociedade se dá de forma voluntária, caracteriza-se a celebração de um verdadeiro contrato, que tem natureza plurilateral.

As teorias contratualistas diferenciam-se das institucionalistas na medida em que nelas o interesse social reduz-se ao interesse comum dos sócios, ou seja, das partes contraentes. Assim, é conferida ampla liberdade de estipulação às partes para regular o funcionamento do mecanismo societário $^{113}$.

\footnotetext{
${ }^{110}$ Lamy Filho e Bulhões citam (i) o dever dos administradores e do acionista controlador de exercerem as funções e o poder tendo em conta, além de interesses dos acionistas, os de empregados da empresa, de consumidores de seus produtos e da economia nacional; (ii) a transferência dos acionistas para administradores profissionais do poder de orientar os destinos da companhia, em função de outros interesses que não apenas os dos acionistas; (iii) a subordinação dos direitos de acionistas aos "superiores interesses da empresa"; e (iv) a possibilidade de ampla modificação desses direitos. LAMY FILHO, Alfredo e PEDREIRA, José Luiz Bulhões (coordenadores). Direito das Companhias. Rio de Janeiro: Editora Forense, 2009, vol. I, p. 85.

${ }^{111}$ LAMY FILHO, Alfredo e PEDREIRA, José Luiz Bulhões (coordenadores). Direito das Companhias. Rio de Janeiro: Editora Forense, 2009, vol. I, p. 88.

${ }^{112}$ GUERREIRO, José Alexandre Tavares. O Estado e a Economia dos Contratos Privados. In: Revista de Direito Mercantil Industrial, Econômico e Financeiro, vol. 31, Ano XVII, 1978, p. 81.

${ }_{113}$ FRANÇA, Erasmo Valladão Azevedo e Novaes. Conflito de Interesses nas Assembleias de S.A. São Paulo: Malheiros, 1993, pp. 35, 36 e 49.
} 
No âmbito da teoria contratualista, ASCARELLI foi idealizador de uma constatação que muito contribuiu para dirimir certas deficiências da teoria: a ideia de que o contrato de sociedade é plurilateral.

A noção de contrato plurilateral se opõe à dos contratos bilaterais e se distingue, conforme ensina ASCARELLI: “(a) pela possibilidade de participação de mais de duas partes; (b) pelo fato de que, quanto a todas essas partes, decorrem do contrato, quer obrigações, de um lado, quer direitos, de outro."114

No contrato plurilateral, assim como nos contratos bilaterais, todas as partes envolvidas são titulares de direitos e de obrigações.

No entanto, os contratos plurilaterais, conforme ensina ASCARELLI, aparecem como contratos com comunhão de fim, e cada uma das partes obriga-se, de fato, para com todas as outras, e para com todas as outras adquire direitos, o que torna natural a coordenação em torno de um escopo comum. ${ }^{115}$

HAROLDO VERÇOSA e RACHEL SZTAJN complementam, ao mencionarem que:

A companhia, como as demais sociedades, é um contrato plurilateral. Admite a participação de mais de duas partes. Desse contrato resultam direitos e obrigações para todos os participantes. Mas o contrato de sociedade é, ainda, um contrato de organização, de cooperação, de comunhão de escopo e que, por ser de estrutura aberta, admite a variabilidade do número de partes ${ }^{116}$.

Outra diferença importante se refere ao fato de que "nos contratos bilaterais, as prestações de cada parte se apresentam numa relação jurídica de equivalência, substituindo-se reciprocamente, no patrimônio de cada uma". Enquanto isso, no contrato plurilateral, ao contrário "as prestações de cada parte não se apresentam, consideradas isoladamente, numa relação de

\footnotetext{
114 ASCARELLI, Tullio. Problemas das Sociedades Anônimas e Direito Comparado. São Paulo: Saraiva, 1945, p. 374.

115 ASCARELLI, Tulio. Problemas das Sociedades Anônimas e Direito Comparado. São Paulo: Saraiva, 1945, p. 394.

${ }^{116}$ VERÇOSA, Haroldo Malheiros Duclerc; SZTAJN, Rachel. A Incompletude do Contrato de Sociedade. In: Revista de Direito Mercantil Industrial, Econômico e Financeiro, Ano XLII, vol. 131, 2003, p. 14.
} 
equivalência; essa relação existe, porém, entre as obrigações e os direitos de cada parte e as de todas as demais, ou seja, levando em conta obrigações e direitos de cada parte, perante todas as demais." $" 117$

Vale, ainda, mencionar que na teoria de ASCARELLI o contrato de sociedade constitui apenas uma das espécies de contratos plurilaterais (a mais relevante), não sendo, no entanto, a única ${ }^{118}$.

Assim, ao se entender que o ato constitutivo da sociedade tem natureza contratual, é necessário atribuir-lhe caráter privado, fornecendo aos seus integrantes autonomia suficiente para que seus anseios e vontades possam ser refletidos no desenvolvimento da sociedade.

\subsection{Contrato típico}

Assumida a acepção do ato constitutivo da sociedade como contrato plurilateral, passa-se a análise de sua tipicidade. O contrato de sociedade é um contrato típico?

O artigo 981 do Código Civil de 2002 dispõe:

Celebram contrato de sociedade as pessoas que reciprocamente se obrigam a contribuir, com bens ou serviços, para o exercício de atividade econômica e a partilha, entre si, dos resultados.

Dessa descrição de contrato de sociedade, surge a seguinte questão: o artigo 981 descreve um tipo, ou seja, um modelo de estrutura negocial à qual se ligam efeitos jurídicos ${ }^{119}$ ? Em outras palavras, observado o conceito de tipicidade, é possível afirmar que ele se aplica na descrição contida nos artigos 1.363 do Código Civil de 1916 e 981 do Código Civil de 2002 ?

\footnotetext{
117 ASCARELLI, Tulio. Problemas das Sociedades Anônimas e Direito Comparado. São Paulo: Saraiva, 1945, p. 402.

118 Ascarelli analisa dois possíveis tipos de organização, correspondentes à sociedade e à associação. Esta diversidade, segundo ele, "corrobora a oportunidade de os contratos plurilaterais serem encarados como uma espécie particular no âmbito da categoria geral dos contratos". Assim, "o contrato de sociedade constitui, por seu turno, a subespécie praticamente mais importante, mas não a única, dos contratos plurilaterais".

${ }^{119}$ SZTAJN, Rachel. Contrato de Sociedade e Formas Societárias. São Paulo: Saraiva, 1989, p. 54.
} 
Para RACHEL SZTAJN, ao se referir ao artigo 1.363 do Código Civil de 1916, não há dúvida de que há certa estrutura definida em seu texto. ${ }^{120}$ A professora ensina:

Portanto, poder-se-á dizer que o contrato de sociedade, mais do que um tipo fechado, está, no art. 1.363 do Código Civil, a indicar a existência de uma estrutura conceitualmente típica, isto é, constitui um tipo abstrato que se presta a um sem-número de estipulações entre os contratantes, todas reconduzidas à estrutura abstrata conceituada naquele dispositivo legal ${ }^{121}$.

Nesse aspecto, se considerarmos que o atual artigo 981 é equivalente ao artigo 1.363 do Código Civil de 1916, percebemos a existência de uma figura conceitualmente típica, que dá origem a diversos subtipos ou espécies de contratos de sociedade.

Nesse sentido, a professora conclui:

Se contratos nominados são típicos, por instrumentalizarem, com as normas informadoras, um tipo de operação econômica socialmente típico, afirma-se que o contrato de sociedade é um dos contratos típicos disciplinados em lei. Entretanto, tal contrato típico pode apresentar manifestações concretas sob distintas estruturas, mantendo o núcleo central básico: comunhão de escopo e exercício de atividade para alcançar tal fim. A tipicidade do contrato de sociedade é regra dos mais diversos ordenamentos jurídicos, seja ela funcional, estrutural ou formal.

Desta forma, dada a previsão e a descrição do contrato de sociedade em dispositivo legal específico, conclui-se pelo seu caráter típico. Importante mencionar que está se falando aqui da tipicidade do contrato de sociedade, o que não se confunde com os diversos tipos societários dele derivados.

${ }^{120}$ SZTAJN, Rachel. Contrato de Sociedade e Formas Societárias. São Paulo: Saraiva, 1989, p. 56.

${ }^{121}$ SZTAJN, Rachel. Contrato de Sociedade e Formas Societárias. São Paulo: Saraiva, 1989, p. 54. 


\title{
4. Características dos tipos societários
}

\subsection{Conjuntura socioeconômica}

Em diversas partes do presente trabalho é dado destaque ao fato de que os tipos societários não são mera criação do legislador. Muito além, eles são imaginados a partir de uma determinada conjuntura, ou seja, são construções a partir de necessidades concretas. Há, assim, uma intensa interdependência entre a tipificação e os arranjos de interesses da vida em sociedade.

\section{Nessa linha dispõe GANDARA:}

En sus trazos generales y a los fines que ahora se persiguen sigue siendo válido, en cuanto pone básicamente de manifiesto cómo las instituciones que integran el sistema económico actual no son por lo general producto de la invención del legislador, sino fórmulas organizativas creadas por y para el tráfico, como formas de titularidad para tipos de actividad específicos. De ahí que cada forma social aparezca destinada a realizar una función diversa en el ámbito del sistema productivo.

(...) Se da así una interdependencia que es ya una constante en el sector de producción autonómica del Derecho: para la prosecución de intereses específicos, los particulares elaboran estructuras de actividad adecuadas, desde un punto de vista histórico y racional, a esa finalidad. Todo el complicado proceso de tipificación de la vida social descansa básicamente sobre este binomio "interéstipo de actividad" que presupone necesariamente una opción - elección, individualización y utilización - respecto de los instrumentos técnicos exigidos por el núcleo de intereses en juego. ${ }^{122}$

Ao tratar dos diversos tipos de sociedades, CARVALHO DE MENDONÇA faz a seguinte ressalva:

\begin{abstract}
Antes de passarmos adiante, convém dizer que a origem histórica dessas sociedades que ficam enumeradas, não é a mesma. Cada um desses tipos se desenvolveu sob a pressão de necessidades diversas e a influência de um sobre o outro, trazendo modificações recíprocas, somente se deu muito tempo depois. ${ }^{123}$
\end{abstract}

${ }^{122}$ GANDARA, Luis Fernandez de la. La Atipicidad en Derecho de Sociedades. Zaragoza: Pórtico, [s.d.], p. 31.

${ }^{123}$ MENDONÇA, José Xavier Carvalho de. Tratado de Direito Comercial Brasileiro. Rio de Janeiro: Livraria Freitas Bastos, $6^{a}$ edição (revista por Roberto Carvalho de Mendonça), 1963, vol. III, p. 60 . 
A determinação do conceito de empresa, no campo do Direito, deve ser precedida da definição da empresa econômica. O Direito é tradução da vida social nos seus múltiplos aspectos, inclusive o econômico, e, por isso, o fenômeno jurídico não pode ser fixado senão à luz de seus pressupostos, donde a utilidade de examinar o conceito econômico de empresa, tal como se formou no tempo e é hoje dominante ${ }^{124}$.

\section{Da mesma forma, RACHEL SZTAJN ensina que:}

Os tipos resultam de determinados comportamentos sociais geralmente observados em determinada coletividade e, subsequentemente, na medida em que se alarga sua aplicação a outras coletividades, se espraia sobre outras, podem converter-se em normas socialmente aceitas e, finalmente, em normas jurídicas que passarão a reger um certo comportamento social, dito então legalmente típico. ${ }^{125}$

As formas e os tipos de sociedades sempre representaram uma resposta às condições conjunturais socioeconômicas da época em que surgiram. Logo, a modelagem dos institutos jurídicos tem por suporte fático a realidade, a vida da coletividade; não são as normas que modelam os fatos humanos $^{126}$.

As normas servem, portanto, para orientar os comportamentos, mas devem sempre estar pautadas nos anseios e nas circunstâncias surgidas em determinado local, em um determinado período.

No mesmo sentido entende GANDARA:

Hoy es doctrina pacíficamente admitida, que la aparición de las sociedades mercantiles representa la respuesta técnico-jurídica a las necesidades económicas y sociales del tráfico, en momento históricos diferenciados. ${ }^{127}$

Dada essa necessidade de adaptação do direito à realidade, há quem entenda que conceber o sistema como fechado poderia vir a representar o engessamento dos modelos societários e o consequente atraso no acompanhamento da evolução das relações.

${ }^{124}$ MARCONDES, Sylvio. Problemas de Direito Mercantil. São Paulo: Max Limonad, 1970, p. 1. ${ }^{125}$ SZTAJN, Rachel. Contrato de Sociedade e Formas Societárias. São Paulo: Saraiva, 1989, p. 19.

126 SZTAJN, Rachel. Contrato de Sociedade e Formas Societárias. São Paulo: Saraiva, 1989, Introdução, p. VII.

127 GANDARA, Luis Fernandez de la. La Atipicidad en Derecho de Sociedades. Zaragoza: Pórtico, [s.d.], p. 30. 
É essa a preocupação central que tem RACHEL SZTAJN na parte introdutória de sua obra clássica sobre o tema. Tamanha a importância da questão, quando Contrato de Sociedade e Formas Societárias foi publicado (em uma época em que o sistema típico ainda tinha caráter aberto, na vigência do código anterior), RACHEL SZTJAN já tratava do tema de forma enfática.

Segundo a autora, "as estruturas jurídicas tradicionais parecem não ser suficientemente plásticas para evitar o aparecimento de novas formas associativas" $" 128$.

Indo além, ela acrescenta:

A congruência entre a organização econômica da empresa e as estruturas das sociedades, especialmente as das sociedades comerciais, deve ser investigada em sua plasticidade, e é possível que daí resulte a atipicidade das formas societárias, o que virá a exigir a revisão da disciplina proposta no Projeto de Código Civil para ajustá-lo ao substrato econômico real.

(...) A adequação das formas, aproximando o direito dos fatos econômicos e sociais que deve regular, depende de manter aberto o sistema, dando-lhe maleabilidade e condições de absorver o resultado da autonomia privada, ao menos naqueles campos em que, tradicionalmente, se admitem suas manifestações. ${ }^{129}$

\subsection{Elementos caracterizadores dos tipos}

Sendo necessário determinar quais são as características necessárias para a identificação dos tipos societários, esse subcapítulo se dispõe a explicar os principais critérios adotados pela doutrina, as críticas formuladas aos referidos critérios e as soluções apontadas por alguns autores.

Um dos critérios tradicionalmente apontados pela doutrina para a identificação de um tipo societário é o do grau de responsabilidade dos sócios. RACHEL SZTAJN explica essa afirmação:

${ }^{128}$ SZTAJN, Rachel. Contrato de Sociedade e Formas Societárias. São Paulo: Saraiva, 1989, Introdução, p. V.

${ }^{129}$ SZTAJN, Rachel. Contrato de Sociedade e Formas Societárias. São Paulo: Saraiva, 1989, Introdução, p. VI. 
Usualmente se faz a determinação dos tipos societários com base em um só elemento caracterizador, a responsabilidade dos sócios. O binômio responsabilidade $v s$. irresponsabilidade ou responsabilidade ilimitada $v s$. responsabilidade limitada, pretende-se seja suficiente para determinar-se a pertinência tipológica de uma sociedade concreta a um modelo legal. ${ }^{130}$

Esse é o critério adotado pelo direito inglês e, no Brasil, por diversos autores, entre eles, CARVALHO DE MENDONÇA:

A classificação mais prática e racional das sociedades comerciais é a adotada pelo sistema inglês, que não as discrimina sob designações particulares, porém, mediante o critério dos graus de responsabilidade dos sócios para com os credores sociais, ou melhor, sob o ponto de vista da garantia especial que oferecem a terceiros. A responsabilidade dos sócios nos seus diversos graus é o denominador comum da sociedade. ${ }^{131}$

PAOLO SPADA, utilizando-se dos ensinamentos de outros autores, é crítico desse critério, ao afirmar que o grau de responsabilidade do sócio é uma consequência de sua posição, e não um elemento descritivo. ${ }^{132}$ Veja-se o que diz o autor, fazendo referência a BERTO:

L'identificazione dei tipi a livello del regime dela responsabilità dei soci si fonda - per questo autore - su uma curiosa inversione di ragionamento, scambiando causa ed effetto, fenomeno principale e fenomeno conseguenziale.

Outro elemento bastante empregado por aqueles que visam identificar os elementos caracterizadores dos tipos societários se refere à distinção entre sociedades de pessoas e sociedades de capitais. CARVALHO DE MENDONÇA esclarece a utilização desse critério:

Fazem, também, a seguinte distinção, que não escapa à censura de ilógica, confundindo a sociedade com os sócios, pessoas distintas e independentes, e esquecendo-se de que todas as sociedades têm um capital expresso em dinheiro, garantia exclusiva dos credores sociais: sociedades de pessoas e sociedades de capitais, ou, o que dá no mesmo, sociedades por quotas e sociedades por ações,

\footnotetext{
${ }^{130}$ SZTAJN, Rachel. Contrato de Sociedade e Formas Societárias. São Paulo: Saraiva, 1989, Introdução, p. 19.

131 MENDONÇA, José Xavier Carvalho de. Tratado de Direito Comercial Brasileiro. Rio de Janeiro: Livraria Freitas Bastos, $6^{\text {a }}$ edição (revista por Roberto Carvalho de Mendonça), 1963, vol. III, p.60.

${ }^{132}$ SPADA, Paolo. La TIpicità delle Società. Padova: CEDAM, 1974, pp. 37 e 38.
} 
acrescentando-se a estas duas as sociedades de capital variável (as cooperativas). ${ }^{133}$

RUBENS REQUIÃO é um dos que adota, para o estudo dos particularismos dos vários tipos de sociedades comerciais, essa classificação entre sociedade de pessoas e de capitais devido, segundo ele, ao seu valor didático ${ }^{134}$.

Conforme explica SYLVIO MARCONDES “segundo esse sistema são sociedades de pessoas aquelas em que os sócios se escolhem tendo em consideração as suas qualidades pessoais, o que determina a predominância do intuitus personae no seu funcionamento". Já as sociedades de capitais seriam aquelas "em que somente a contribuição dos sócios é tomada em conta, de modo que qualquer pessoa delas pode fazer parte, sendo livremente transferíveis as ações que formam o seu capital". ${ }^{135}$

SYLVIO MARCONDES critica os critérios tradicionalmente utilizados referidos acima, pois acredita que eles não funcionam quando se trata dos tipos "de caráter misto". O autor acredita que nas classificações examinadas o critério de sistematização das sociedades é unilateral ${ }^{136}$, não sendo suficiente para resultar na exata posição de cada espécie ${ }^{137}$.

Explica-se: na classificação das sociedades pelo grau de responsabilidade dos sócios, as sociedades em comandita teriam o feitio misto, pois são de responsabilidade ilimitada para os comanditados e de responsabilidade limitada para os comanditários. Além disso, na classificação que divide as sociedades em sociedades de pessoas e de

\footnotetext{
133 MENDONÇA, José Xavier Carvalho de. Tratado de Direito Comercial Brasileiro. Rio de Janeiro: Livraria Freitas Bastos, $6^{\text {a }}$ edição (revista por Roberto Carvalho de Mendonça), 1963, vol. III, p.63.

${ }^{134}$ REQUIÃO, Rubens. Curso de Direito Comercial. 28a. edição. São Paulo: Saraiva, 2009, vol. I, p.433.

${ }^{135}$ MARCONDES, Sylvio. Problemas de Direito Mercantil. São Paulo: Max Limonad, 1970, p. 171.

136 Paolo Spada também defende que não se pode utilizar um único critério caracterizador. Em suas palavras: "Ovvero: quali sono i fattori tipizzanti dele subfattispecie societarie? Col che non diamo, naturalmente, per scontato che i critério d'identificazione siano costanti per tutti i tipi e neppure che ad ogni tipo presieda um solo criterio." SPADA, Paolo. La Tipicità delle Società. Padova: CEDAM, 1974, p. 27.

137 Toda essa discussão e a solução proposta estão contidas em: MARCONDES, Sylvio. Problemas de Direito Mercantil. São Paulo: Max Limonad, 1970, pp. 169 a 181.
} 
capitais, a comandita por ações pertence às primeiras em razão dos gerentes e às segundas quanto aos acionistas, assumindo também caráter misto. E, por fim, ele classifica a sociedade de responsabilidade limitada, como tipo intermediário entre as sociedades de nome coletivo e as sociedades anônimas.

Assim, como solução alternativa, SYLVIO MARCONDES defende que, para se estabelecer uma classificação dos tipos societários, devem ser levados em consideração os seguintes elementos: o capital e o trabalho. Nesse sentido, o autor entende que a contribuição do sócio à sociedade deve ser analisada sob dois pontos de vista: o patrimonial e o pessoal.

Prosseguindo, ele explica que a contribuição patrimonial de cada sócio pode ser limitada ou ilimitada, sendo no primeiro caso representada por quotas ou por ações. Já a contribuição pessoal pode assumir a mais variada extensão ou intensidade, desde a plena administração da sociedade até a simples fiscalização dos negócios sociais. Desta forma, ele divide os extremos de contribuição pessoal entre máximo e mínimo.

Assim, o esquema por ele proposto resta assim definido:

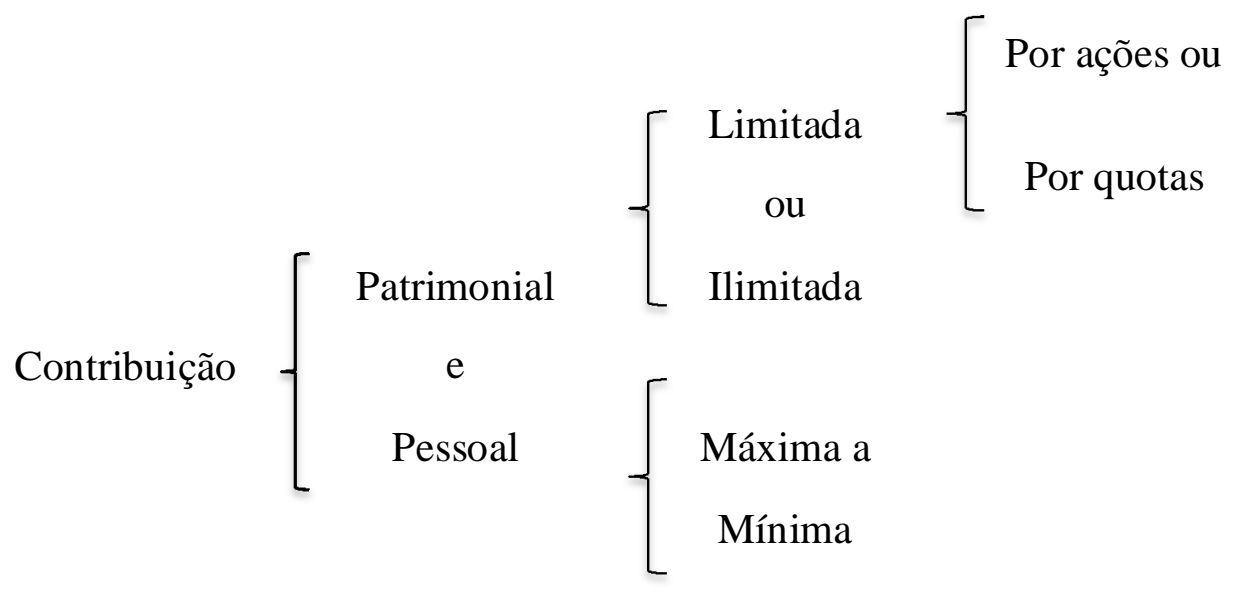

O esquema proposto, segundo SYLVIO MARCONDES:

Reúne os elementos capital e trabalho, para que se possa verificar a relação que guardam entre si; leva em conta, outrossim, a posição jurídica dos sócios, que Carvalho de Mendonça analisa de modo bipartido; e, finalmente, atende às 
modalidades que a affectio societatis, segundo Copper Royer, pode tomar, no exame da causa da obrigação de cada sócio, pela predominância do intuitus personae ou do intuitus pecuniae.

Em seguida, o autor se propõe a verificar se o esquema se ajusta às várias espécies de sociedade e a forma como se dá esse ajustamento.

RACHEL SZTAJN também entende que a definição não é tão simples e que eles são determinados por várias características, após a observação empírica de um grande número de fenômenos da espécie de forma a estabelecer-se, por abstração, um modelo. Compartilhando do mesmo entendimento de SYLVIO MARCONDES, ela entende que um só elemento classificador do tipo não pode oferecer as informações necessárias para a determinação do contrato concreto do tipo. ${ }^{138}$

Como solução, a autora afirma que o aumento do número de características tipificadoras, apesar de ser a solução mais simples, levaria à descrição do contrato concreto. Assim, ela propõe que, "a par da estrutura externa, aparente, do contrato ou do exercício da atividade, seja considerada a estrutura interna, não-transparente, para determinar as características tipificadoras das sociedades".

Adicionalmente, a autora acredita que também se deve adotar como critério de investigação a comparação entre as funções que os diferentes tipos de sociedade exerciam quando do seu aparecimento e as funções que têm hoje, para se identificar as razões de sua permanência no ordenamento jurídico ao lado dos novos tipos que surgem. ${ }^{139}$

\footnotetext{
${ }^{138}$ SZTAJN, Rachel. Contrato de Sociedade e Formas Societárias. São Paulo: Saraiva, 1989, Introdução, p. 20.

${ }^{139}$ SZTAJN, Rachel. Contrato de Sociedade e Formas Societárias. São Paulo: Saraiva, 1989, Introdução, p. 21.
} 


\section{Tipicidade societária no direito estrangeiro}

\subsection{No direito europeu}

\subsubsection{Direito italiano}

No direito italiano, assim como no direito brasileiro, os tipos de sociedades são taxativamente definidos, conforme se extrai do texto do artigo 2.249 do Codice Civile ${ }^{140}$.

$\mathrm{Na}$ verdade, nesse aspecto, o direito brasileiro se inspirou nas disposições no Codice Civile, ainda da época de Mussolini, legislação essa que, segundo afirma RACHEL SZTAJN, "servia de veículo para que o Estado fascista interferisse na atividade econômica, controlando-a". ${ }^{141}$

RACHEL SZTAJN, ao comparar o critério adotado no direito italiano com o sistema anterior, contemplado no Código Civil de 1916 e do Código Comercial, dispõe:

\footnotetext{
O legislador italiano ordena as disposições sobre sociedades de maneira a definir um elenco taxativo de tipos (não cuidou dos grupos como sociedades de sociedades, com contrato ou convenção escrita, mas, apenas, como resultado da participação de uma sociedade no capital de outras) e proíbe a criação de sociedades empresárias que não adotem uma das formas das sociedades tipificadas; não foi esta a orientação do legislador brasileiro, quer no Código Comercial quer no Código Civil. ${ }^{142}$
}

\footnotetext{
${ }^{140}$ Art. 2249 - Tipi di società.

Le società che hanno per oggetto l'esercizio di una attività commerciale devono costituirsi secondo uno dei tipi regolati nei capi III e seguenti di questo titolo.

Le società che hanno per oggetto l'esercizio di una attività diversa sono regolate dalle disposizioni sulla società semplice a meno che $i$ soci abbiano voluto costituire la società secondo uno degli altri tipi regolati nei capi III e seguenti di questo titolo.

Sono salve le disposizioni riguardanti le società cooperative e quelle delle leggi speciali che per l'esercizio di particolari categorie di imprese prescrivono la costituzione della società secondo un determinato tipo.

${ }^{141}$ DA FONSECA, Priscila M. P. Corrêa; SZTAJN, Rachel. Código Civil Comentado. Direito da Empresa. Coordenação de Álvaro Villaça Azevedo. São Paulo: Atlas, 2008, vol. XI, p. 145.

142 SZTAJN, Rachel. Contrato de Sociedade e Formas Societárias. São Paulo: Saraiva, 1989, Introdução, pp. 145 e 146.
} 
PAOLO SPADA, referindo-se ao direito italiano, informa que a alegação de que o direito das sociedades adota um sistema Typenzwang, ou seja, numerus clausus, é afirmação recorrente na literatura jurídica:

Che i tipi di società costituiscano un numero chiuso, che, di contro alla Typenfreiheit del diritto delle obbligazioni, viga, nel diritto delle società, un rigido Typenzwang, sono affermazioni ricorenti nella letteratura giuridica degli orinamenti continentali. ${ }^{143}$

No mesmo sentido, GANDARA dispõe que a tendência no ordenamento espanhol e no direito comparado a reconhecer a vigência de um sistema numerus clausus não corresponde a uma consagração formal do princípio pelo legislador, com exceção do direito italiano que, por meio do art. 2249 do Codice Civile introduziu um sistema de tipicidade taxativa, que é assim caracterizado pelo autor:

En cualquier caso las facultades concedidas a los particulares se limitan, en este sentido, únicamente a un ius electionis: no están autorizados para concluir contratos de sociedad diversos de los tipos dotados de una disciplina particular. El camino para la creación de nuevas formas societarias por los intervinientes está cerrado. ${ }^{144}$

Apesar da proximidade entre o direito italiano e o direito brasileiro no que diz respeito à matéria da tipicidade societária, RACHEL SZTAJN dispõe que a doutrina italiana entende que o artigo 1.322 do Codice Civile ampara a liberdade contratual e que, portanto, as partes podem celebrar contratos diferentes, no caso em que seus interesses sejam merecedores de tutela:

A doutrina italiana alertava que não convinha ater-se aos termos da norma citada, pois, invocado o princípio da autonomia contratual, chega-se ao reconhecimento de sociedades atípicas, mesmo porque os tipos legalmente previstos não esgotariam a noção geral de contrato de sociedade. O art. 1.322 do Código Civil italiano ampara a liberdade contratual, facultando às partes celebrar contratos diferentes dos tipificados, desde que destinados à realização de interesses merecedores de tutela, conforme o ordenamento jurídico.

\footnotetext{
${ }^{143}$ SPADA, Paolo. La Tipicità delle Società. Padova: CEDAM, 1974, p. 1.

144 GANDARA, Luis Fernandez de la. La Atipicidad en Derecho de Sociedades. Zaragoza: Pórtico, [s.d.], p. 79.
} 
A intromissão do legislador era temperada pela tutela de interesses particulares que não violassem a ordem pública, a moral e os bons costumes. ${ }^{145}$

Segundo a autora, o Código Civil de 2002, no entanto, não teria repetido essa norma, dando enfoque diferente ao tema, ao prever que a liberdade de contratar será exercida nos limites da função social do contrato (art. 421). ${ }^{146}$

Como o termo 'função social do contrato' é muito abrangente e admite interpretações extensas, não parece que o direito brasileiro tenha dado enfoque tão diferente ao tema no sentido de suprimir a atuação dos particulares. A liberdade de contratar de um modo geral, ainda que não absoluta, está presente em nosso ordenamento.

\subsubsection{Outros países}

Conforme explica GANDARA, devido ao clima ideológico liberal no qual se desenvolveu o processo codificador na Europa, os outros ordenamentos, inclusive o espanhol, não seguiram o mesmo caminho do direito italiano ${ }^{147}$ :

En los restantes ordenamientos falta una norma análoga a la del artículo 2249 C. civile de la cual pueda deducirse de forma inequívoca la inderogabilidad por vía negocial de las normas de identificación de las modalidades de operación societaria. La ausencia de disposiciones que consagren la presencia del principio de numerus clausus en la normativa societaria obedece, como es sabido, al clima ideológico liberal en que se desenvolvió el proceso codificador, que llevó directamente a la implantación de un sistema de libertad de asociación, entendido como posibilidad de invención de nuevas formas de sociedad por los propios interesados. Esta orientación liberal del legislador luce de forma clara en nuestro ordenamiento: el art. 122 C. comercio, al servirse de una fórmula puramente enunciativa - las compañías mercantiles se constituirán "por regla general" - no hace sino ratificar la dirección ideológica que había sido recogida inicialmente en la Ley de Bases aprobada por el D. de 20-9-1989 y más tarde consagrada en la Exposición de Motivos.

${ }^{145}$ DA FONSECA, Priscila M. P. Corrêa; SZTAJN, Rachel. Código Civil Comentado. Direito da Empresa. Coordenação de Álvaro Villaça Azevedo. São Paulo: Atlas, 2008, vol. XI, p. 145.

${ }^{146}$ DA FONSECA, Priscila M. P. Corrêa; SZTAJN, Rachel. Código Civil Comentado. Direito da Empresa. Coordenação de Álvaro Villaça Azevedo. São Paulo: Atlas, 2008, vol. XI, pp. 145 e 146.

${ }^{147}$ Todos os ensinamentos de GANDARA a respeito do direito europeu e dos outros países que serão analisados nesse item estão contidos em GANDARA, Luis Fernandez de la. La Atipicidad en Derecho de Sociedades. Zaragoza: Pórtico, [s.d.], pp. 78 - 88. 
O autor espanhol explica, ainda, que o restante dos ordenamentos europeus não se pronuncia nem a favor da adoção do princípio numerus clausus nem a favor da liberdade de invenção de tipos. Como exemplo, o autor cita os casos dos direitos suíço e alemão, pautados constitucionalmente pelo princípio da autodeterminação do sujeito jurídico:

Frente a estas dos posiciones extremas, representadas por el Derecho español y el italiano, los restantes ordenamientos europeos no se pronuncian de una forma abierta ni a favor del principio de numerus clausus ni a favor de la libertad de invención. Esta última solución parece venir acogida sin embargo tanto por razones sistemáticas como de carácter jurídico-constitucional. Así en los Derechos suizo y alemán, en los que, en base al principio de autodeterminación del sujeto jurídico reconocido en la Constitución Federal, se ha venido sosteniendo la facultad que ampara a los particulares para crear y explotar empresas comerciales e industriales bajo la forma jurídico-societaria que estimen más adecuada a sus necesidades. Y a esta misma solución se llega toda vez que el contrato de sociedad forma parte del Derecho de obligaciones dentro del cual rige, con carácter general, el principio de libertad contractual cuya aplicación supone la posibilidad de crear nuevos esquemas de organización. En uno y otro caso, la autonomía contractual parece excluir por incompatible con el sistema legislativo la existencia de un numerus clausus de formas sociales.

Analisando os ensinamentos de GANDARA, parece que a questão é simples: o direito italiano teria um caráter de tipicidade fechada, assim como o direito brasileiro atual, enquanto os outros ordenamentos seriam pautados pela autonomia privada e pela liberdade de contratar.

No entanto, a questão merece uma análise mais profunda. Em que pese não haver reconhecimento legislativo expresso de um sistema taxativo, na prática, a situação não é bem essa. GANDARA demonstra que, mesmo nesses ordenamentos, a pureza da liberdade de invenção não se deu nunca por duas razões: (i) o fato de que algumas sociedades destinadas a operar em setores econômicos de interesse nacional estariam subordinadas a autorização prévio do poder público ou (ii) a necessidade de se observar determinadas regras materiais e formais relativas à constituição das sociedades. Veja-se o que diz exatamente o autor: 
El cuadro legislativo que acaba de exponerse recoge los trazos fundamentales del ordenamiento positivo pero no expresa la situación real del derecho vigente. La pureza del sistema de libertad de invención no se ha dado nunca, ni siquiera en aquellos países en que su existencia descansa sobre un reconocimiento formal y expreso del legislador. La razón es doble: por un lado, la implantación, en forma más o menos generalizada, de un Konzessionssytem, por virtud del cual la constitución de sociedades destinadas a operar en sectores económicos de interés nacional vendría subordinada a la autorización previa de los poderes públicos. Por otro, en los ordenamientos en que no se imponen tales formalidades, la necesidad de observar determinadas reglas materiales y formales relativas a la constitución - el llamado sistema normativo (Normativsystem) consagrado hoy en la generalidad de los países -.

Assim, esses ordenamentos seriam pautados em "un principio de libertad "reglamentada" que, con posteridad a la codificación, ha dado lugar en los ordenamientos europeos continentales a un desarrollo legislativo interesante".

Conforme explica GANDARA, esse foi o caso do direito espanhol que, em razão da promulgação do novo regramento de registro mercantil (Reglamento del Registro Mercantil de 1956), optou-se por abandonar a solução consagrada no art. 123 do código de comércio espanhol, optando-se por uma concepção claramente restritiva, ao se limitar a proteção registral exclusivamente às sociedades "que se constituyan com arreglo a las disposiciones o formas del Código de Comercio o a Leyes especiales (art. 84)". O mesmo se daria com o direito suíço que, ao prever o requisito de inscrição registral, introduziu um sistema de controle preventivo já que somente as sociedades previstas em catálogo legislativo têm acesso à proteção registral.

Nos dois casos, portanto, foi "el propio legislador quien ha comenzado a abandonar paulatinamente las posiciones liberales del codificador histórico y a romper con el modelo de libertad de invención consagrado explícita o implícitamente en el derecho positivo". 


\subsection{Nos países da Common Law}

Nos países que adotam o sistema da Common Law a discussão quanto à tipicidade tem um enfoque diferente. Os autores costumam adotar uma abordagem distinta sobre o tema, discutindo, de forma genérica, questões relacionadas à liberdade de contratar em oposição à existência de regras cogentes. Expondo seus argumentos a favor ou contra a liberdade contratual, os autores fazem uso de argumentos e conceitos do Law and Economics, trazendo para a discussão um caráter mais econômico.

Não se está afirmando aqui que nos países que adotam a Common Law não existam definições de tipos societários delineados. Ocorre que não se tem notícia de uma definição típica do contrato de sociedade, tampouco de uma disposição que caracterize um sistema típico fechado de modelos societários.

No entanto, o estudo da discussão no âmbito da Common Law é importante para o tema abordado nesse trabalho, de forma a demonstrar se a adoção de um modelo que restringe a eleição de tipos societários é ou não benéfica.

Nesse sentido, quando os autores da Common Law tratam da liberdade contratual, é preciso fazer uso dos argumentos por eles trazidos, para se defender um sistema típico aberto. Da mesma forma, os argumentos utilizados por aqueles que defendem a existência de normas de observância obrigatória devem ser utilizados ao se acolher o sistema típico fechado.

Deste modo, a discussão sobre a tipicidade societária se assemelha à dos autores de países da Common Law, tendo as duas o objetivo de responder a mesma questão - o que funciona melhor: um sistema pautado pela autonomia da vontade ou um sistema composto por determinadas normas cogentes de modo a limitar a liberdade de escolha? 
Para explicar o debate que foi objeto da Columbia Law Review n. 89, será utilizada a classificação de $\mathrm{BEBCHUK}^{148}$. O autor chama aqueles que defendem uma liberdade geral de escolha de "deregulators", enquanto aqueles que defendem a imposição de limites a essa liberdade são denominados "regulators".

Outro ponto importante diz respeito à divisão que o autor faz entre a liberdade contratual na fase de constituição da sociedade (initial charter) e no momento de alteração do contrato de sociedade (charter amendment stage). Em sua opinião, a discussão é muito mais problemática quando se trata do segundo momento.

Os deregulators entendem que a sociedade deve ser vista como um nexus de contratos. Nesse sentido, eles argumentam que uma visão contratual da sociedade implica na possibilidade de as partes envolvidas terem liberdade total para modelarem seu próprio contrato. A função do direito societário seria facilitar esse processo dispondo de uma série de disposições padrão (nonmandatory standard-forms provisions) não obrigatórias, sendo as partes livres para adotar as disposições contratuais de acordo com suas vontades. O direito societário serviria também para regular as situações não descritas pelas partes no contrato de sociedade ${ }^{149}$. Seus principais representantes são FRANK EASTERBROOK e DANIEL FISCHEL $^{150}$.

De outro lado, os regulators MELVIN EISENBERG ${ }^{151}$, JEFFREY GORDON $^{152}$, JOHN COFFEE ${ }^{153}$, ROBERT CLARK $^{154}$, entre outros,

\footnotetext{
${ }_{148}$ BEBCHUK, Lucian Arye. The Debate on Contractual Freedom in Corporate Law. In: Columbia Law Review n. 89, 1989, p. 1399.

${ }^{149}$ BEBCHUK, Lucian Arye. The Debate on Contractual Freedom in Corporate Law. In: Columbia Law Review n. 89, 1989, p. 1397.

${ }^{150}$ EASTERBROOK, Frank H.; FISCHEL, Daniel R. The Corporate Contract. In: Columbia Law Review n. 89, 1989, pp. 1416 - 1448.

${ }^{151}$ EISENBERG, Melvin. The Structure of Corporation Law. In: Columbia Law Review n. 89, 1989 , pp. $1461-1525$.

${ }^{152}$ GORDON, Jeffrey N. The Mandatory Structure of Corporate Law. In: Columbia Law Review n. 89,1989 , pp. $1549-1598$.

${ }^{153}$ COFFEE, John C. The Mandatory/Enabling Balance in Corporate Law: an Essay on the Judicial Role. In: Columbia Law Review n. 89, 1989, pp. 1618 - 1691.

${ }_{154}$ CLARK, Robert. Contracts, Elites, and Traditions in the Making of Corporate Law. In: Columbia Law Review n. 89, 1989, pp. 1703 - 1747.
} 
apresentam visões, em diversos níveis, que são críticas à liberdade de contratar e apoiam a imposição de regras cogentes (mandatory rules).

Segundo explica BEBCHUK, os deregulators possuem argumentos mais fortes com relação ao momento de constituição da sociedade e de seu contrato inicial, enquanto os regulators apresentam argumentos mais fortes com relação à fase de alteração contratual ${ }^{155}$.

A discussão se baseia em dois argumentos: as externalidades (externality arguments) e a informação imperfeita (imperfect information arguments).

Quanto ao primeiro, argumenta-se que na presença de externalidades, o acordado privadamente pode ser socialmente ineficiente, já que as partes contratantes não levariam em conta os efeitos causados a terceiros. Assim, regras cogentes poderiam causar a aproximação a uma otimização social.

Gordon, por exemplo, entende que um regime de completa liberdade contratual no direito societário impõe externalidades negativas a outras partes que adotam disposições padrão, já que estas não teriam precedentes para avaliar as disposições alteradas livremente ${ }^{156}$. A adoção de cláusulas padrão, por sua vez, traria mais segurança a terceiros, que poderiam conhecer seu teor de antemão.

Os deregulators acreditam que esse argumento não deve prosperar, já que o interesse das partes contratantes é sempre maior. De qualquer forma, os deregulators entendem que a liberdade contratual não deve ser absoluta, pois certas situações muito específicas, excepcionalmente exigem um tratamento por normas cogentes (por exemplo, quando se trata de information disclosure).

155 BEBCHUK, Lucian Arye. The Debate on Contractual Freedom in Corporate Law. In: Columbia Law Review n. 89, 1989, p. 1400.

${ }^{156}$ GORDON, Jeffrey N. The Mandatory Structure of Corporate Law. In: Columbia Law Review n. 89,1989 , p. 1567. 
O segundo argumento, da informação imperfeita ${ }^{157}$, gera mais divergências do que o argumento das externalidades. Como a imposição de regras cogentes muitas vezes não envolve externalidades substanciais, esse argumento é a principal justificativa para a existência dessas regras ${ }^{158}$. Os regulators acreditam que a falta de informações pode afetar a constituição de uma sociedade. $\mathrm{O}$ argumento utilizado é de que os compradores de ações em uma oferta pública inicial geralmente não analisam ou acessam integralmente os aspectos da companhia. Consequentemente, os efeitos esperados de certas disposições contratuais não são totalmente refletidos no preço médio das ações ${ }^{159}$.

Ao defender a existência de determinadas regras cogentes, conclui

\section{KORNHAUSER:}

"Trust" permits the parties to contract more safely and cheaply, but only mandatory "trust" will do. Terms that the parties may later alter do not offer an adequate background against which to contract. Similarly, the parties cannot themselves resolve the coordination problems inherent in drafting multiple sets of contracts by defining the terms of their trust. They require a single set of terms upon which all can rely. Primary mandatory rules meet this basic need of corporate contracting. ${ }^{160}$

Assim, percebe-se que os argumentos trazidos pelos deregulators se aproximam daqueles utilizados por quem defende que a tipicidade societária é uma afronta à autonomia da vontade e à liberdade de contratar e que, portanto, um sistema livre seria mais adequado.

De outro lado, as teses trazidas pelos regulators, sobretudo a questão da existência de externalidades e do problema da informação imperfeita,

\footnotetext{
${ }^{157}$ Sobre esse ponto, Kornhauser critica a utilização, por Easterbrook e Fischel , da condição de full information como sendo fundamental na definição do contrato ideal. O autor explica as dificuldades envolvidas na definição do que seria full information. KORNHAUSER, Lewis A. The Nexus of Contract Approach to Corporations: A Comment on Easterbrook and Fischel. Columbia Law Review n. 89, 1989, pp. 1455-1457.

158 BEBCHUK, Lucian Arye. The Debate on Contractual Freedom in Corporate Law. In: Columbia Law Review n. 89, 1989, p. 1406.

159 BEBCHUK, Lucian Arye. The Debate on Contractual Freedom in Corporate Law. In: Columbia Law Review n. 89, 1989, p. 1406.

${ }^{160}$ KORNHAUSER, Lewis A. The Nexus of Contract Approach to Corporations: A Comment on Easterbrook and Fischel. Columbia Law Review n. 89, 1989, p. 1460.
} 
são fortes argumentos para entender que um sistema típico taxativo é importante para o desenvolvimento do mercado.

Daí a importância de se tomar essa discussão como parâmetro e de tentar aproximá-la para o tema deste trabalho. 


\section{Tipicidade societária no Brasil}

Analisada a questão no âmbito do direito estrangeiro, resta verificar como a tipicidade societária é tratada no Brasil.

\subsection{Evolução legislativa}

O Código Civil de 1916 e o Código Comercial davam um tratamento diverso do atual para a questão da tipicidade societária. O sistema, ao contrário do atual, era aberto.

Veja-se o que RACHEL SZTAJN fala sobre o sistema anterior:

Finalmente, analisando o sistema societário delimitado pelas normas do Código Civil e do Código Comercial, visa-se concluir que não se pode tomá-los como sistemas fechados e que, portanto, seriam admissíveis as formas atípicas de sociedades, ao contrário do que ocorre no direito italiano e no Projeto de Código Civil brasileiro. ${ }^{161}$

Ainda no mesmo sentido, a autora explica que o texto do artigo 1.363 do Código Civil de 1916 adotava uma definição conceitual abstrata, e não uma definição tipológica. Assim, o contrato de sociedade permitia uma variabilidade de esquemas organizacionais que eram definidos por conjuntos de regras imperativas ou cogentes e por regras dispositivas, determinando tipos de formas do contrato de sociedade. ${ }^{162}$

O artigo 1.363 e seguintes do Código Civil de 1916 e o artigo 305

Código Comercial previam o seguinte:

Art. 1.363. Celebram contrato de sociedade as pessoas, que mutualmente se obrigam a combinar seus esforços ou recursos, para lograr fins comuns.

Art. 1.364. Quando as sociedades civis revestirem as formas estabelecidas nas leis comerciais, entre as quais se incluí a das sociedades anônimas, obedecerão aos respectivos preceitos, no em que não contrariem os deste Código; mas serão inscritas no registro civil, e será civil o seu foro.

${ }^{161}$ SZTAJN, Rachel. Contrato de Sociedade e Formas Societárias. São Paulo: Saraiva, 1989, Introdução, p. VII.

${ }^{162}$ SZTAJN, Rachel. Contrato de Sociedade e Formas Societárias. São Paulo: Saraiva, 1989, Introdução, p. 56. 
Art. 1.365. Não revestindo nenhuma das formas do artigo antecedente, a sociedade reger-se-á pelo que neste capítulo se prescreve.

Art. 305 - Presume-se que existe ou existiu sociedade, sempre que alguém exercita atos próprios de sociedade, e que regularmente se não costumam praticar sem a qualidade social.

Desta natureza são especialmente:

1 - Negociação promíscua e comum.

2 - Aquisição, alheação, permutação, ou pagamento comum.

3 - Se um dos associados se confessa sócio, e os outros o não contradizem por uma forma pública.

4 - Se duas ou mais pessoas propõem um administrador ou gerente comum.

5 - A dissolução da associação como sociedade.

6 - O emprego do pronome nós ou nosso nas cartas de correspondência, livros, fatura, contas e mais papéis comerciais.

7 - $\mathrm{O}$ fato de receber ou responder cartas endereçadas ao nome ou firma social.

8 - O uso de marca comum nas fazendas ou volumes.

9 - O uso de nome com a adição - e companhia.

A responsabilidade dos sócios ocultos é pessoal e solidária, como se fossem sócios ostensivos (artigo $\mathrm{n}^{\circ}$. 316).

\section{CARVALHO DE MENDONÇA ${ }^{163}$ também explica que o Código}

Comercial não enumerou as espécies de sociedades comerciais, ao contrário de códigos de outros países. O autor menciona que, como tipos clássicos de sociedades comerciais, tínhamos: (i) a sociedade em nome coletivo; (ii) a sociedade em comandita; e (iii) a sociedade anônima, que era a forma que prevalecia relativamente às mais vultosas empresas. $\mathrm{O}$ autor ensina, ainda, que:

Esses tipos de sociedades, definidos na lei e organizados sob regras fundamentais, não podem ser mutilados pela convenção das partes, como teremos ocasião de mostrar oportunamente. Eles servem para instruir imediatamente ao público sobre o critério legal a que são submetidas as sociedades e principalmente sobre a garantia que os sócios oferecem a terceiros.

Além dos tipos clássicos, CARVALHO DE MENDONÇA explica que o Código Comercial ainda contemplou: (i) a sociedade de capital e indústria (que, segundo ele, ao invés de ser tipo especial de sociedade comercial, é antes um dos modos da sua composição); e (ii) a sociedade em conta de participação, que não aparece nas relações para com terceiros. Faz-

\footnotetext{
163 MENDONÇA, José Xavier Carvalho de. Tratado de Direito Comercial Brasileiro. Rio de Janeiro: Livraria Freitas Bastos, $6^{\text {a }}$ edição (revista por Roberto Carvalho de Mendonça), 1963, vol. III, pp. 56 a 60.
} 
se referência também à sociedade cooperativa e a de crédito real. No entanto, percebe-se que a legislação brasileira ainda não previa a sociedade limitada. ${ }^{164}$

RACHEL SZTAJN, ao fazer referência ao projeto de código civil que deu origem ao Código Civil de 2002, explica o seguinte quanto ao regime anterior:

$\mathrm{Na}$ organização da disciplina societária o legislador pátrio não se utilizou dessa técnica - nem no Código Civil nem no Código Comercial. A par da caracterização dos tipos de sociedades comerciais - lembre-se que para as sociedades civis que não sejam cooperativas não há tipicidade fechada - o legislador dispõe de forma geral sobre a constituição, sobre a contribuição dos sócios para o exercício da atividade e sobre a partilha dos lucros; determinou a nulidade de sociedades em que todos os lucros ou prejuízos forem atribuídos a um ou alguns sócios; facultou a exclusão do sócio moroso na integralização de sua parte para a formação dos fundos sociais e, antes que a doutrina tivesse acordado sobre a teoria dos negócios plurilaterais, já estabelecera que o inadimplemento de um dos sócios não acarretaria a dissolução nem impediria a constituição de sociedade (CCom, arts. 287 e 293). ${ }^{165}$

Atualmente, enquanto o artigo $981^{166}$ do Código Civil de 2002 traz uma definição de contrato de sociedade, o artigo 983 exige que se adote um dos tipos societários previstos nos artigos 1.039 a 1.092 do código:

Art. 983. A sociedade empresária deve constituir-se segundo um dos tipos regulados nos arts. 1.039 a 1.092 ; a sociedade simples pode constituir-se de conformidade com um desses tipos, e, não o fazendo, subordina-se às normas que lhe são próprias.

Parágrafo único. Ressalvam-se as disposições concernentes à sociedade em conta de participação e à cooperativa, bem como as constantes de leis especiais que, para o exercício de certas atividades, imponham a constituição da sociedade segundo determinado tipo.

\footnotetext{
${ }^{164} \mathrm{O}$ autor acrescenta, após explicar que as sociedades limitadas são de origem inglesa e que em 1866 procurou-se criar no Brasil essas sociedades e sobre o projeto foi ouvido o Conselho de Estado (Seção de Justiça) que, em parecer daquele ano opinou por sua rejeição e que o imperador conformou-se com o parecer pela Resolução de 24 de abril de 1867: a admissão dessas sociedades romperia a tradição, perturbaria o nosso sistema e não traria vantagens mais positivas além das que oferecem as sociedades anônimas e comanditárias.

165 SZTAJN, Rachel. Contrato de Sociedade e Formas Societárias. São Paulo: Saraiva, 1989, Introdução, p. 146.

166 Art. 981. Celebram contrato de sociedade as pessoas que reciprocamente se obrigam a contribuir, com bens ou serviços, para o exercício de atividade econômica e a partilha, entre si, dos resultados.

Parágrafo único. A atividade pode restringir-se à realização de um ou mais negócios determinados.
} 
Nos termos desse artigo, "a regra quanto à eleição de um dos nove tipos é norma cogente, não admite interpretação". Assim, toda e qualquer sociedade empresária deverá ser organizada de acordo com uma das estruturas organizacionais previstas. ${ }^{167}$

Quanto à segunda parte do artigo, RACHEL SZTAJN explica que ela repete a regra do art. 1.364 do Código Civil de 1916 e é dispositiva ou supletiva e se aplica às sociedades não empresárias.

O artigo 983 é alvo de críticas por diversos autores brasileiros. Dentre eles, RACHEL SZTAJN repreende: “o artigo representa uma das mais extraordinárias intromissões do legislador e injustificada restrição ao exercício da autonomia privada encontradas neste Código Civil." ${ }^{\text {"68 }}$ Para ela, "limitar o âmbito de exercício da autonomia privada quando as pessoas celebram contrato de sociedade, negócio fundado na cooperação, no mínimo contradiz a principiologia do Código no que concerne à solidariedade, à cooperação."

\subsection{Adoção de cláusulas atípicas}

Tendo sido concluído que a tipicidade societária no direito brasileiro constitui um sistema taxativo, faz-se importante comentar brevemente sobre a possibilidade de se utilizar cláusulas atípicas no âmbito do tipo societário eleito.

Fazer uso de uma cláusula atípica não significa a escolha por uma sociedade atípica e, portanto, não descaracteriza a tipicidade societária.

Ao tratar da diferença entre atipicidade de sociedade e atipicidade de cláusulas, RACHEL SZTAJN explica:

O tipo legal constitui a previsão legislativa particular de um fato - típico disciplinado por normas específicas. Portanto, a distinção entre atipicidade de

${ }^{167}$ DA FONSECA, Priscila M. P. Corrêa; SZTAJN, Rachel. Código Civil Comentado. Direito da Empresa. Coordenação de Álvaro Villaça Azevedo. São Paulo: Atlas, 2008, vol. XI, p. 147.

${ }^{168}$ DA FONSECA, Priscila M. P. Corrêa; SZTAJN, Rachel. Código Civil Comentado. Direito da Empresa. Coordenação de Álvaro Villaça Azevedo. São Paulo: Atlas, 2008, vol. XI, p. 145. 
sociedade e atipicidade de cláusulas está em que estas não excluem, ao contrário, pressupõem o reconhecimento do tipo. As cláusulas atípicas são admitidas, tanto no ato de constituição das sociedades quanto em modificações posteriores, dentro de certos limites, nos vários ordenamentos. ${ }^{169}$

A autora também explica que a adoção de cláusulas atípicas não tem tanta importância, porque não chega a modificar as relações societárias externas, ou seja, as obrigações em relações a terceiros:

A atipicidade de cláusulas contratuais é frequente nos contratos de sociedade, especialmente se referida às relações societárias internas. Essa atipicidade não tem grande importância porque não chega a modificar as relações societárias externas, isto é, as obrigações e responsabilidades dos sócios em relação a terceiros. Se a cláusula atípica vier a ser considerada nula, desde que não seja condição imposta para a realização do negócio, aplica-se a regra utile per inutile non vitiatur, e a sociedade será regida, conforme o tipo adotado, pelas regras aplicáveis. ${ }^{170}$

Nada impede, portanto, que uma parte recorra a uma cláusula atípica, ou seja, uma disposição diferente das previstas em lei, para melhor adequar o contrato da sociedade a seus interesses. Importante questionar, no entanto, qual é o limite do conteúdo dessas cláusulas atípicas.

Para responder a essa questão, recorre-se a HAROLDO $\operatorname{VERÇOSA}^{171}$, que explica que o limite, tanto da utilização de cláusulas atípicas quanto das sociedades atípicas, é a observação das normas cogentes ou imperativas existentes no ordenamento jurídico:

O limite legalmente estabelecido para a atuação criativa dos sócios em relação a sociedades atípicas ou cláusulas atípicas de sociedades típicas está em que são fulminadas de nulidade aquelas que afrontarem as normas cogentes, porque não se admite, neste caso, a atuação da liberdade das convenções.

Na mesma linha, CARVALHO DE MENDONÇA ensina que é preciso observar as disposições proibitivas ou imperativas da lei. $\mathrm{O}$ autor faz referência ao exemplo das sociedades anônimas:

\footnotetext{
${ }^{169}$ SZTAJN, Rachel. Contrato de Sociedade e Formas Societárias. São Paulo: Saraiva, 1989, p. 163.

${ }^{170}$ SZTAJN, Rachel. Contrato de Sociedade e Formas Societárias. São Paulo: Saraiva, 1989, p. 163.

171 VERÇOSA, Haroldo Malheiros Duclerc. Curso de Direito Comercial. Teoria Geral das Sociedades -As Sociedades em Espécie do Código Civil. São Paulo: Malheiros, 2010, $2^{a}$ edição, pp. 80-82.
} 
Aos interessados não é permitido ajustar cláusulas que se oponham às disposições proibitivas ou imperativas da lei. Nas sociedades anônimas, numerosas são essas disposições, que constituem a sua regulamentação. Nas outras formas de sociedade é maior a liberdade dos contratantes. ${ }^{172}$

O próprio Código Civil de 2002, em seu artigo 166, VI, prevê que "o negócio jurídico será nulo quando tiver por objetivo fraudar lei imperativa". Essa hipótese se refere a situações de fraude à lei, que atentem contra disposições de ordem pública ${ }^{173}$.

A melhor interpretação, no entanto, é a de que a nulidade de determinada cláusula inserida no contrato da sociedade não deve ser arguida como capaz de tornar a sociedade nula como um todo. É o que entende HAROLDO VERÇOSA:

\begin{abstract}
Uma vez reconhecidas como nulas certas cláusulas de contratos sociais em concreto, não se pode levar a extensão da nulidade para a sociedade como um todo, porque esta terá efetivamente existido ao longo de um determinado período de tempo e relações jurídicas internas e externas foram criadas, com efeitos os mais diversos. Neste caso, o operador do Direito estará diante de uma sociedade irregular (que não se confunde com a antiga sociedade irregular ou de fato, ou com a sociedade em comum do $\mathrm{NCC}$ ), cujo tratamento jurídico será o da sociedade típica que veio a ser ilegalmente superada, com as consequências jurídicas correspondentes - o que costuma acontecer frequentemente pela aplicação de responsabilidade solidária e ilimitada entre os sócios e o patrimônio social comum diante de terceiros. ${ }^{174}$
\end{abstract}

É claro que tal afirmação precisa ser analisada na circunstância concreta e, portanto, admite exceções.

Para entender melhor a questão das cláusulas atípicas, podemos separar as regras que regem os tipos societários em (i) normas tipificadoras cogentes, ou seja, aquelas que são fundamentais para a caracterização de

\footnotetext{
172 MENDONÇA, José Xavier Carvalho de. Tratado de Direito Comercial Brasileiro. Rio de Janeiro: Livraria Freitas Bastos, $6^{a}$ edição (revista por Roberto Carvalho de Mendonça), 1963, vol. III, p. 10.

${ }_{173}$ TEPEDINO, Gustavo; BARBOZA, Heloisa Helena; DE MORAES, Maria Celina Bodin. Código Civil interpretado conforme a Constituição da República. Rio de Janeiro: Renovar, 2006, vol. II, p. 315.

${ }^{174}$ VERÇOSA, Haroldo Malheiros Duclerc. Curso de Direito Comercial. Teoria Geral das Sociedades -As Sociedades em Espécie do Código Civil. São Paulo: Malheiros, 2010, 2ª edição, pp. 80-82.
} 
um tipo e, portanto, de observação obrigatória caso por ele se opte; e (ii) normas tipificadoras dispositivas.

Feita essa classificação, recorre-se ao que VERÇOSA dispõe, ao tratar das normas tipificadoras dispositivas: "na legislação societária há normas que podem ser substituídas por outros esquemas contratuais acordados pelos sócios, que incluirão cláusulas atípicas em sociedades típicas.” Nesse caso, “o resultado será o surgimento de esquemas societários diversos daqueles originalmente postos pelo legislador, desde que características básicas obrigatórias não sejam afastadas pelo contrato social ou pelo estatuto".

Assim, nas circunstâncias concretas, as partes podem derrogar as normas tipificadoras dispositivas e inserir no contrato de sociedade cláusulas atípicas, sem que isso necessariamente acarrete na descaracterização do tipo societário eleito. RACHEL SZTAJN confirma esse entendimento:

Sabendo que os tipos normativos usualmente resultam de tipos sociais de negócios, de eventuais modificações da conjuntura socioeconômica, é usual recorrer-se às cláusulas atípicas insertas em contratos típicos para explicar as mutações tipológicas encontradas na prática.

Daí se chega à definição das regras cogentes, que não podem ser modificadas pelas partes porque se destinam a regular hipóteses típicas de conflito de interesses cuja solução fica afastada do poder dos particulares. As regras dispositivas que também são tipificadoras, ao revés, podem ser afastadas pelas partes e só atuam na falta de expressa disposição destas ao fato em concreto. ${ }^{175}$

Portanto, o limite do uso de cláusulas atípicas em um contrato de sociedade, para que não haja descaracterização do tipo, é justamente a observação das normas tipificadoras cogentes (que não se confundem com as normas cogentes do ordenamento jurídico). Eventual uso de cláusula atípica que viole essas normas terá como consequência a transformação da

${ }^{175}$ SZTAJN, Rachel. Contrato de Sociedade e Formas Societárias. São Paulo: Saraiva, 1989, p. 57. 
sociedade típica em atípica. Já a cláusula atípica que dispuser de normas tipificadoras dispositivas não terá o mesmo efeito.

Utilizando-se de um exemplo de norma tipificadora cogente, RACHEL SZTAJN dispõe que: "são inderrogáveis as normas referentes ao regime de responsabilidade fixadas para o tipo adotado, de um lado por representarem tutela de credores e, de outro, por serem estipuladas em benefício dos sócios". ${ }^{176}$ HAROLDO VERÇOSA também compartilha desse entendimento ${ }^{177}$.

\subsection{Sociedades atípicas?}

Se, por um lado, a questão da adoção de cláusulas atípicas não gera tanta divergência na doutrina, quando se fala sobre a possibilidade de constituição de sociedades atípicas, não se pode dizer o mesmo.

O que são, afinal, sociedades atípicas?

$\mathrm{Na}$ definição de RACHEL SZTAJN, são aquelas que "fogem a qualquer dos tipos legais, sendo resultado da autonomia privada, produto do poder dos particulares de, livremente, determinarem o conteúdo dos contratos, conforme a competência dispositiva que lhes é deferida, competência distinta do tratamento jurídico e da esfera de efeitos que dependem da competência normativa do ordenamento positivo". ${ }^{178}$

As sociedades atípicas, segundo a autora, podem ser de dois tipos: aditivas (que acrescem novos elementos aos tipos legais) e substitutivas (que modificam elementos tipificadores fixados em normas dispositivas,

\footnotetext{
${ }^{176}$ SZTAJN, Rachel. Contrato de Sociedade e Formas Societárias. São Paulo: Saraiva, 1989, p. 74.

177 VERÇOSA, Haroldo Malheiros Duclerc. Curso de Direito Comercial. Teoria Geral das Sociedades -As Sociedades em Espécie do Código Civil. São Paulo: Malheiros, 2010, $2^{\text {a }}$ edição, p. 81.

${ }^{178}$ SZTAJN, Rachel. Contrato de Sociedade e Formas Societárias. São Paulo: Saraiva, 1989, p. 163.
} 
excluindo ou acrescentando elementos que a lei não considere essenciais para a caracterização do tipo). ${ }^{179}$

A classificação utilizada pela autora não parece, no entanto, tratar de sociedades atípicas, afinal, conforme exposto no item anterior, nada impede que novos elementos sejam acrescidos aos tipos legais ou que elementos tipificadores contidos em normas de caráter dispositivo sejam modificados. Desde que, é claro, as normas tipificadoras cogentes não sejam atingidas.

No âmbito do direito societário anterior, as sociedades atípicas eram admitidas?

Ainda baseada no sistema jurídico anterior ao Código Civil de 2002, RACHEL SZTAJN, faz menção à possibilidade de se fazer uso de sociedades atípicas em diversos trechos de sua obra clássica sobre o tema:

Aceita-se que o sistema se compõe de tipos (e subtipos) que servirão de limites à autonomia privada, impedindo a criação de sociedades atípicas?

A possibilidade de moldar, em algum sentido, o conteúdo do contrato leva a admitir a existência de manifestação de autonomia privada e, dessa forma, a criação de sociedades atípicas é de ser tomada como forte resultado dessa mesma autonomia. ${ }^{180}$

$* * *$

Como, porém, nem todos os elementos tipificadores devem estar presentes em cada um dos contratos concretamente considerados, o procedimento em regra utilizado, da subsunção de um contrato determinado à estrutura do tipo, poderá não ter como resposta sim ou não, mas deverá ser respondido mais ou menos.

Nesse plano do mais ou menos não se pode estar diante de uma tipicificação fechada. ${ }^{181}$

$* * *$

Pergunta-se então se o sistema da lei brasileira possibilita a criação de estruturas organizacionais diversas das regulamentadas nos vários textos do Código Comercial e legislação extravagante.

(...)

179 SZTAJN, Rachel. Contrato de Sociedade e Formas Societárias. São Paulo: Saraiva, 1989, p. 163.

180 SZTAJN, Rachel. Contrato de Sociedade e Formas Societárias. São Paulo: Saraiva, 1989, p. 57.

${ }^{181}$ SZTAJN, Rachel. Contrato de Sociedade e Formas Societárias. São Paulo: Saraiva, 1989, p. 54. 
Ora, no direito brasileiro não há nenhuma disposição a respeito de um tipo básico de sociedade que serviria como estrutura associativa nuclear para os demais tipos.

(...)

A organização da matéria societária, tal como a encontramos no Código de Comércio, em que os tipos societários estão apresentados em blocos de regras gerais aplicáveis a todas as formas ali reguladas, não está a indicar a enumeração taxativa e sim um elenco exemplificativo, para os quais a diferente organização corresponde a uma designação, a uma denominação e, portanto, a escolha de um dos tipos do elenco apresentado na lei não parece, aprioristicamente, excluir a possibilidade de as partes estipularem outras regras e, desta forma, constituir tipo de sociedade distinto, ou seja, uma sociedade atípica. ${ }^{182}$

E no direito vigente, é possível valer-se de sociedades atípicas?

É de se notar que o Código Civil de 2002 alterou o regramento da matéria. Assim, ainda que se possa utilizar dos fundamentos anteriores para defender a possibilidade de sociedades atípicas, não se pode afirmar que essa posição não enfrentaria obstáculos.

Ao mencionar que o direito societário brasileiro aplica o princípio da tipicidade fechada ou de origem legal, JULIANA KRUEGER PELA entende serem vedadas as sociedades atípicas:

Segundo esse raciocínio, caso os agentes econômicos pretendam atuar cooperativamente para a consecução de um objetivo comum e intentem, para tanto, constituir sociedade, devem necessariamente valer-se de um dos tipos previstos na ordem jurídica. Consequentemente, ser-lhes-á vedado, no exercício da autonomia privada, criar estruturas societárias atípicas. ${ }^{183}$

No mesmo sentido, entende RACHEL SZTAJN em seus comentários, já na vigência do direito atual, ao artigo 983 do Código Civil de 2002:

Ao limitar a escolha e, portanto, a criação de tipos de estrutura organizacional pelos agentes econômicos no desenho das relações internas nas sociedades empresárias, impede a criação de sociedades atípicas. A violência com que o legislador investe contra a autonomia privada pode ser encarada como contrária

${ }^{182}$ SZTAJN, Rachel. Contrato de Sociedade e Formas Societárias. São Paulo: Saraiva, 1989, p. 148.

183 PELA, Juliana Krueger. As Golden Shares no Direito Brasileiro. São Paulo: Quartier Latin, 2012, p. 108. 
ao teor do art. 170 da Constituição da República, que visa a garantir a livre iniciativa de forma ampla. ${ }^{184}$

A autora não concorda com a forma que o legislador utilizou para tratar da questão, mas reconhece que, uma vez elencados os tipos aos quais os agentes devem recorrer, a criação de sociedades atípicas torna-se inviável. Em sua opinião, essa disposição representa uma violação à livre iniciativa.

Há quem entenda, no entanto, que o direito brasileiro admite formas atípicas de sociedade. É o que defende MARCELO FÉRES, ao dispor que, na ausência de vedação expressa, elas seriam permitidas:

Por fim, em sede de arremate, pode-se dizer que, apesar das divergências doutrinárias, não existindo vedação expressa numa ordem jurídica, não se pode negar à autonomia das partes a possibilidade de formatação de negócios societários atípicos. É claro, também, que desde negócios, não se podem derivar pessoas jurídicas. Entretanto, são válidos e eficazes entre as partes, bem como perante terceiros, respeitada, conforme melhor se demonstrará mais adiante, a ordem pública societária. Enfim, tampouco os efeitos das sociedades atípicas são os mesmos daquelas típicas. ${ }^{185}$

A saída encontrada pelo autor é fazer uso do argumento de que, em que pese a criação de uma sociedade atípica seja possível, a obtenção de personalidade jurídica não o é:

Portanto, note-se, o art. 983 do Código Civil refere-se, preponderantemente, ao exercício da atividade empresarial sob a forma de sociedade empresária, pessoa jurídica regularmente constituída. Não traz qualquer sanção imediata à opção por sociedades atípicas. Apenas evidencia, no sistema como um todo, que as sociedades atípicas não são personificáveis, tampouco ingressam no campo das atividades econômicas formais e regulares. Nada obsta, porém, que existam e sejam válidas.

(...)

Desse modo, o negócio societário pode assumir qualquer forma não proibida pela ordem jurídica. É lógico que a assunção de forma não prevista pelo ordenamento (art. 983 do Código Civil) dificulta a vida da sociedade, mas não lhe subtrai a validade. Como mencionado, insista-se: não se trata de sociedade personificável,

${ }^{184}$ DA FONSECA, Priscila M. P. Corrêa; SZTAJN, Rachel. Código Civil Comentado. Direito da Empresa. Coordenação de Álvaro Villaça Azevedo. São Paulo: Atlas, 2008, vol. XI, p. 146.

${ }^{185}$ FÉRES, Marcelo Andrade. Sociedade em Comum - Disciplina Jurídica e Institutos Afins. São Paulo: Editora Saraiva, 2011, p. 66. 
mas apenas e tão somente de negócio societário válido e com plenos efeitos entre as partes. ${ }^{186}$

Da leitura do artigo 983, até cabe argumentar que é possível a criação de uma sociedade atípica. No entanto, não se pode negar que a possibilidade de obtenção de personalidade jurídica é exclusiva dos tipos elencados pela lei.

Outro autor que defende essa posição, ao fazer referência ao modelo italiano, que é similar ao brasileiro, é ISIDORO LA LUMIA. O autor italiano entende que os contratos atípicos são válidos e eficazes assim como os contratos típicos. A diferença, no entanto, é que os contratos típicos dão origem a um novo sujeito de direito, enquanto os contratos atípicos determinam mero estado de comunhão entre as partes, o que é diferente de qualquer conceito de personalidade jurídica ${ }^{187}$.

SYLVIO MARCONDES assim diferencia a sociedade da personificação:

Ora, a sociedade, acordo de vontades apto a constitui direitos subjetivos, é
negócio jurídico, a produzir efeitos imediatos, de caráter societário e
independentes de que ela adquira, ou não, personalidade jurídica. A
personificação, fenômeno posterior, do qual a existência da sociedade é
pressuposto, constitui a fonte geratriz de um novo sujeito de direito, capacitado a
ser titular do patrimônio especial, que, previamente composto pelas partes
separadas dos patrimônios individuais dos sócios, se desliga da titularidade
destes, para transformar-se em patrimônio autônomo, objeto de nova
titularidade. ${ }^{188}$

Como se sabe, no regime jurídico vigente, a personificação é adquirida com o registro da sociedade. Vale notar que essa afirmação é matéria de discussão, pois há quem entenda que mesmo antes do registro, já há certa personalidade jurídica, ainda que limitada. É o caso de CALIXTO SALOMÃO FILHO:

\footnotetext{
${ }^{186}$ FÉRES, Marcelo Andrade. Sociedade em Comum - Disciplina Jurídica e Institutos Afins. São Paulo: Editora Saraiva, 2011, p. 68.

187 LA LUMIA, Isidoro. La “Atipicità" nelle Società Commerciali. In: Rivista del Diritto Commerciale, vol. XXXVI, parte I, 1938, p. 227.

${ }^{188}$ MARCONDES, Sylvio. Problemas de Direito Mercantil. São Paulo: Max Limonad, 1970, pp. 144 e 145 .
} 
A concepção mais moderna da personalidade jurídica não mais defende uma visão unitária do fenômeno, mas sim uma visão pluralista, que identifica na personalidade jurídica um centro de imputação de direitos e deveres que pode ser moldada segundo a importância de cada norma a ser aplicada. Assim, a existência de alguma, ainda que limitada, capacidade jurídica já é suficiente para caracterizar a existência de personalidade jurídica ainda que limitada a certos fins. A plena capacidade, e portanto, plena personalidade, só terá quando do registro $^{189}$.

No entanto, há quem sustente que nesse caso não se trataria de personalidade jurídica, mas sim de sujeitos de direito não personificados. Esse entendimento parece mais coerente com o que dispõe o artigo $45^{190}$ combinado com o artigo $985^{191}$ do Código Civil de $2002^{192}$.

Em decorrência, a impossibilidade de registro e a consequente falta de personalidade jurídica trariam diversos prejuízos e dificultariam a vida da sociedade, por se mostrar a personalidade jurídica imprescindível para que a sociedade possa se valer das vantagens, de diversas naturezas, concedidas pela lei.

Se, conforme já exposto ao longo deste trabalho, os elementos mais importantes da sociedade são justamente, no âmbito interno, a possibilidade de limitação da responsabilidade, a diminuição significante de custos e a existência de personalidade distinta da dos sócios e, no âmbito externo, a proteção dos interesses de terceiros, qual seria, então, a utilidade da sociedade atípica sem personalidade jurídica?

\footnotetext{
${ }^{189}$ SALOMÃO FILHO, Calixto. A Sociedade Unipessoal. São Paulo: Malheiros, 1995, pp.95 e 96. Apud FRANÇA, Erasmo Valladão Azevedo e Novaes. Ensaio Sobre a Sociedade em Comum. Tese para a obtenção do título de Livre-docente em Direito Comercial pela Faculdade de Direito da Universidade de São Paulo, 2011.

${ }^{190}$ Art. 45. Começa a existência legal das pessoas jurídicas de direito privado com a inscrição do ato constitutivo no respectivo registro, precedida, quando necessário, de autorização ou aprovação do Poder Executivo, averbando-se no registro todas as alterações por que passar o ato constitutivo.

${ }^{191}$ Art. 985. A sociedade adquire personalidade jurídica com a inscrição, no registro próprio e na forma da lei, dos seus atos constitutivos (arts. 45 e 1.150).

${ }^{192}$ FRANÇA, Erasmo Valladão Azevedo e Novaes. Ensaio Sobre a Sociedade em Comum. Tese para a obtenção do título de Livre-docente em Direito Comercial pela Faculdade de Direito da Universidade de São Paulo, 2011, pp. 144 e 145.
} 


\subsubsection{Um paralelo entre a sociedade atípica e a sociedade em comum}

ERASMO VALLADÃO, em sua recente tese de livre-docência sobre o assunto, explica que a sociedade em comum se configura em três hipóteses: (i) quando for constituída e exercer sua atividade sem prova escrita (correspondente à antiga sociedade de fato); (ii) quando for constituída e exercer sua atividade com prova escrita, mas sem inscrição no registro próprio, ou antes dele (correspondente à antiga sociedade irregular); e (iii) quando for constituída mas seu registro for cancelado e a sociedade continuar o exercício da sua atividade ${ }^{193}$.

No Código Civil de 2002, a sociedade em comum está prevista nos artigos 986 a $990^{194}$.

A ponderação que se visa fazer aqui é em que medida as sociedades atípicas e as sociedades em comum se aproximam, já que ambas são marcadas pela falta de personalidade jurídica.

Nas palavras de ERASMO VALLADÃO, a questão que se coloca é se a sociedade em comum seria também um tipo societário, já que não está referida no art. 983, ou se haveria possibilidade de criação de formas societárias atípicas ${ }^{195}$.

MARCELO FÉRES, por exemplo, sustenta que o numerus clausus das sociedades empresárias só se aplicaria àquelas que adquirem

\footnotetext{
${ }^{193}$ FRANÇA, Erasmo Valladão Azevedo e Novaes. Ensaio Sobre a Sociedade em Comum. Tese para a obtenção do título de Livre-docente em Direito Comercial pela Faculdade de Direito da Universidade de São Paulo, 2011, pp. 116 e 117.

${ }^{194}$ Da Sociedade em Comum

Art. 986. Enquanto não inscritos os atos constitutivos, reger-se-á a sociedade, exceto por ações em organização, pelo disposto neste Capítulo, observadas, subsidiariamente e no que com ele forem compativeis, as normas da sociedade simples.

Art. 987. Os sócios, nas relações entre si ou com terceiros, somente por escrito podem provar a existência da sociedade, mas os terceiros podem prová-la de qualquer modo.

Art. 988. Os bens e dívidas sociais constituem patrimônio especial, do qual os sócios são titulares em comum.

Art. 989. Os bens sociais respondem pelos atos de gestão praticados por qualquer dos sócios, salvo pacto expresso limitativo de poderes, que somente terá eficácia contra o terceiro que o conheça ou deva conhecer.

Art. 990. Todos os sócios respondem solidária e ilimitadamente pelas obrigações sociais, excluído do benefício de ordem, previsto no art. 1.024, aquele que contratou pela sociedade.

195 FRANÇA, Erasmo Valladão Azevedo e Novaes. Ensaio Sobre a Sociedade em Comum. Tese para a obtenção do título de Livre-docente em Direito Comercial pela Faculdade de Direito da Universidade de São Paulo, 2011, p. 129.
} 
personalidade jurídica ${ }^{196}$. Logo, uma sociedade em comum poderia ser atípica.

ERASMO VALLADÃO, após fazer uma breve exposição sobre o que se entende por tipo societário, explica que alguns (como TAVARES GUERREIRO, por exemplo), concluem que os tipos ou formas de sociedades acham-se estruturados em torno do elemento fundamental da responsabilidade dos sócios. Assim, ao seguir a posição de Ferri, o autor explica que a sociedade em comum não poderia ser considerada um tipo societário, pois a sua estrutura organizativa segue a da sociedade simples (ou de outras sociedades que esta pode adotar). ${ }^{197}$

Se, por um lado, as sociedades em comum não são atreladas a tipo societário específico, mas podem fazer uso de qualquer dos tipos societários previstos em lei (o que leva à conclusão de que não necessariamente elas adotariam a forma de sociedades atípicas), por outro, questiona-se se as sociedades atípicas serão sempre sociedades em comum.

Para responder a essa questão, vale recorrer ao trabalho de ERASMO VALLADÃO, que entende que o regime de responsabilidade previsto para as sociedades sem registro, ou seja, as sociedades em comum, deverá ser sempre observado, ainda que se admita a possibilidade de sociedades atípicas:

A uma conclusão, entretanto, pode-se seguramente chegar. Parece-nos irrecusável que o regime de responsabilidade previsto para a sociedade sem registro é cogente (até porque a sociedade sem registro pode ser empresária ou simples, como se verá). Dessa forma, ainda que se admita a possibilidade de sociedades atípicas, antes do registro, desse regime não se pode fugir, pelo

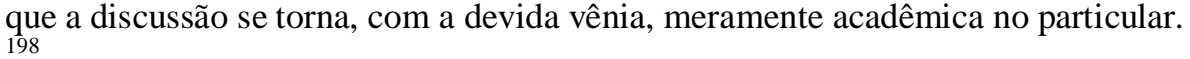

\footnotetext{
${ }^{196}$ FÉRES, Marcelo Andrade. Sociedade em Comum - Disciplina Jurídica e Institutos Afins. São Paulo: Editora Saraiva, 2011, p. 68.

${ }^{197}$ FRANÇA, Erasmo Valladão Azevedo e Novaes. Ensaio Sobre a Sociedade em Comum. Tese para a obtenção do título de Livre-docente em Direito Comercial pela Faculdade de Direito da Universidade de São Paulo, 2011, pp. 128 - 131.

${ }^{198}$ FRANÇA, Erasmo Valladão Azevedo e Novaes. Ensaio Sobre a Sociedade em Comum. Tese para a obtenção do título de Livre-docente em Direito Comercial pela Faculdade de Direito da Universidade de São Paulo, 2011, p. 131.
} 
Assim, não tendo registro, a sociedade se encaixa na definição do artigo 986 do Código Civil de 2002 e, consequentemente, as regras previstas naquele capítulo devem ser observadas.

Contudo, por ser essa questão puramente teórica, é extremamente difícil se chegar a respostas concretas sobre os inúmeros questionamentos que surgem sobre o assunto. Apesar de não ser o foco deste trabalho, os dois temas estão intrinsecamente relacionados e, mesmo que de forma breve, não se podia deixar de abordar aqui o paralelo com a sociedade em comum. 


\section{Conclusão}

Após todo o exposto, visa-se responder, primeiramente à seguinte questão: a adoção de um sistema típico fechado é a melhor alternativa?

Conforme se nota, um sistema típico fechado tem sua razão de ser e é importante para tutelar os interesses de terceiros e as relações internas das sociedades. No entanto, é preciso ponderar se esses fundamentos da tipicidade são mais importantes do que a vontade das partes no âmbito de uma relação jurídica.

Há de se reconhecer que a imputação de limites, na medida em que a lei dispõe que as partes devem optar por um dos tipos taxativamente descritos, caracteriza uma atenuação da aplicação do princípio autonomia da vontade das partes. Quanto mais empecilhos as pessoas encontram para montar seus negócios de forma livre, menor é o apetite do agente econômico pela assunção de riscos. O exercício da empresa, no entanto, é uma atividade econômica e, em consequência, possui riscos a ela inerentes $^{199}$.

Como explica RACHEL SZTAJN, há também uma questão de falta de coerência do artigo 983 do Código Civil com princípios ali previstos:

Limitar o âmbito de exercício da autonomia privada quando as pessoas celebram contrato de sociedade, negócio fundado na cooperação, no mínimo contradiz a principiologia do Código no que concerne à solidariedade, à cooperação. ${ }^{200}$

Além disso, dada a demonstração da importância da conjuntura socioeconômica, é de se questionar se a descrição de tipos em lei, de forma taxativa, é capaz de acompanhar a realidade e os interesses dos indivíduos, que estão constantemente em mutação. Como se sabe, a autonomia privada

\footnotetext{
${ }^{199}$ DA FONSECA, Priscila M. P. Corrêa; SZTAJN, Rachel. Código Civil Comentado. Direito da Empresa. Coordenação de Álvaro Villaça Azevedo. São Paulo: Atlas, 2008, vol. XI, p. 148.

200 DA FONSECA, Priscila M. P. Corrêa; SZTAJN, Rachel. Código Civil Comentado. Direito da Empresa. Coordenação de Álvaro Villaça Azevedo. São Paulo: Atlas, 2008, vol. XI, p. 146.
} 
ganha cada vez mais destaque na vida econômica atual, em virtude da velocidade com que negócios são ajustados entre particulares ${ }^{201}$.

Nesse sentido dispõe RACHEL SZTAJN:

Aceitar a tipicidade societária no sistema das sociedades comerciais deve ser resultado da análise das várias estruturas adotadas no exercício do comércio e da empresa, e das mutantes necessidades e interesses que devem ser permanentemente compatibilizados para que o exercício da empresa se faça em beneficio da comunidade. ${ }^{202}$

Outro ponto que merece destaque se refere ao fato de que, nas regras anteriores relacionadas ao direito societário, ou seja, previstas no Código Civil de 1916 e no Código Comercial, havia uma quantidade muito menor de normas consideradas cogentes o que, por si só, independentemente de como se dava o regime da tipicidade, conferia às partes mais autonomia.

Hoje, por outro lado, não se pode dizer o mesmo. As regras que regulam as sociedades no Brasil, além de disporem de muito mais detalhes referentes a cada tipo, tratam de determinados aspectos como sendo de observância obrigatória, que não eram imperativos na vigência da lei anterior.

Portanto, em um ordenamento como o nosso, em que os tipos societários são extremamente fechados, a adoção de um sistema tipicamente fechado pode não ser a melhor solução.

A tipicidade societária fechada exige que os tipos sejam mais abertos e flexíveis, compostos de mais normas tipificadoras dispositivas do que cogentes. Assim, os indivíduos teriam mais autonomia no âmbito dos próprios tipos eleitos e, talvez, a alegação de que a autonomia da vontade não se faz presente poderia ser afastada.

Além disso, embora seja importante que as pessoas possam dispor livremente sobre seus interesses, também é fundamental que aqueles que

${ }^{201}$ DA FONSECA, Priscila M. P. Corrêa; SZTAJN, Rachel. Código Civil Comentado. Direito da Empresa. Coordenação de Álvaro Villaça Azevedo. São Paulo: Atlas, 2008, vol. XI, p. 147.

202 SZTAJN, Rachel. Contrato de Sociedade e Formas Societárias. São Paulo: Saraiva, 1989, p. 58. 
venham a estabelecer uma relação com a sociedade possam nela ter confiança.

Assim, para predominar a liberdade das partes na seleção de regras relativas às sociedades das quais fazem parte, é preciso que sejam sempre observadas a ordem pública, a moral e a boa-fé. Nesse sentido, recorre-se novamente às palavras de RACHEL SZTJAN:

\begin{abstract}
Adequado seria facilitar aos agentes econômicos organizarem seus interesses como melhor lhes conviesse, respeitados, sempre, os interesses de terceiros, ordem pública, moral e bons costumes, estimulando-os a desenhar estruturas negociais que reduzissem conflitos entre eles que surgissem ao longo do tempo de existência da sociedade; facultados todos e quaisquer ajustes que promovessem, incentivassem, facilitassem a convivência das pessoas sem tolherlhes a liberdade de dispor, como melhor lhes convier, a respeito de seus interesses.
\end{abstract}

(...) A organização da atividade econômica deve ser livre, cuidando-se de impedir que sejam privilegiados os interesses dos sócios em detrimento de terceiros, em particular os credores da sociedade e a comunidade em que atue. ${ }^{203}$

Outro ponto que se visa responder é se é possível a criação de sociedades atípicas no Brasil.

Em regra, observando-se a letra da lei brasileira, a criação de uma sociedade atípica não seria possível. No entanto, há uma saída para essa alegação.

Conforme se extrai do artigo 983 do Código Civil de 2002, há a imposição de que a constituição de uma sociedade observe um dos tipos previstos, mas não há vedação expressa à utilização de um tipo diferente.

Assim, poderia alegar-se que a constituição de uma sociedade atípica é possível, apesar de a hipótese ser improvável. Isso se dá porque o ato constitutivo de uma sociedade que não respeita as descrições de tipos previstas na lei não é passível de registro e, portanto, não há meios para que a sociedade possa adquirir personalidade jurídica.

\footnotetext{
${ }^{203}$ DA FONSECA, Priscila M. P. Corrêa; SZTAJN, Rachel. Código Civil Comentado. Direito da Empresa. Coordenação de Álvaro Villaça Azevedo. São Paulo: Atlas, 2008, vol. XI, p. 146.
} 
A falta de personalidade jurídica, por sua vez, gera diversas implicações práticas, das quais se pode destacar, sem prejuízo de outras:

(i) o significativo aumento dos custos de transação;

(ii) as dificuldades encontradas na hora de se tratar de questões regulatórias e tributárias da sociedade;

(iii) a falta de limitação de responsabilidade dos sócios, que responderiam com seu patrimônio pessoal, caso necessário;

(iv) a ausência de separação patrimonial entre a sociedade e os respectivos sócios ${ }^{204}$;

(v) a insegurança de terceiros em contratar com a sociedade;

(vi) a falta de legitimidade ativa para requerer falência de seu devedor (artigo 97, VI e par. $1^{\circ}$ da Lei de Falência), bem como a falta de legitimidade ativa para requerer recuperação judicial ou extrajudicial (artigos 48, 51, V e 161 da Lei de Falência) ${ }^{205}$;

(vii) a impossibilidade de autenticar os livros na junta comercial (artigo 1.181, par. Único do Código Civil de 2002), faltando eficácia probatória a favor dos sócios (artigos 226 do Código Civil de 2002 e 379 do Código de Processo Civil);

(viii) a falta de proteção do nome (artigo 1.166 do Código Civil de 2002);

(ix) a impossibilidade de participação em licitações (artigo 28, III e IV da Lei 8.666/1993); e

(x) a impossibilidade de registro de marca (artigo 128 da Lei 9.279/1996).

\footnotetext{
${ }^{204}$ Faz-se uma ressalva quanto a este ponto no sentido de que, ao se entender que a sociedade atípica tem tratamento de sociedade em comum, o elemento da separação patrimonial estaria presente, conforme dispõe o artigo 988 do Código Civil de 2002 (art. 988. Os bens e dívidas sociais constituem patrimônio especial, do qual os sócios são titulares em comum).

${ }^{205}$ No que se refere aos itens (vi) a (x), vide FRANÇA, Erasmo Valladão Azevedo e Novaes. Ensaio Sobre a Sociedade em Comum. Tese para a obtenção do título de Livre-docente em Direito Comercial pela Faculdade de Direito da Universidade de São Paulo, 2011, pp. 138 e 139. Importante também mencionar que a maioria dessas disposições se refere, sobretudo, às sociedades empresárias, cuja atividade sem o registro é irregular.
} 
Nessa linha de pensamento, CAIO MÁRIO DA SILVA PEREIRA faz uma observação interessante ao dizer que, mesmo podendo optar por cláusulas atípicas, as partes, para se sentirem mais seguras, nunca as desprezam por completo:

A importância prática da classificação não pode ser negada. Quando os contratantes realizam um ajuste daqueles que são típicos, adotam implicitamente as normas legais que compõem a sua dogmática. É certo que tais regras são de natureza supletiva, e não imperativa, mas nem por isto de aplicação menos frequente, já que as partes, por mais casuístas que sejam no minudenciarem as cláusulas contratuais, nunca chegam a ponto de desprezarem as regras legislativas da figura típica. A celebração de um contrato atípico exige-lhes o cuidado de descerem a minúcias extremas, porque na sua disciplina legal falta a sua regulamentação específica. Na solução das controvérsias que surgirem, o julgador ou intérprete terá de invocar em suprimento do conteúdo das cláusulas próprias os princípios legais relativos ao contrato típico mais próximo, e isto nem sempre é fácil, porque a ocupação de zona grísea, entre mais de um, sugere às vezes aproximações várias, nenhuma das quais dotada de pura nitidez. $^{206}$.

Tendo em vista todo o exposto, conclui-se, portanto, que os ônus que enfrentaria uma sociedade atípica seriam muito maiores do que eventual vantagem que a liberdade de convencionar traria aos sócios.

Na teoria ela é possível, mas na prática é outra história.

Por fim, também é possível concluir que a sociedade atípica não registrada $^{207}$ poderá ser tratada como uma sociedade em comum, submetendo-se às regras que lhe são próprias.

\footnotetext{
${ }^{206}$ PEREIRA, Caio Mário da Silva. Instituições de Direito Civil. Rio de Janeiro: editora Forense, $15^{\mathrm{a}}$ edição, 2011, Vol. III, pp. 52 e 53.

${ }^{207}$ Parece óbvio que a sociedade atípica necessariamente não será registrável. No entanto, faz-se uma ressalva para eventual exceção que possa surgir. Pensa-se na hipótese de, por exemplo, a constituição de uma sociedade atípica vir a ser autorizada por norma específica.
} 


\section{Referências Bibliográficas}

AMARAL NETO, Francisco dos Santos. A Autonomia Privada como Princípio Fundamental da Ordem Jurídica - Perspectivas Estrutural e Funcional. In: Doutrinas Essenciais de Direito Civil, vol. 2, out/2010. Acesso pela Revista dos Tribunais Online em 19.09.2012.

ARMOUR, John; HANSMANN, Henry; e KRAAKMAN, Reinier. What is Corporate Law? In: The Anatomy of Corporate Law - A Comparative and Functional Approach. New York: Oxford University Press Inc., 2009, $322 \mathrm{p}$.

ASCARELLI, TUlliO. $O$ Desenvolvimento do Direito Comercial e o Significado da Unificação do Direito Privado. Tradução de Fábio Konder Comparato. In: Revista de Direito Mercantil Industrial, Econômico e Financeiro, Ano XXXVII vol. 114, 1999, pp. 237-252.

ASCARELLI, TULLIO. Problemas das Sociedades Anônimas e Direito Comparado. São Paulo: Saraiva, 1945, 593 p.

BALLANTINE, Henry Winthrop. Ballantine on Corporations. Chicago: Callaghan and Company, 1946, 992 p.

BEBCHUK, Lucian Arye. The Debate on Contractual Freedom in Corporate Law. In: Columbia Law Review n. 89, 1989, pp. 1395-1415.

CABRAL, Érico de Pina. A “Autonomia” no Direito Privado. Revista de Direito Privado, vol. 19, jul/2004. Acesso pela Revista dos Tribunais Online em 19.09.2012. 
CLARK, Robert. Contracts, Elites, and Traditions in the Making of Corporate Law. In: Columbia Law Review n. 89, 1989, pp. 1703-1747.

COASE, Ronald Harry. The firm, the Market, and the Law. Chicago: The University of Chicago Press, 1988, 217 p.

COASE, Ronald Harry. The Nature of the Firm. Economica, vol. 4, nº 16, 1937, publicação de Blackwell Publishing (The London School of Economics and Political Science) pp. 386-405.

COFFEE, John C. The Mandatory/Enabling Balance in Corporate Law: an Essay on the Judicial Role. In: Columbia Law Review n. 89, 1989, pp. $1618-1691$.

CORDEIRO, António Menezes. Direito Europeu das Sociedades. Coimbra: Almedina, 2005, 1123 p.

CORDEIRO, António Menezes. Manual de Direito das Sociedades. Coimbra: Almedina, 2007, vol. II, 926 p.

CORRADO, Diego. Il Diritto dele Società tra Autonomia dei Privati e Intervento del Legislatore. In: Revista de Direito Mercantil Industrial, Econômico e Financeiro, Ano XLII, vol. 131, 2003, pp. 21-43.

DA FONSECA, Priscila M. P. Corrêa; SZTAJN, Rachel. Código Civil Comentado. Direito da Empresa. Coordenação de Álvaro Villaça Azevedo. São Paulo: Atlas, 2008, vol. XI 903 p.

DAVIES, Paul L. Gower and Davies' Principles of Modern Company law. England: Thomson Reuters Limited, 2008, 1258 p. 
EASTERBROOK, Frank H.; FISCHEL, Daniel R. The Corporate Contract. In: Columbia Law Review n. 89, 1989, pp. 1416-1448.

EASTERBROOK, Frank; e FISCHEL, Daniel. The Economic Structure of Corporate Law. London: Harvard University Press, 1948, 370 p.

EISENBERG, Melvin. The Structure of Corporation Law. In: Columbia Law Review n. 89, 1989, pp. 1461 - 1525.

FRANÇA, Erasmo Valladão Azevedo e Novaes. Conflito de Interesses nas Assembleias de S.A. São Paulo: Malheiros, 1993, 109 p.

FRANÇA, Erasmo Valladão Azevedo e Novaes. Ensaio Sobre a Sociedade em Comum. Tese para a obtenção do título de Livre-docente em Direito Comercial pela Faculdade de Direito da Universidade de São Paulo, 2011, $188 \mathrm{p}$.

FRANCO, VERA HELENA DE MELLO. As Sociedades de Pessoas na Atualidade. Uma Visão Comparativa Crítica. In: Revista de Direito Mercantil Industrial, Econômico e Financeiro, Ano L, vol. 157, 2011, pp. 93-114.

FÉRES, Marcelo Andrade. Sociedade em Comum - Disciplina Jurídica e Institutos Afins. São Paulo: Editora Saraiva, 2011, 238 p.

GANDARA, Luis Fernandez de la. La Atipicidad en Derecho de Sociedades. Zaragoza: Pórtico, [s.d.], 496 p. 
GORDON, Jeffrey N. The Mandatory Structure of Corporate Law. In: Columbia Law Review n. 89, 1989, pp. 1549-1598.

GUERREIRO, José Alexandre Tavares. O Estado e a Economia dos Contratos Privados. In: Revista de Direito Mercantil Industrial, Econômico e Financeiro, vol. 31, Ano XVII, 1978, pp. 77-88.

HANSMANN, Henry; KRAAKMAN, Reinier. The Essential Role of Organizational Law. In: The Yale Law Journal, vol. 110, nº 3, 2000, pp. 387-440.

HART, Oliver. An Economist Perspective on the Theory of the Firm. In: Columbia Law Review, vol. 89, 1989, pp. 1757-1774.

KORNHAUSER, Lewis A. The Nexus of Contract Approach to Corporations: A Comment on Easterbrook and Fischel. In: Columbia Law Review n. 89, 1989, pp. 1449-1460.

LA LUMIA, ISIDORO. La "Atipicità" nelle Società Commerciali. In: Rivista del Diritto Commerciale, vol. XXXVI, parte I, 1938, pp. 217-235.

LAMY FILHO, Alfredo e PEDREIRA, José Luiz Bulhões (coordenadores). Direito das Companhias. Rio de Janeiro: Editora Forense, 2009, vol. I, 1288 p.

LAMY FILHO, Alfredo; PEDREIRA, José Luiz Bulhões. A Lei das S.A. $3^{\text {a }}$ edição. Rio de Janeiro: Renovar, 1997, vol. I, 508 p. 
LARENZ, Karl. Methodenlehre der Rechtswissenschaft (Metodologia da Ciência do Direito), $6^{\text {a }}$ edição. Tradução de José Lamego, $3^{a}$ edição, Lisboa: Fundação Calouste Gulbenkian, 1997, 727 p.

LÔBO, Paulo Luiz Netto. Autonomia da Vontade (no Direito Contratual). In: TORRES, Ricardo Lobo; KATAOKA, Eduardo Takemi; GALDINO, Flavio, organizadores; TORRES, Silvia Faber Torres, supervisora. Dicionário de Princípios Jurídicos. Rio de Janeiro: Elsevier, 2011, 1420 p.

MARCONDES, Sylvio. Problemas de Direito Mercantil. São Paulo: Max Limonad, 1970, 434 p.

MARINO, Daniela Ramos Marques. O Status Socii. In: FRANÇA, Erasmo Valladão Azevedo e Novaes, Direito Societário Contemporâneo I. São Paulo: Quartier Latin do Brasil, 2009, 632 p.

MENDONÇA, José Xavier Carvalho de. Tratado de Direito Comercial Brasileiro. $6^{\text {a }}$ edição (revista por Roberto Carvalho de Mendonça). Rio de Janeiro: Livraria Freitas Bastos, 1963, vol. III, 470 p.

MIRANDA, Pontes de. Tratado de Direito Privado. Parte Geral. $3^{\text {a }}$ edição. Rio de Janeiro: Editor Borsoi, 1970, Tomo III, 511 p.

MIRANDA, Pontes de. Tratado de Direito Privado. Parte Geral. $3^{\text {a }}$ edição. São Paulo: Editora Revista dos Tribunais, 1984, Tomo XXXVIII, 447 p.

MIRANDA, Pontes de. Tratado de Direito Privado. Parte Geral. $3^{\text {a }}$ edição. São Paulo: Editora Revista dos Tribunais, 1984, Tomo XLIX, 591 p. 
OLIVEIRA, José Lamartine Corrêa. A Dupla crise da Pessoa Jurídica. São Paulo: Saraiva, 1979, 694 p.

PELA, Juliana Krueger. As Golden Shares no Direito Brasileiro. São Paulo: Quartier Latin, 2012, 227 p.

PEREIRA, Caio Mário da Silva. Instituições de Direito Civil. 15a edição. Rio de Janeiro: editora Forense, 2011, Vol. III, 568 p.

RAJAN, Raghuram G.; ZINGALES, Luigi. Power in a Theory of the Firm. In: The Quarterly Journal of Economics, vol. 113, no 2, 1998, p. 387432.

REQUIÃO, Rubens. Curso de Direito Comercial. 28a. edição. São Paulo: Saraiva, 2009, vol. I, p. 433.

ROBERT, Bruno. Dividendo Mínimo Obrigatório nas Sociedades por Ações Brasileiras. Apuração, Declaração e Pagamento. São Paulo: Quartier Latin, 2011, 197 p.

SALOMÃO FILHO, Calixto. "Societas" com Relevância Externa e Personalidade Jurídica. In: Revista de Direito Mercantil Industrial, Econômico e Financeiro, vol. 81, Ano XXX, 1991, pp. 66-78.

SIMIONATO, Frederico A. Monte. Tratado de Direito Societário. Rio de Janeiro: Forense, 2009, vol. I, 798 p.

SPADA, Paolo. La TIpicità delle Società. Padova: CEDAM, 1974, 482 p. 
STJ, REsp 972.436 - BA (2007/0179867-7), Rel. Ministra Nancy Andrighi, Brasília, julgado em 17 de março de 2009.

SZTAJN, Rachel. Contrato de Sociedade e Formas Societárias. São Paulo: Saraiva, 1989, $187 \mathrm{p}$.

SZTAJN, Rachel. Teoria Jurídica da Empresa: Atividade Empresária e Mercados. São Paulo: Atlas, 2004, 225 p.

TEPEDINO, GUSTAVO. Multipropriedade Imobiliária. São Paulo: Saraiva, 1993, $137 \mathrm{p}$.

TEPEDINO, Gustavo; BARBOZA, Heloisa Helena; DE MORAES, Maria Celina Bodin. Código Civil interpretado conforme a Constituição da República. Rio de Janeiro: Renovar, 2006, vol. II, 909 p.

VERÇOSA, Haroldo Malheiros Duclerc. Curso de Direito Comercial. Teoria Geral das Sociedades - As Sociedades em Espécie do Código Civil. $2^{a}$ edição. São Paulo: Malheiros, 2010, 581 p.

VERÇOSA, Haroldo Malheiros Duclerc; SZTAJN, Rachel. A Incompletude do Contrato de Sociedade. In: Revista de Direito Mercantil Industrial, Econômico e Financeiro, Ano XLII, vol. 131, 2003, pp. 7-20.

VON ADAMEK, Marcelo Vieira. Abuso de Minoria em Direito Societário (Abuso das Posições Subjetivas Minoritárias). Tese apresentada para a obtenção do grau de Doutor em Direito Comercial pela Faculdade de Direito da USP, sob a orientação do Prof. Dr. Erasmo Valladão Azevedo e Novaes França. 2010, 436 p. 
WALD, Arnoldo. Direito Civil: direito das obrigações e teoria geral dos contratos. 20ª edição. São Paulo: Saraiva, 2011, vol. 2, 381 p.

WALD, Arnoldo. Comentários ao Novo Código Civil. Livro II - Do Direito de Empresa. Coordenação de Sálvio de Figueiredo Teixeira. Rio de Janeiro: Forense, 2005, vol. XIV, 1021 p.

WALDEMAR FERREIRA, Tratado de Sociedades Mercantis. $5^{\text {a }}$ edição. Rio de Janeiro: Editora Nacional de Direito Ltda., vol. I, 1958, 573 p.

WIEDEMANN, Herbert, Gesellschaftsrecht I - Grundlagen (Excerto do Direito Societário I - Fundamentos). Munique: Editora Beck, 1980. Tradução de Erasmo Valladão A. e N. França. In: FRANÇA, Erasmo Valladão Azevedo e Novaes, Direito Societário Contemporâneo I. São Paulo: Quartier Latin do Brasil, 2009, 632 p.

\section{Legislação consultada}

Lei 556 , de 25 de junho de 1850

Lei 3.071 , de $1^{\circ}$ de janeiro de 1916

R.D. (Regio Decreto) n. 262, de 16 de março de 1942, que institui o Código Civil Italiano. Disponível em http://www.ligiera.com.br/estrangeira 9.html. Acesso em 01.11.2012.

Lei 6.404, de 15 de dezembro de 1976

Lei 10.406 , de 10 de janeiro de 2002 